\title{
A review of Caribbean Copepoda associated with reef-dwelling cnidarians, echinoderms and sponges
}

\author{
Oksana A. Korzhavina \\ Department of Invertebrate Zoology, Biological Faculty, Lomonosov Moscow State \\ University, Moscow, Russia
}

Bert W. Hoeksema

Taxonomy and Systematics Group, Naturalis Biodiversity Center, Leiden, The Netherlands

Groningen Institute for Evolutionary Life Sciences, University of Groningen, Groningen, The Netherlands

\section{Viatcheslav N. Ivanenko}

Department of Invertebrate Zoology, Biological Faculty, Lomonosov Moscow State University, Moscow, Russia Taxonomy and Systematics Group, Naturalis Biodiversity Center, Leiden, The Netherlands ivanenko.slava@gmail.com

\begin{abstract}
This review of copepod crustaceans associated with reef-dwelling cnidarians, sponges and echinoderms of the Greater Caribbean is based on published records, systematically arranged by the classification of symbiotic copepods and their hosts, sampling sites, coordinates, depth and date of sampling, literature sources, and three recent surveys (Cuba, St. Eustatius in the Eastern Caribbean and Curaçao in the Southern Caribbean). This resulted in totals of $53^{2}$ records of 115 species of symbiotic copepods (47 genera, 17 families, three orders) hosted by 80 species of invertebrates, representing scleractinians $(47 \%)$, octocorals $(9 \%)$, echinoderms $(3 \%)$, and sponges (1\%). Among ten Caribbean ecoregions, the Greater Antilles (with 64 species of symbiotic copepods) as well as the Southern and Eastern Caribbean (with 46 and 17 species of copepods, respectively) are the most studied and best represented, whereas only six species of copepods are known from Bermuda, one from Southwestern Caribbean and none from the Gulf of Mexico. The absence of poecilostomatoid copepods (Anchimolgidae, Rhynchomolgidae and Xarifidae) on Caribbean stony corals as noted by Stock (1988) is confirmed. The results indicate that the diversity and ecology of Caribbean symbiotic copepods are still poorly investigated.
\end{abstract}




\section{Keywords}

Crustacea - Cnidaria - Echinodermata - Porifera - reefs, diversity - symbiosis - parasitism

\section{Introduction}

Symbiotic copepods are a widespread, numerous and diverse group of crustaceans living in association (parasitism, commensalism, mutualism) with other marine animals (Gotto, 1979, 1993; Humes, 1985a, 1994; Ho, 2001). At least one third of all known copepods are symbionts of marine fish and invertebrates. Symbiotic copepods are the most diverse in the tropics, and only a small number of their potential marine invertebrate hosts has been explored so far $(1.14 \%$ according to Humes, 1994). A high degree of endemism as well as a remarkable difference in taxonomic composition of copepods living in a poorly studied symbiosis with Caribbean stony corals is noticed in comparison with the Indo-Pacific (Stock, 1988). The paucity of knowledge of symbiotic copepods of the Greater Caribbean region has repeatedly been noted (Stock, 1973, 1975a, 1987, 1988; Humes \& Hendler, 1972; Herriott \& Immermann, 1979; Grygier, 1980; Ivanenko et al., 2017).

The first study of symbiotic copepods living on cnidarians, echinoderms and sponges of the Greater Caribbean was conducted by Edwards (1891), who discovered Diogenidium nasutum (fig. 1c), living on the sea cucumber Holothuria scabra, in the Bahamas (species authorities in tables 1-2). Taxonomic studies of the Caribbean symbiotic copepods were continued by a number of researchers, who described large numbers of new species, as reviewed by Gotto (1993). A number of copepods representing two families (the ectosymbiotic Asterocheridae and the endoparasitic Corallovexiidae) have been found living on and in stony corals (Hoeksema et al., 2017b). Very few are reports have been published about the Asterocheridae living and usually abundant on sponges (Stock \& Kleeton, 1964; Stock, 1967; Boxshall \& Huys, 1994; Kim, 2010; Varela et al., 2005b, 2007a, b, 2008; Varela, 2010a, b, 2012). Twelve families of copepods have been reported on diverse Caribbean echinoderms (Edwards, 1891; Emson \& Mladenov, 1987; Emson et al., 1985; Hendler \& Kim, 2010; Humes \& Hendler, 1972, 1999; Humes \& Ho, 1970, 1971; Humes \& Stock, 1973; Humes, 1969a, 1998, 2000; Kim, 2009, 2010; Stock \& Gooding, 1986; Stock \& Humes, 1995; Stock et al., 1962, 1963a, b; Stock, 1968; Varela et al., 2003, 2005b, 2008; Varela, 2010a, 2011a). Most of these studies on Caribbean invertebrateassociated copepods are from the last century and only 19 of them have been published since 2000 (Humes, 2000; Varela et al., 2003, 2005a, b, 2007a, b, 2008; Varela \& Lalana, 2007; Kim, 2009, 2010; Hendler \& Kim, 2010; Varela, 2010a, b, 2011a, b, 2012; Ivanenko et al., 2017; Shelyakin et al., 2018; Garcia-Hernandez et al., 2019).

Caribbean reef corals are under threat from climate change and local impacts (Carpenter et al., 2008; Hughes et al., 2017) and some symbiotic (including parasitic) copepods potentially may have an impact on the state of corals and other invertebrate hosts (Stock, 1975a; Butter, 1979; Herriott \& Immermann, 1979; Burke \& Maidens, 2004; Ivanenko et al., 2017; Shelyakin et al., 2018). Despite a long history of marine biodiversity research in the Caribbean, our knowledge of microscopic symbiotic copepods does not satisfy the needs for defining priorities in conservation and the development of management plans (Miloslavich et al., 2010; Zeppilli at al., 2015, 2018). The goal of our review is to analyze all published data on copepods living in symbiosis with the Caribbean reef-dwelling anthozoans, echinoderms and ssponges asmimportant/strueturab $\odot: 09$ AM 

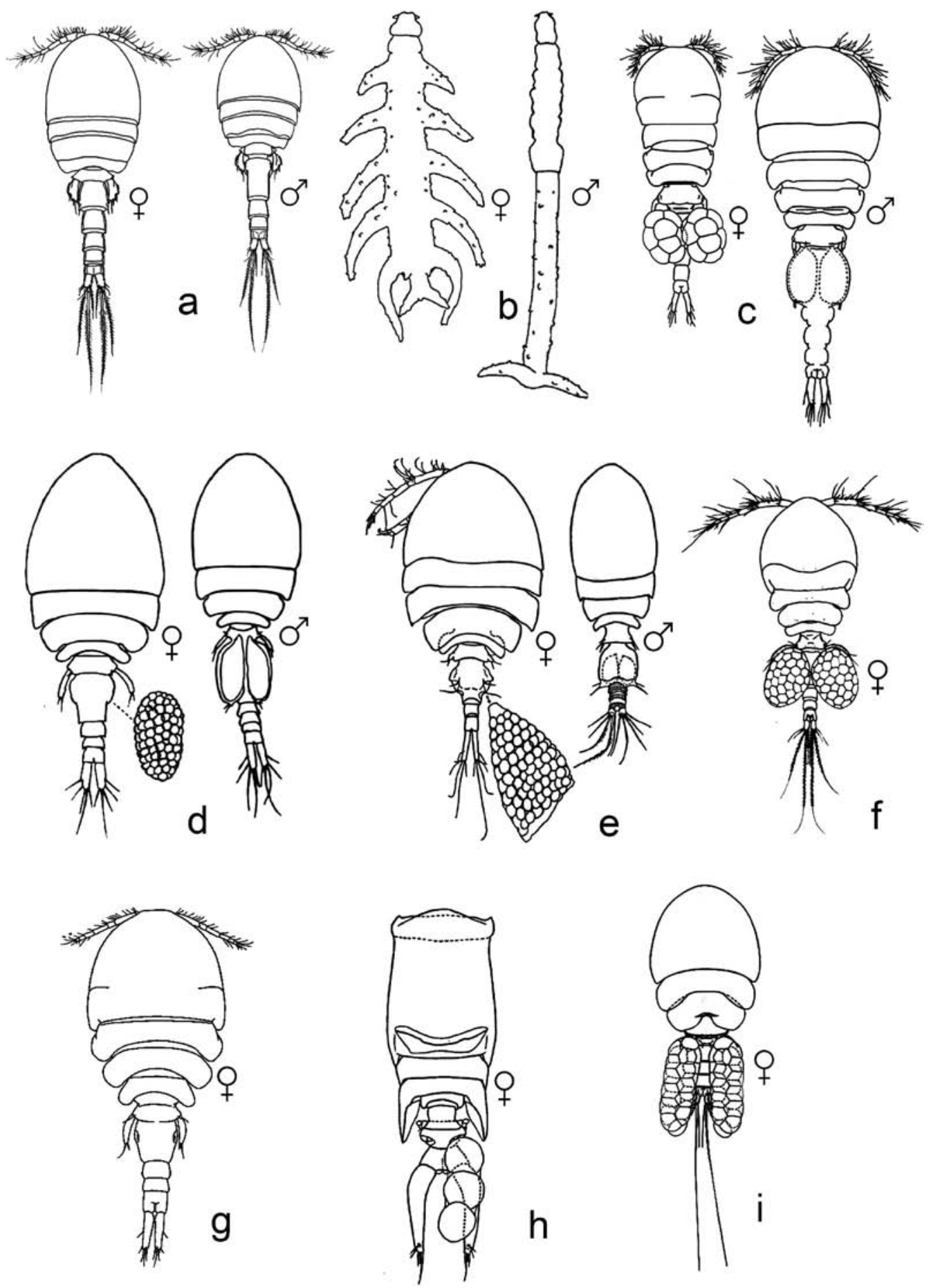

FIGURE 1 Poecilostomatoid Cyclopoida, dorsal view. a - Hemicyclops columnaris (Clausidiidae), b - Corallovexia similis (Corallovexiidae), c - Diogenidium nasutum (Lichomolgidae), d-Macrochiron echinicolum (Macrochironidae), $\mathrm{e}$ - Pseudanthessius deficiens (Pseudanthessiidae), $\mathrm{f}$ - Doridicola astrophyticus (Rhynchomolgidae), g - Eupolymniphilus occidentalis Kim, 2009 (Sabelliphilidae), h - Meomicola amplectans, i - Presynaptiphilus amphiopli (Synapticolidae). After Stock et al. (1963b), Humes \& Ho

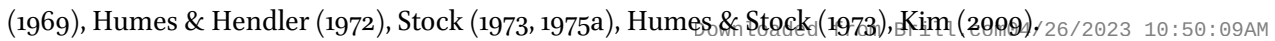


and functional components of Caribbean coral reefs in order to identify the least-studied ecoregions and groups of hosts as well as to identify directions for further research.

\section{Characteristics of the Greater Caribbean}

The Greater Caribbean (The Caribbean s.l.) in the present review consists of the Caribbean Sea plus the Gulf of Mexico and Bermuda (Spalding et al., 2007; Hoeksema et al., 2017a). The Caribbean Sea (Caribbean s.s.) is a large semi-enclosed sea of the western Atlantic Ocean with clear and warm water $\left(22-29^{\circ} \mathrm{C}\right)$ and low tidal amplitude ( $0.4 \mathrm{~m})$ (Kinder et al., 1985). The Caribbean is enclosed by the land masses of Central and South America (Brazil) from the west and south. It is separated by island arcs of the Great and Lesser Antilles in the north and east (Bayer, 1961; Spalding et al., 2004; Alvarado, 2011). The Caribbean is a unique biogeographic region with a number of endemic species (Rivera-Monroy et al., 2004; Alvarado, 2011). It is recognized as a global marine biodiversity hot spot and an important biogeographic coral reef province (Spalding et al., 2001; Roberts et al., 2002; Miloslavich et al., 2010; Alvarado, 2011). The Greater Caribbean includes ten marine ecoregions: Northern Gulf of Mexico, Southern Gulf of Mexico, Floridian, Western Caribbean, Greater Antillean, Southwestern Caribbean, Southern Caribbean, Eastern Caribbean, Bahamian, and Bermudian (Burke \& Maidens, 2004; Spalding et al., 2007; Hoeksema et al., 2017a). The Bahamian and Bermudian are adjacent to the temperate northwestern Atlantic. The marine ecoregions of the Southern and Eastern Caribbean are affected by biota from adjacent Brazilian waters (Alvarado, 2011). The Gulf of Mexico has colder and more isolated water, which is relatively poor in species (Felder \& Camp, 2009).

\section{Material}

The data are combined in the originally designed Database on Caribbean copepod crustaceans associated with reef-dwelling corals, echinoderms and sponges. This database includes five main tables: Hosts, Symbionts, Samples, Sites, and Publications linked with each other and two combined tables Literature Records and Sample Records; each record contains data on the taxonomy of the host and its symbiont, the references to unique records in the World of Copepods (Walter \& Boxshall, 2019), the number of associates per host, the nature of the association, the name and coordinates of the collection site, the depth and the date of collection, as well as their reference (Korzhavina \& Ivanenko, 2019). In addition, data on samples of symbiotic copepods and their hosts collected at St. Eustatius (in 2015, with 104 samples), Curaçao (in 2017, with 77 samples) and Cuba (in 2019, with 56 samples) preserved in $96 \%$ ethanol and including underwater photographs have been added to the table Sample Records.

\section{Results and discussion}

The database includes 532 records from 154 localities and 54 references published since 1891 (Edwards, 1891). There are 115 species of copepods (47 genera, 17 families, 3 orders) found in symbiosis with 80 invertebrate host species representing $5^{8}$ genera, 39 families, 22 orders and 7 classes of corals, sponges and echinoderms (figs. 1-7, tables 1-7). Only one species of copepods, the poecilostomatoid cyclopoid Hemicyclops columnaris (syn Hemicyclops geminatus) was found in the area under consideration (Bahamas, Barbados, Curaçao, and Jamaica, associated with a burrowing ghost shrimp, a sponge, an ophiuroid, hermit crabs) and on the Pacific coast of Panama (on a stony 


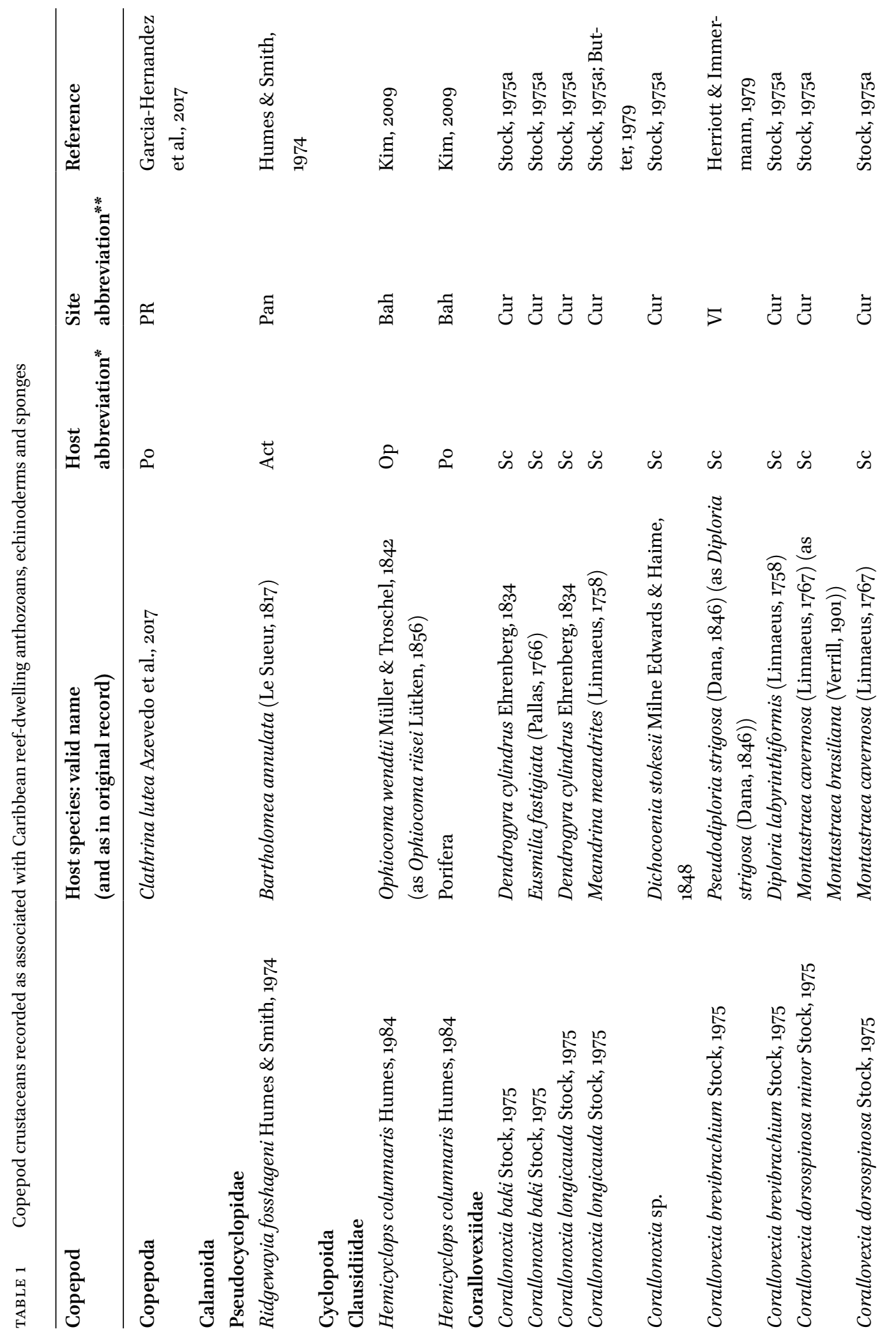




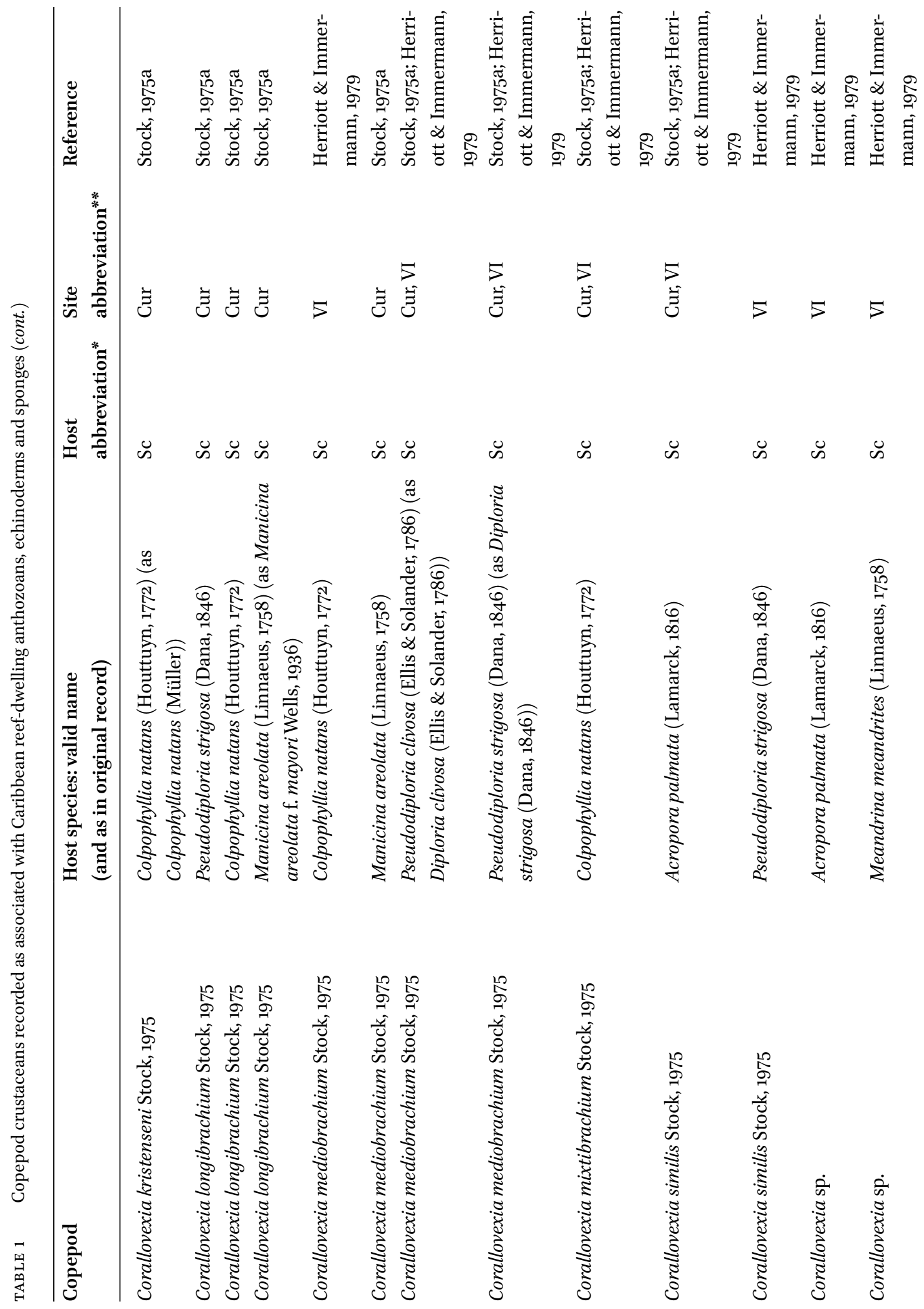




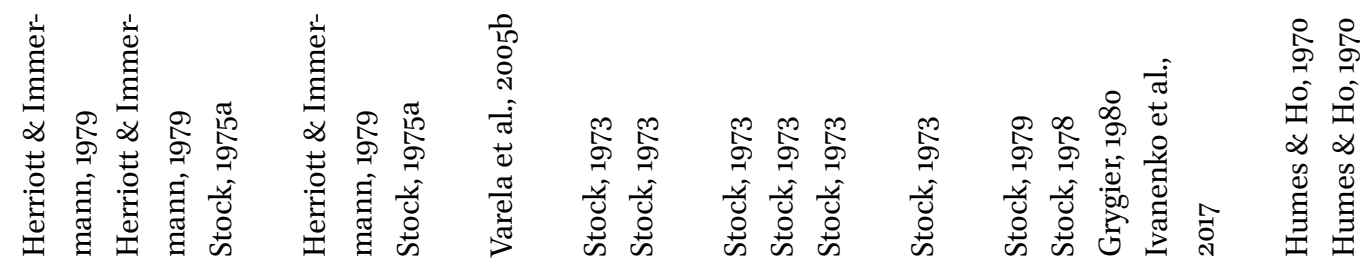

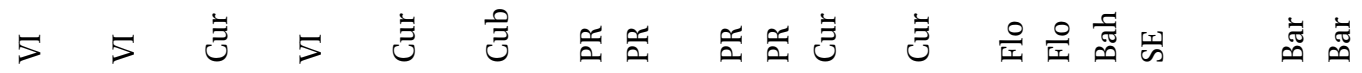

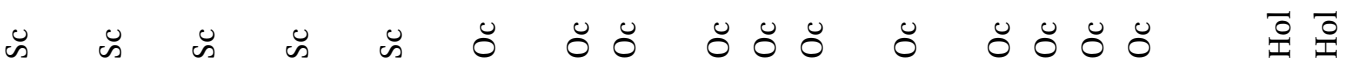

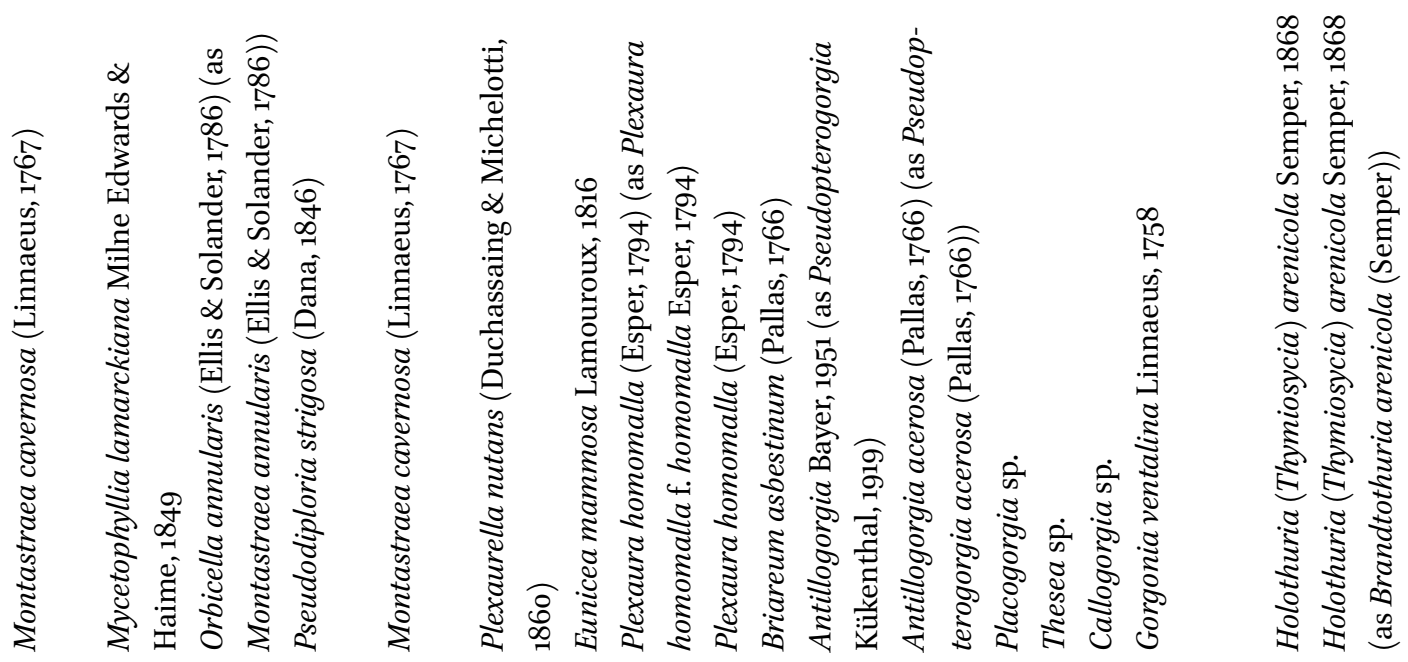

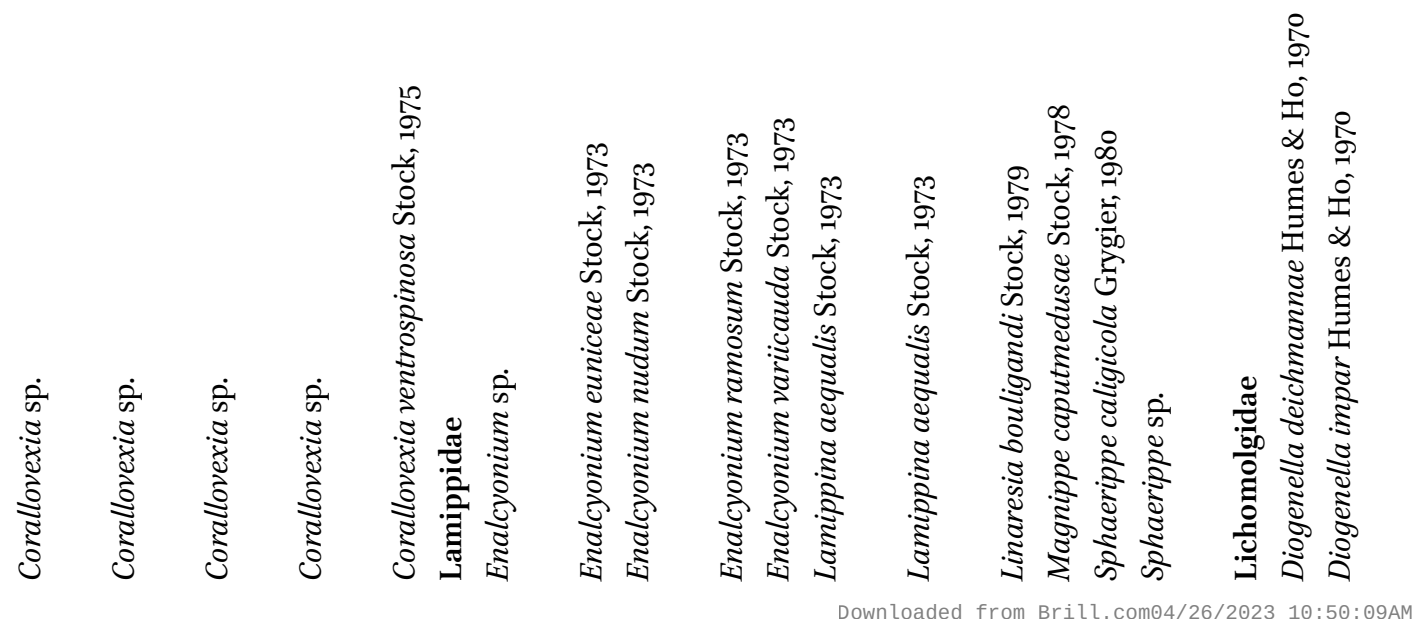




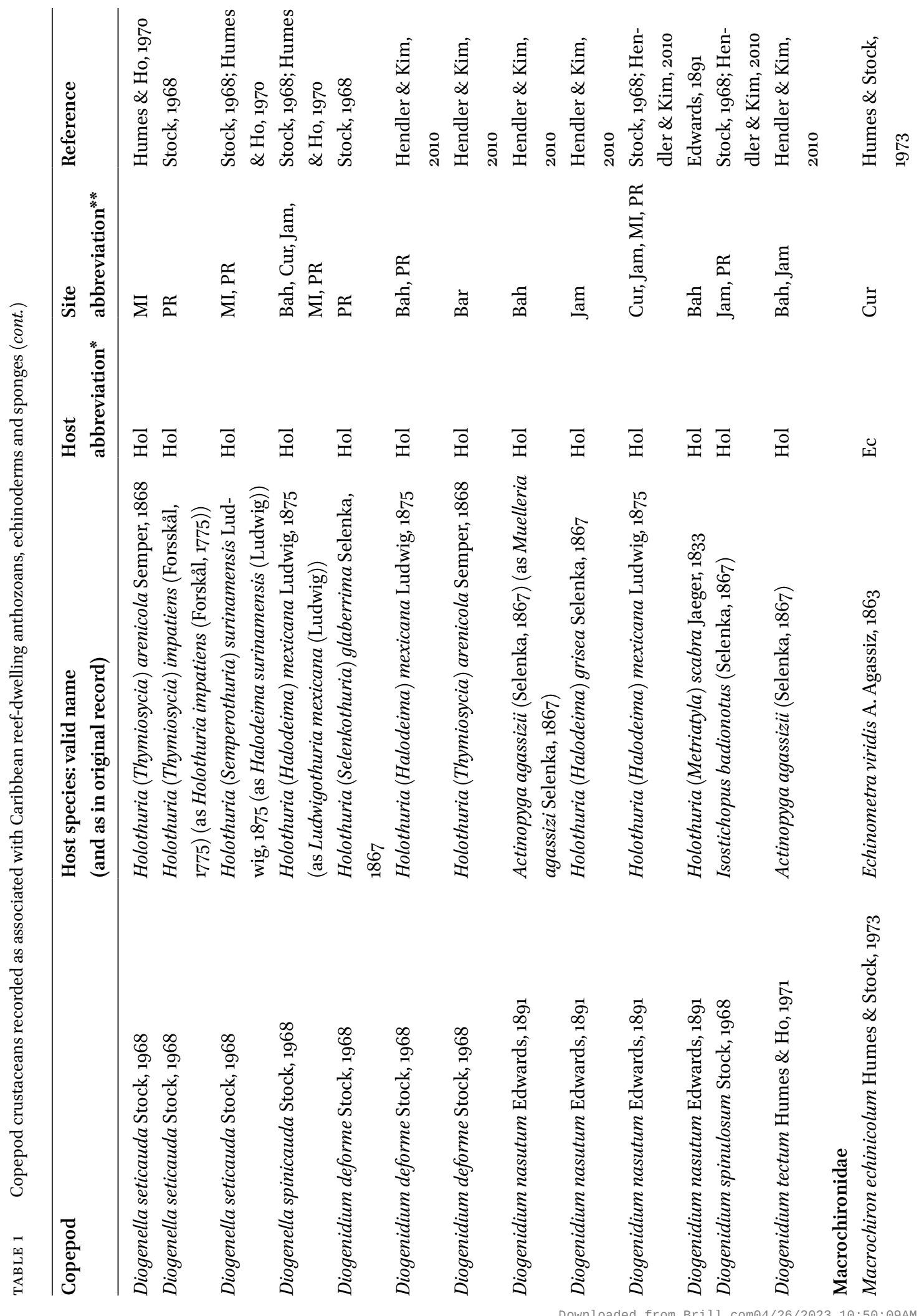



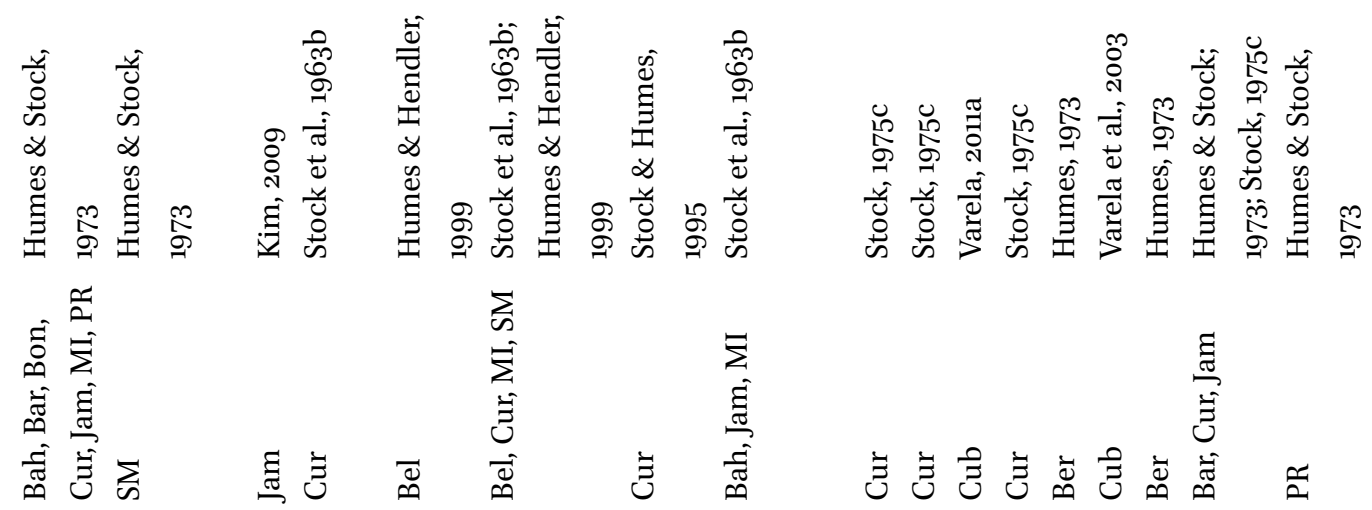

y
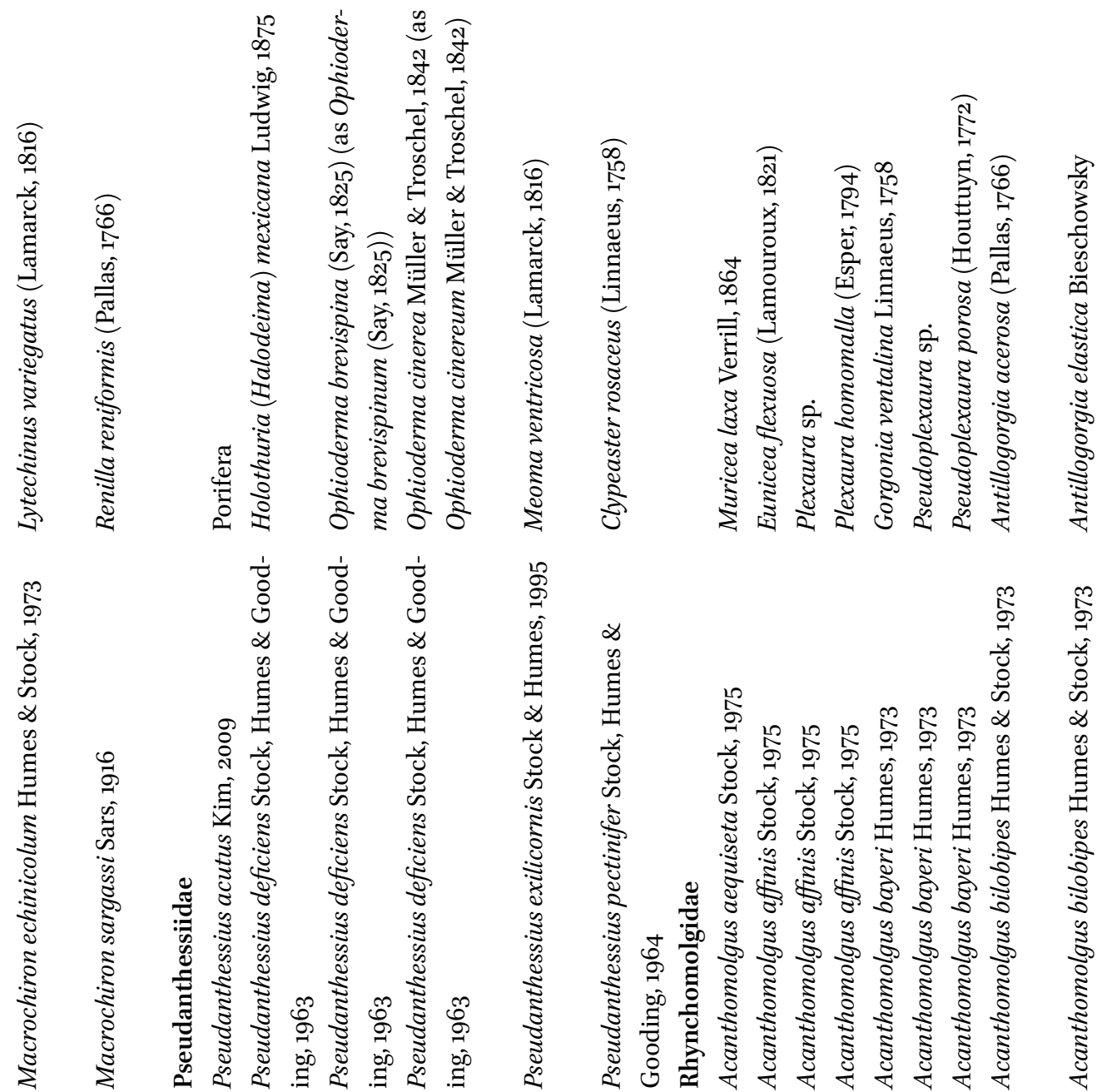


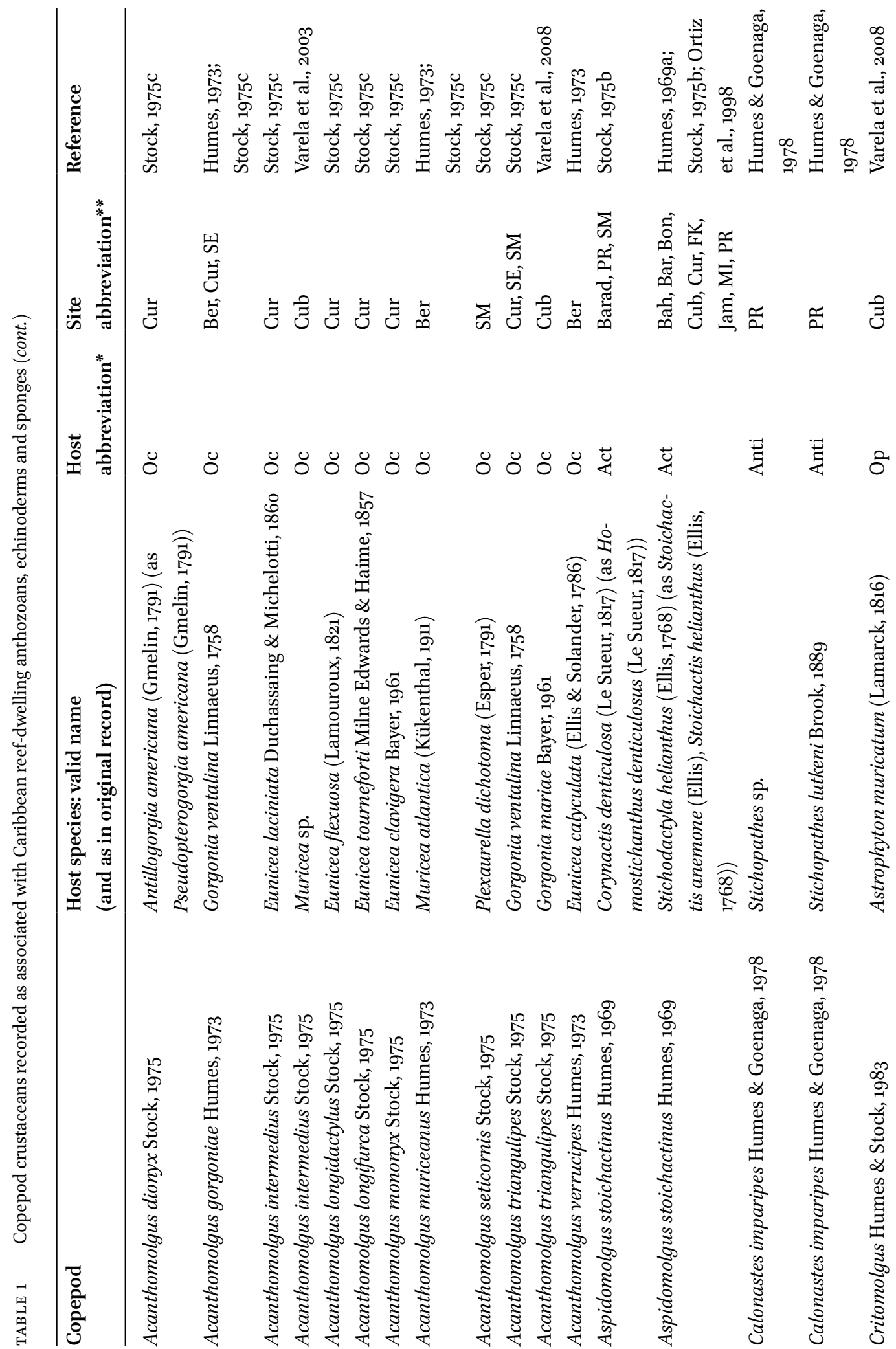




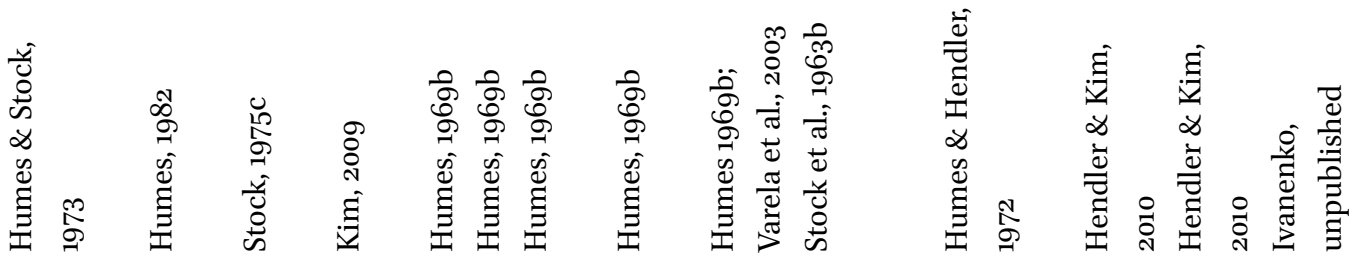

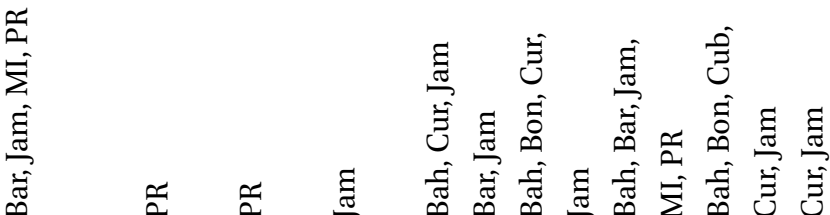

o̊ 䒺

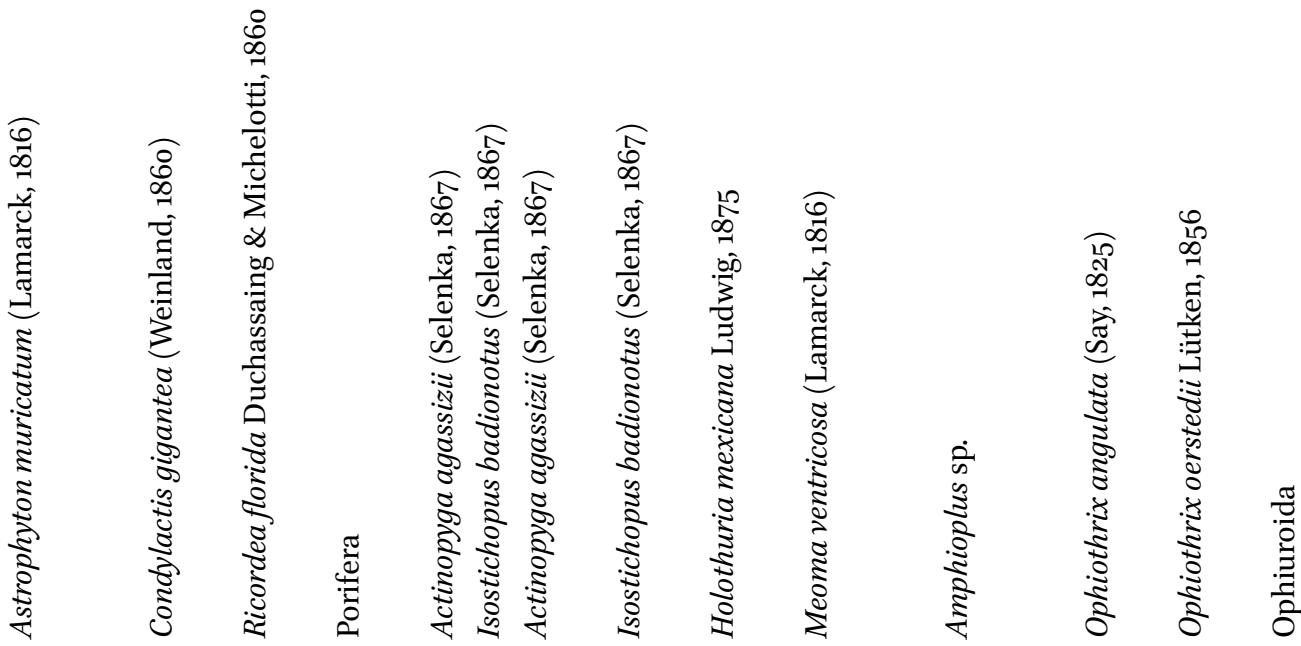

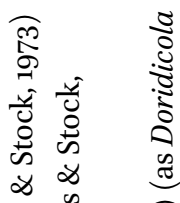

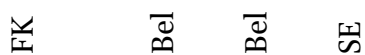

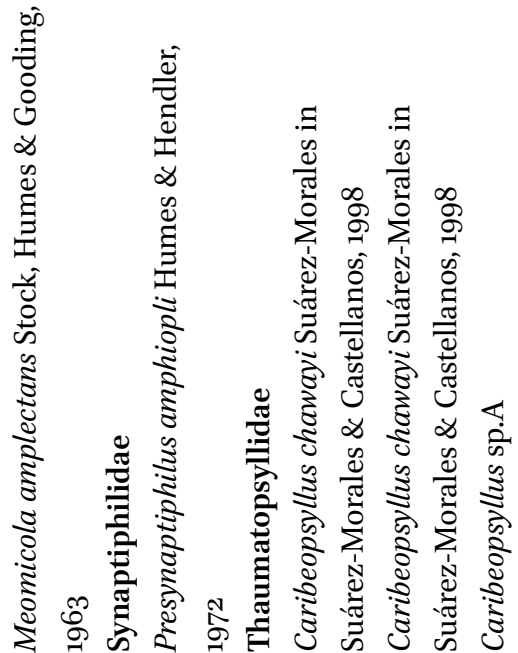




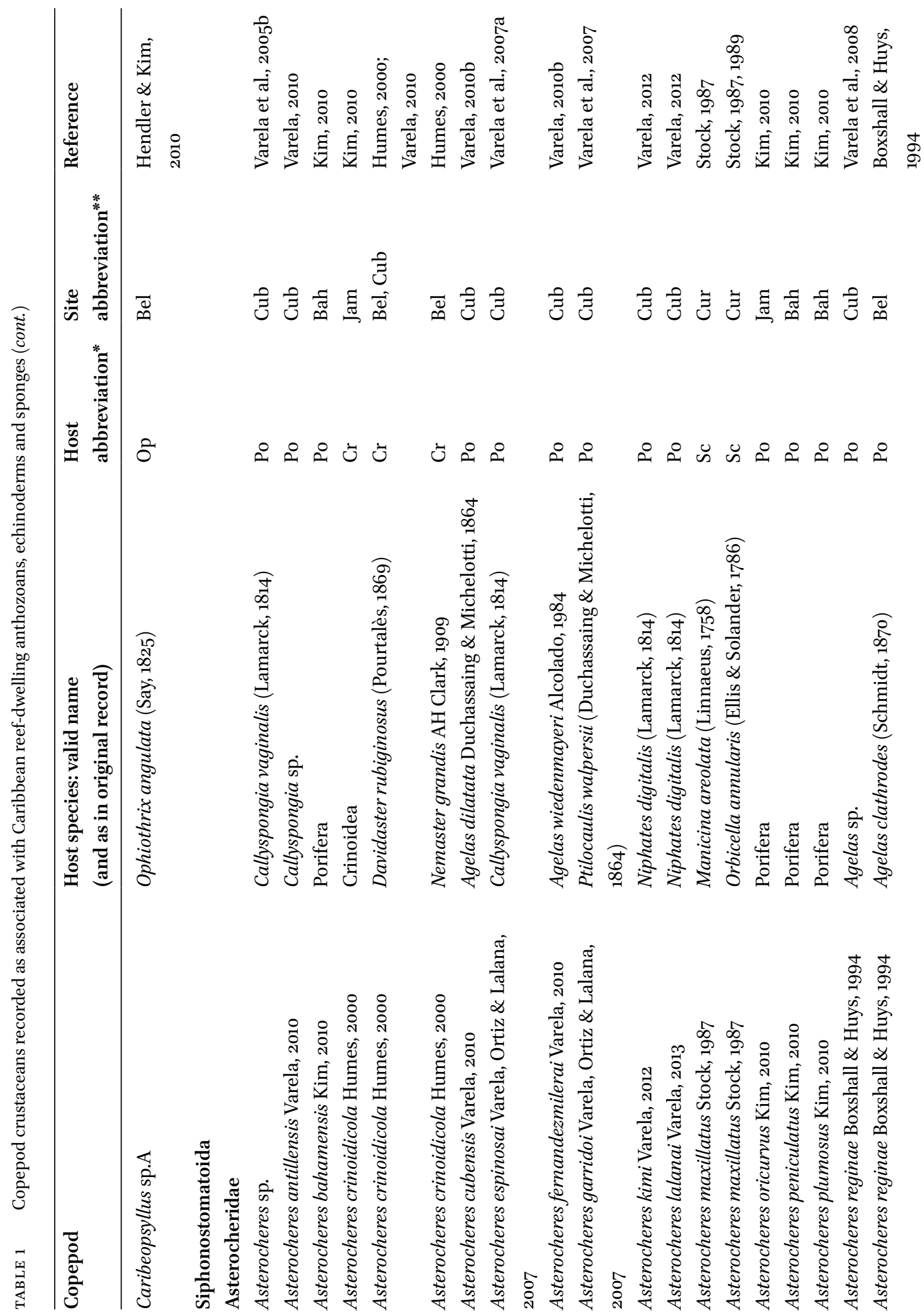




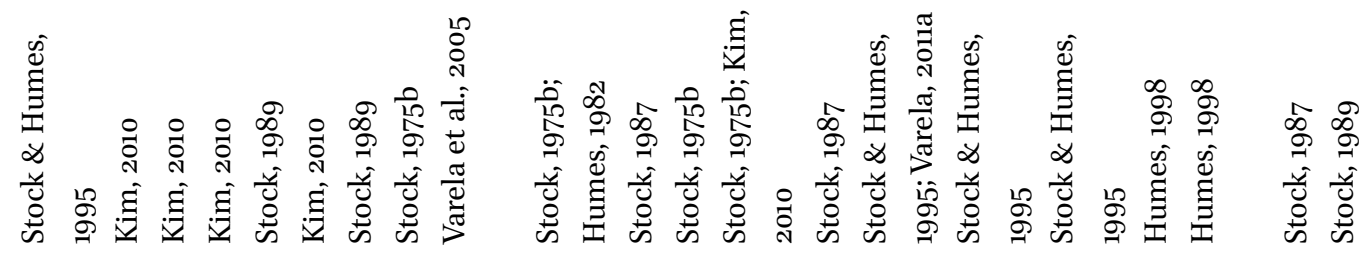

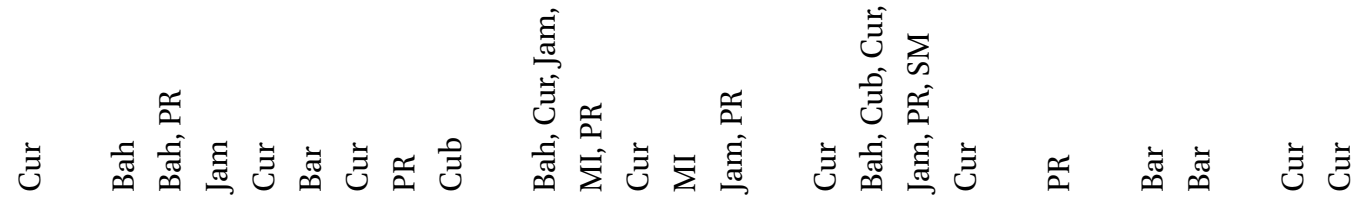

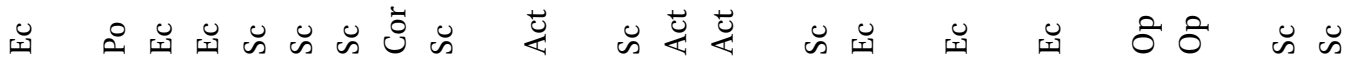

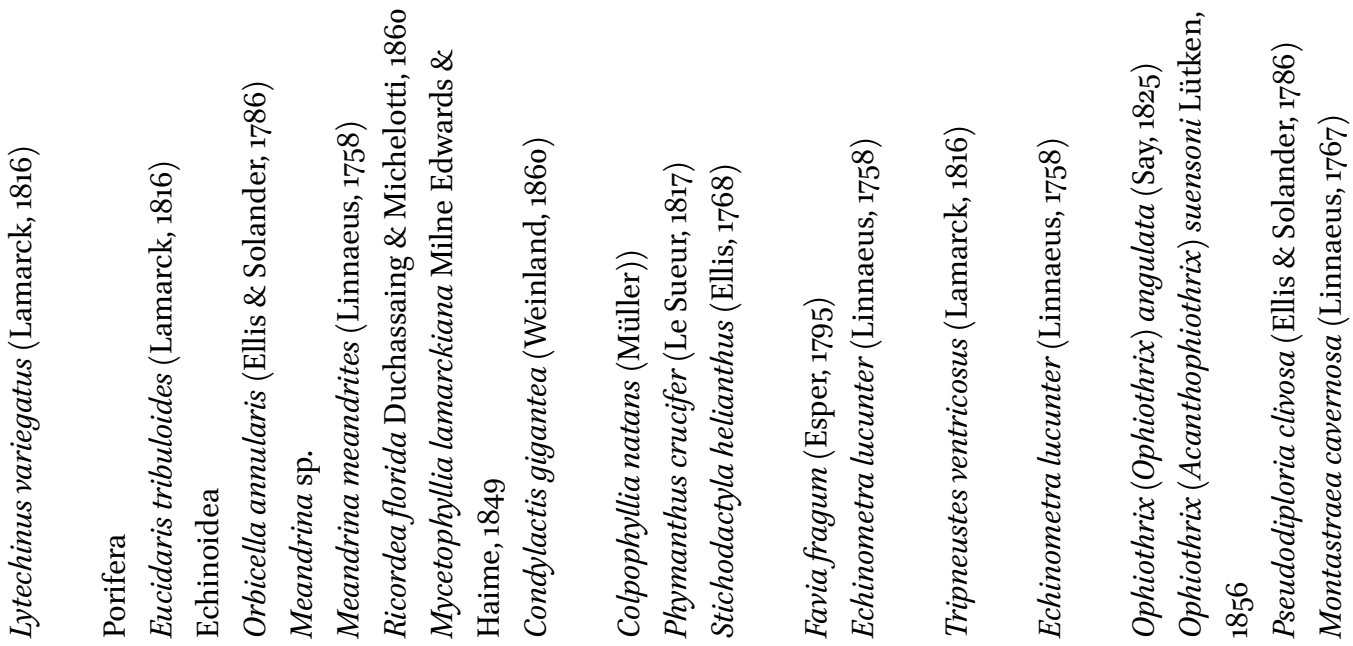

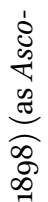

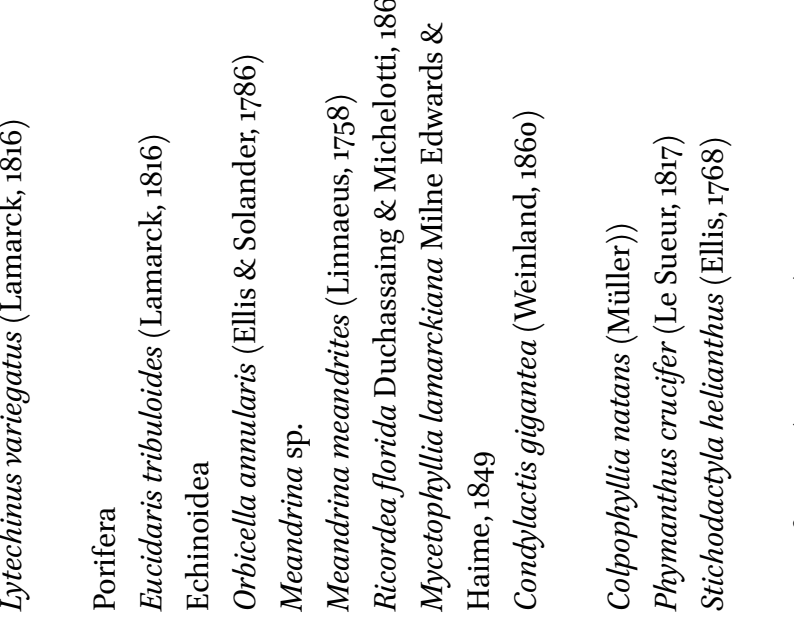

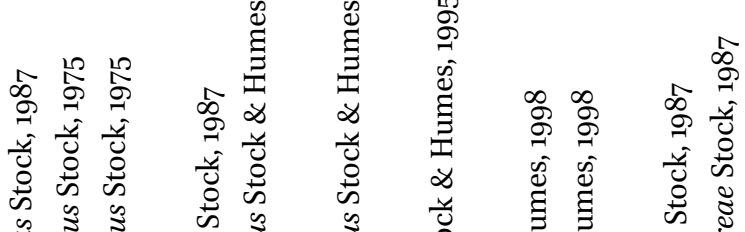

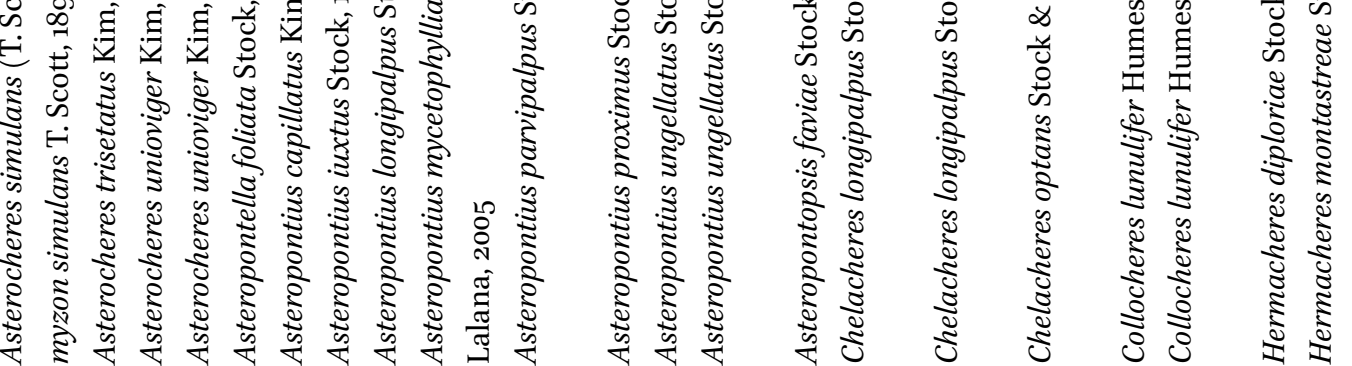




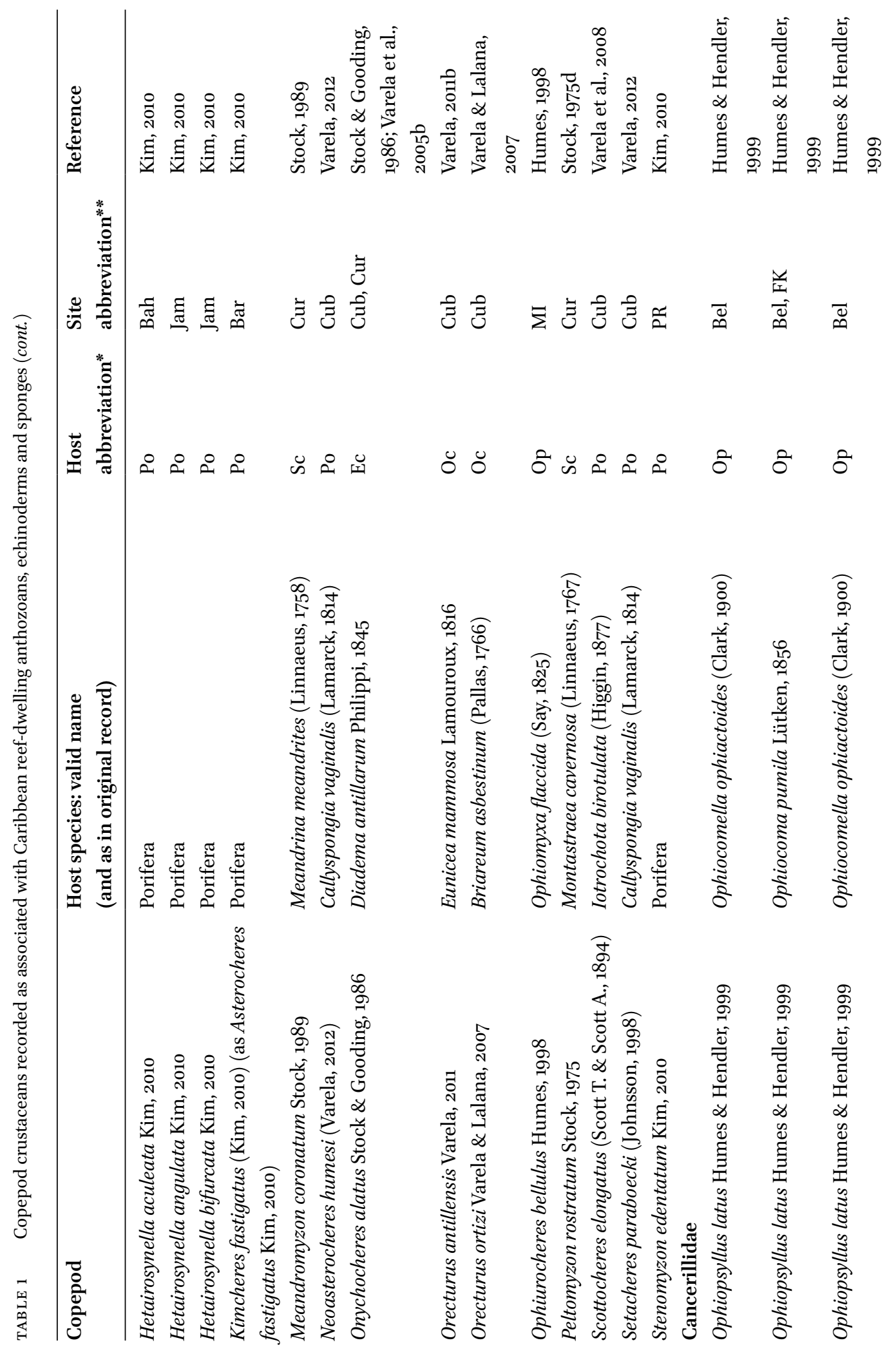




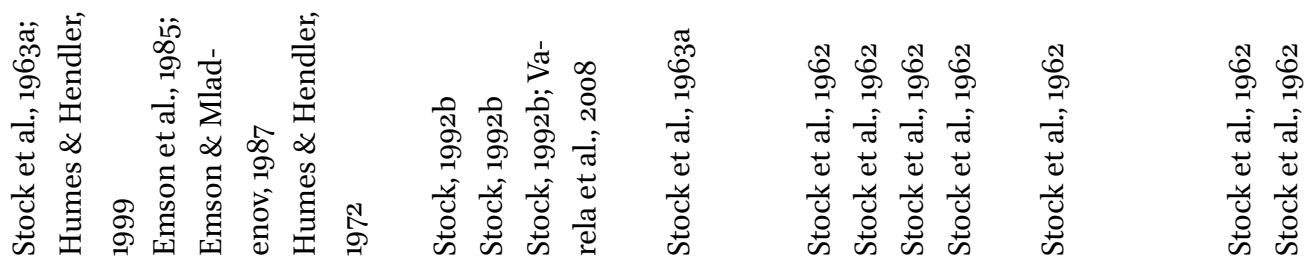

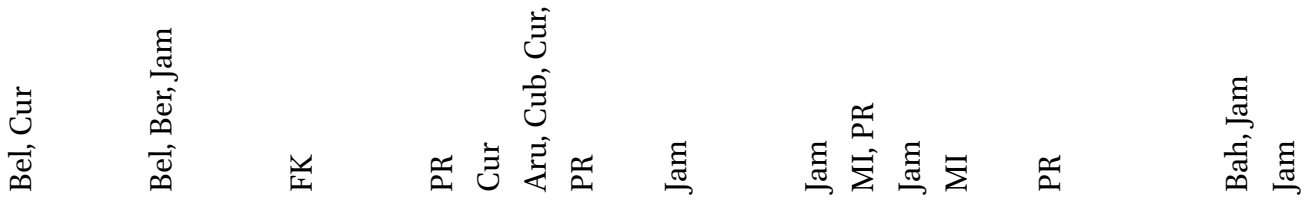

o̊

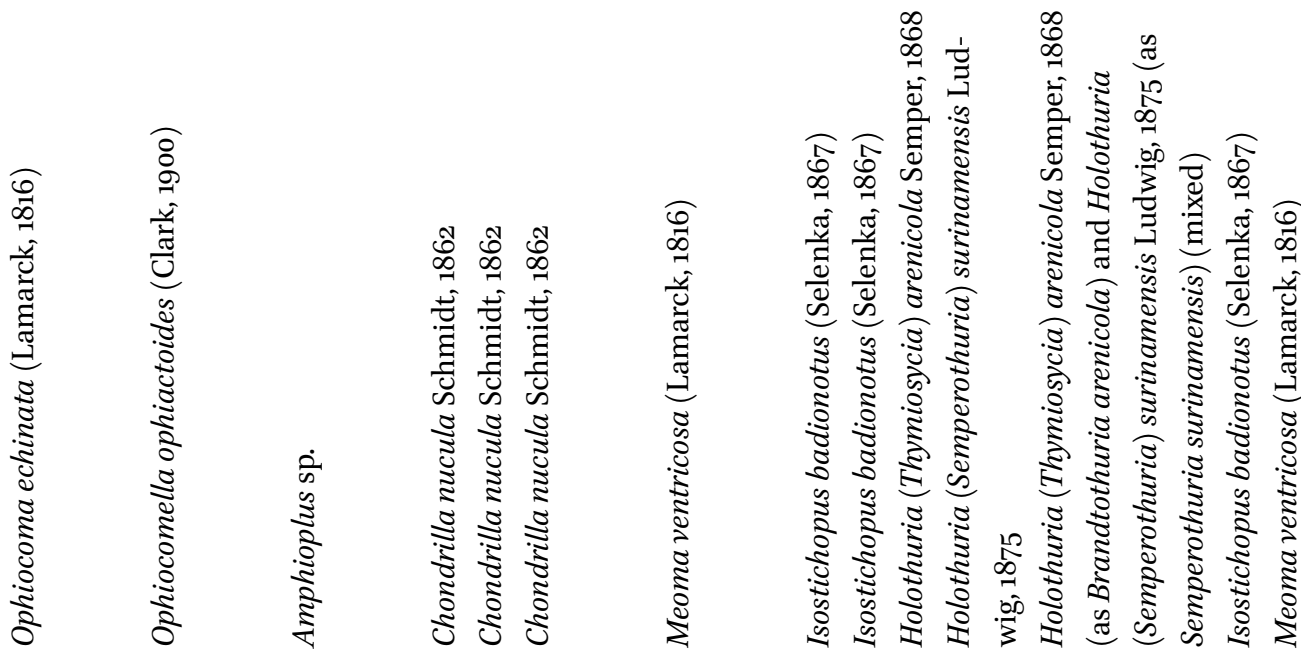

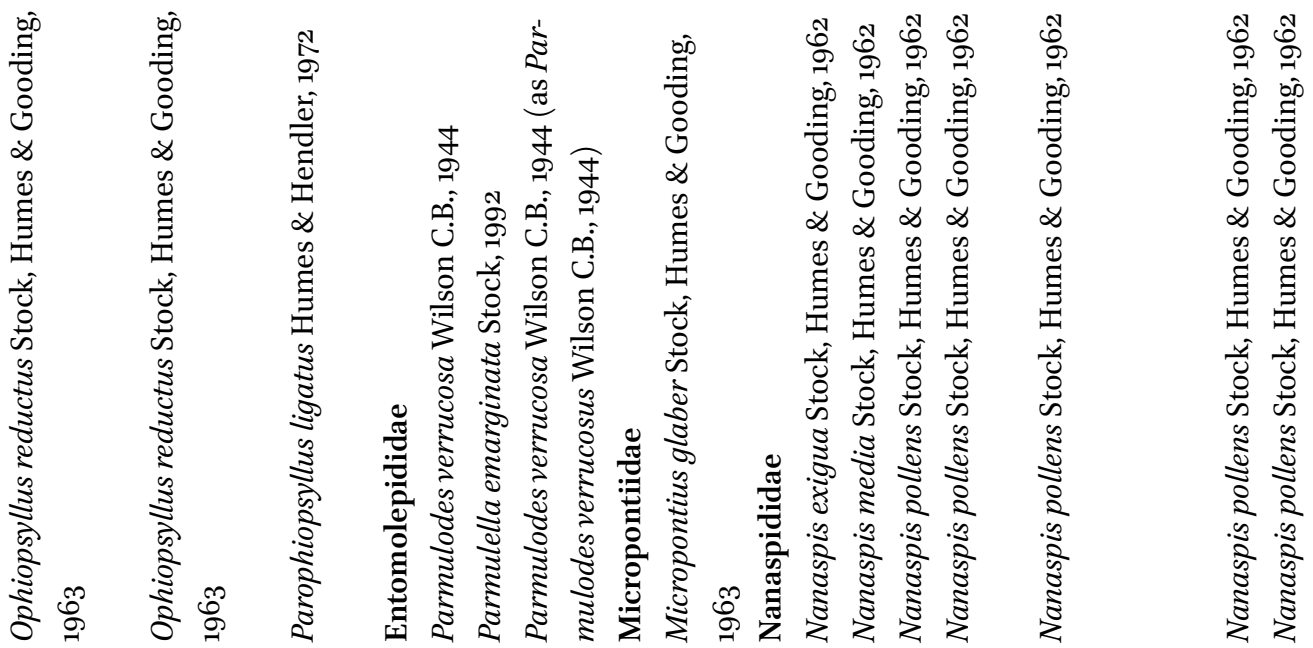




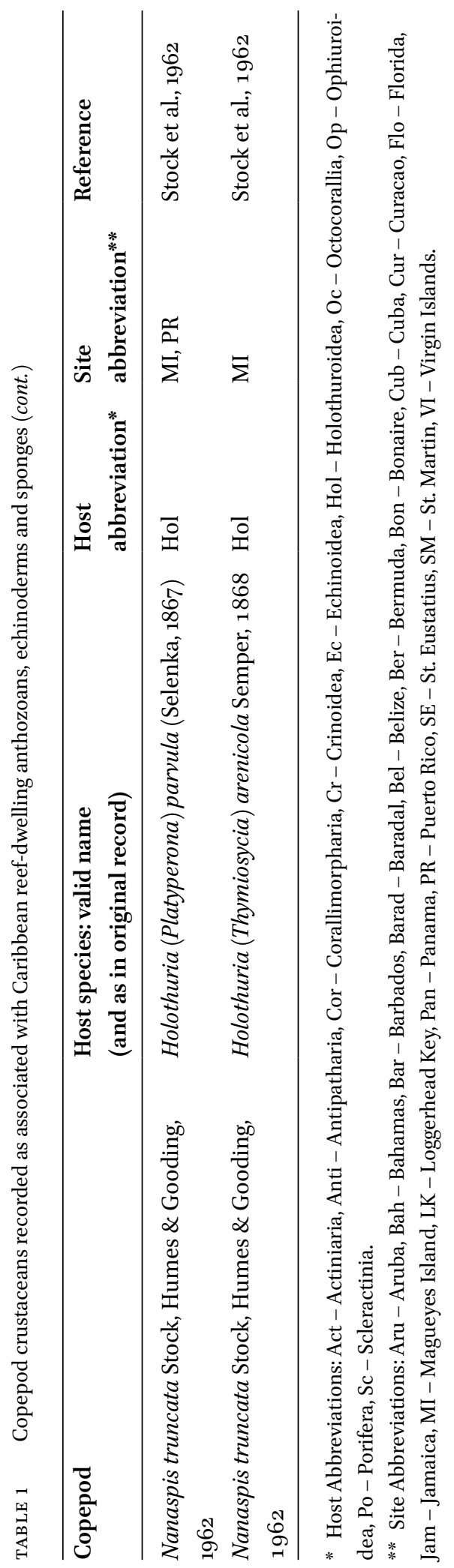



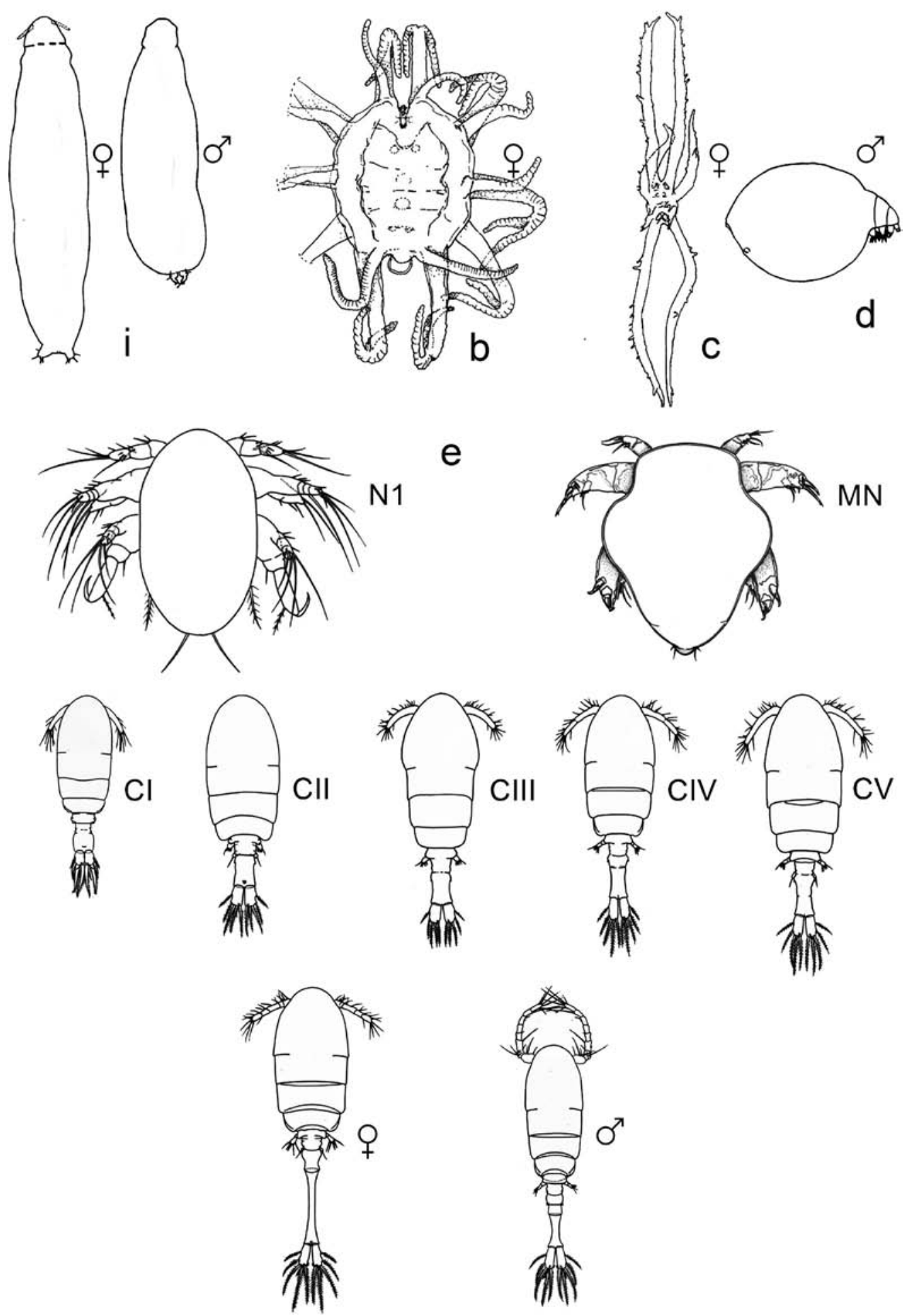

FIGURE 2 Cyclopoida. Lamippidae (a-d): a - Enalcyonium nudum, dorsal view; b - Linaresia bouligandi, dorsal view; c - Magnippe caputmedusae, ventral view; d - Sphaerippe caligicola, lateral view. Thaumatopsyl-

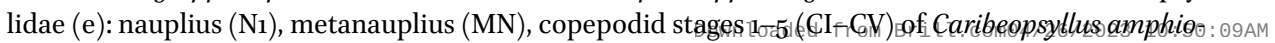
diae, dorsal view. After Stock (1973, 1978, 1979), Grygier (1980), Dojiri et al. (2008). 


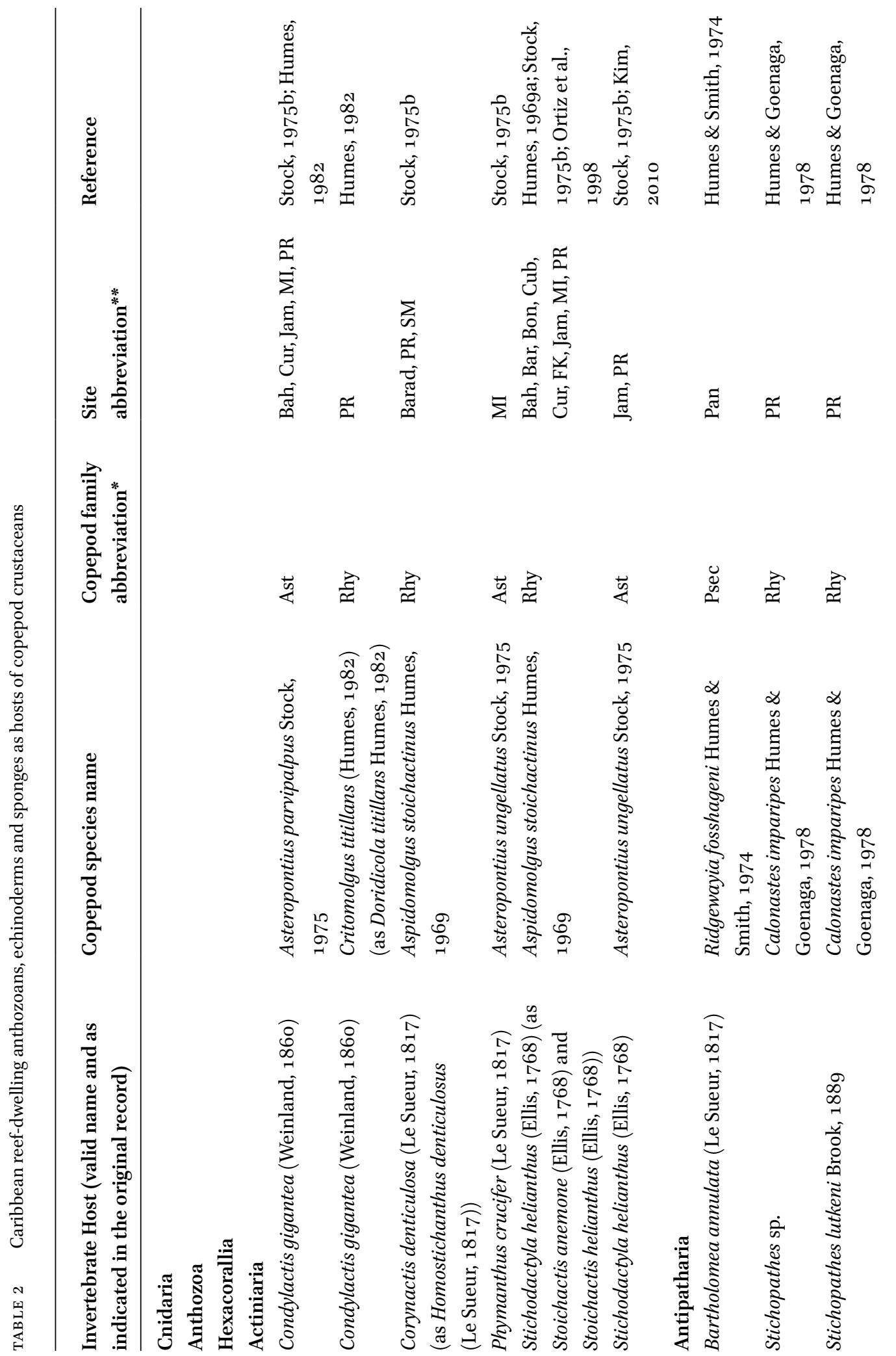




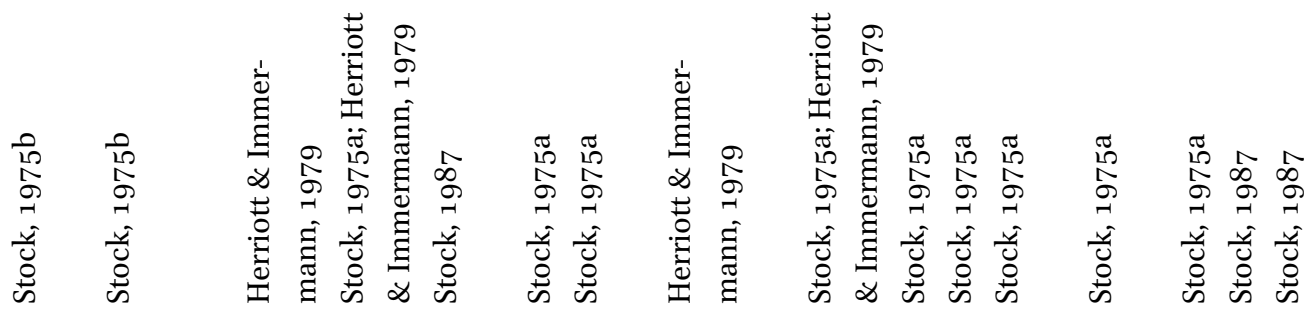

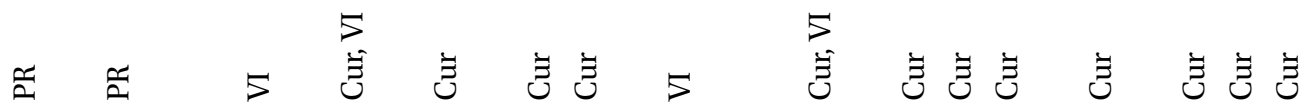

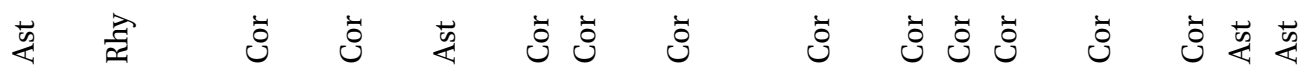

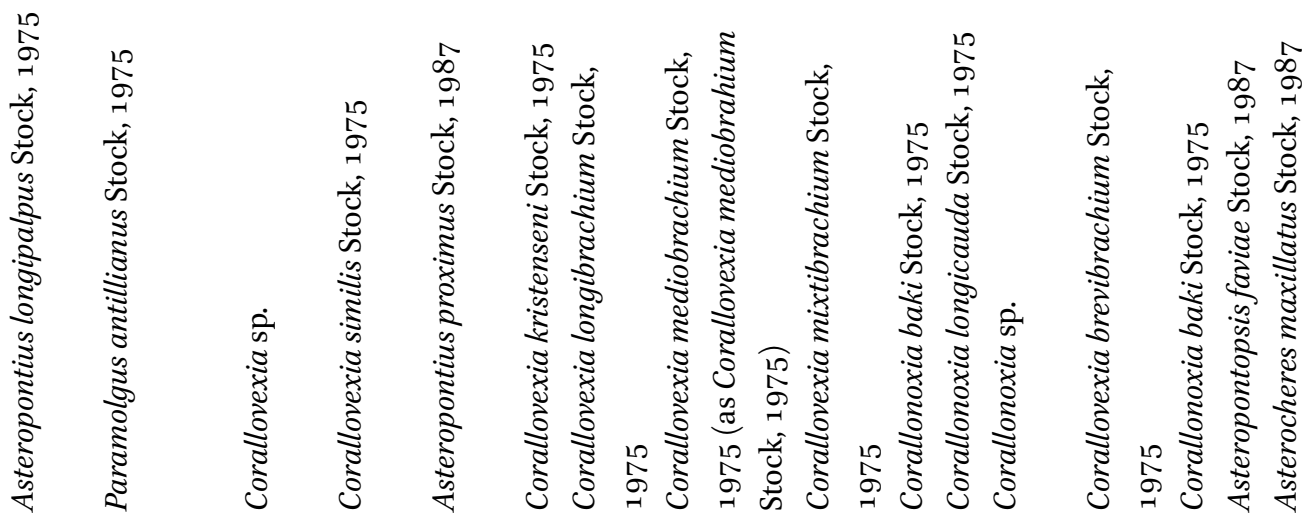

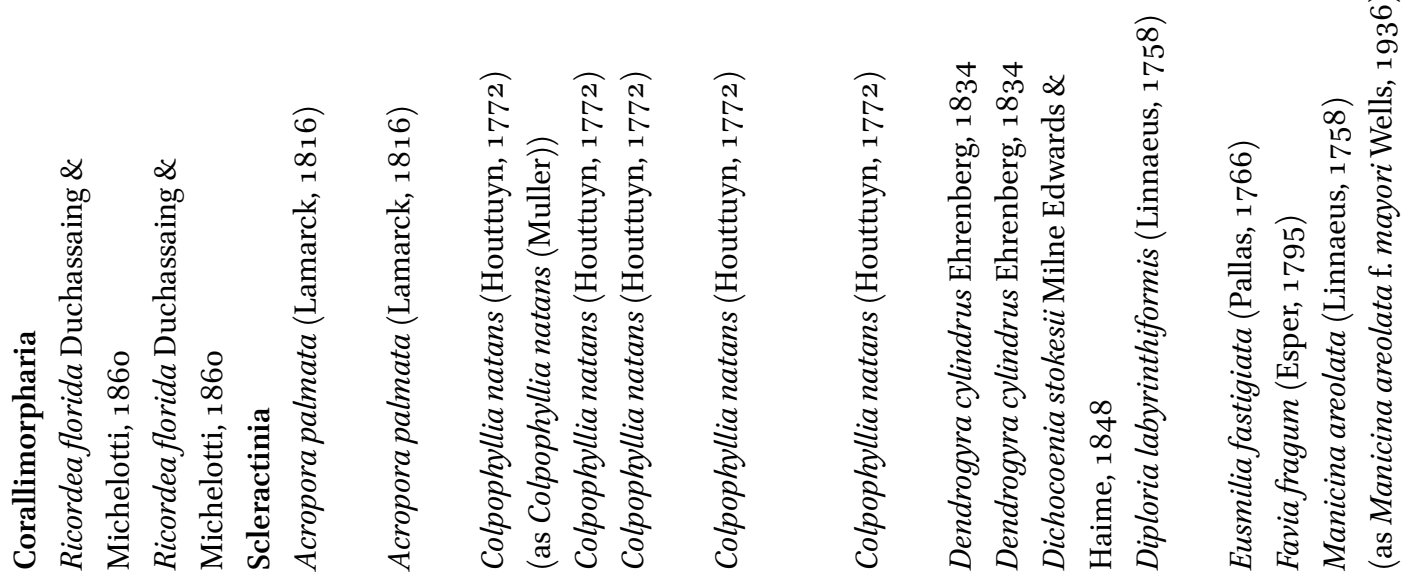




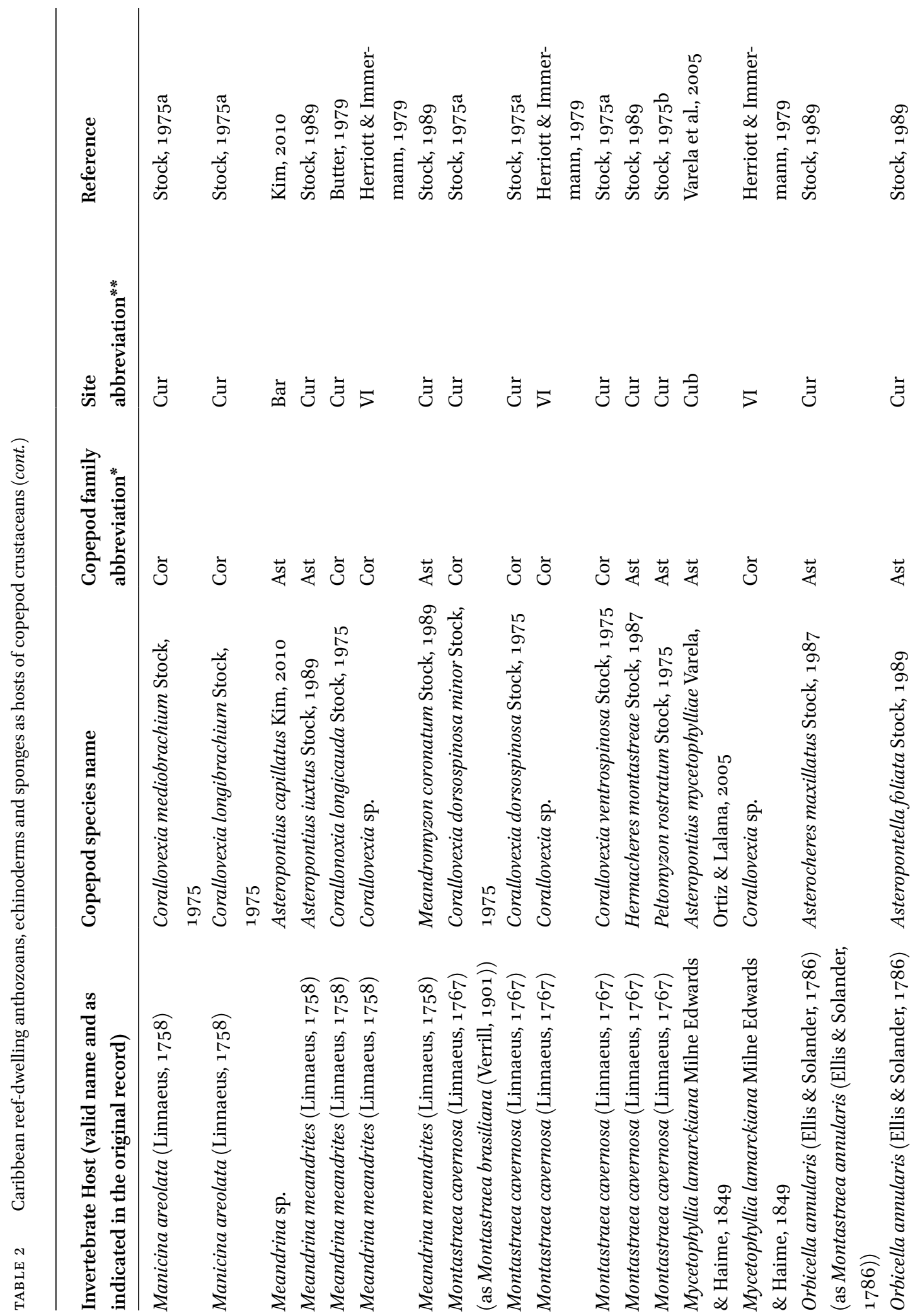




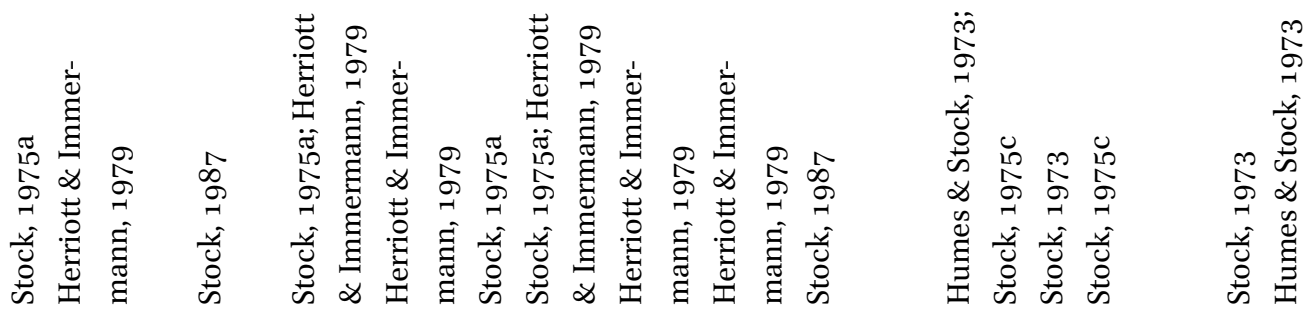

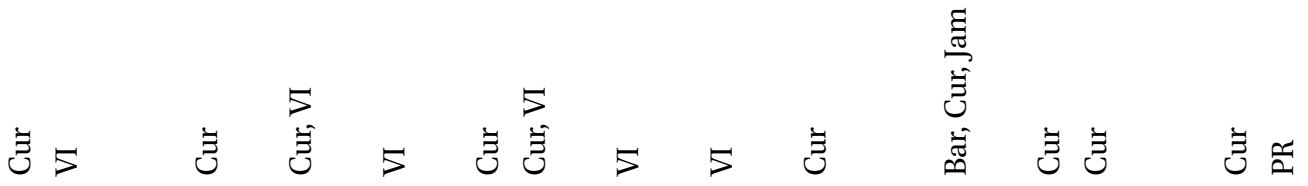

苟

के

㔯

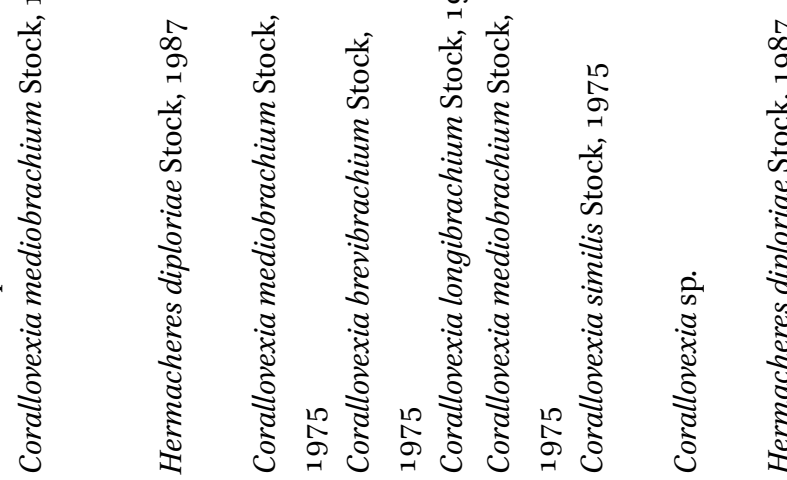

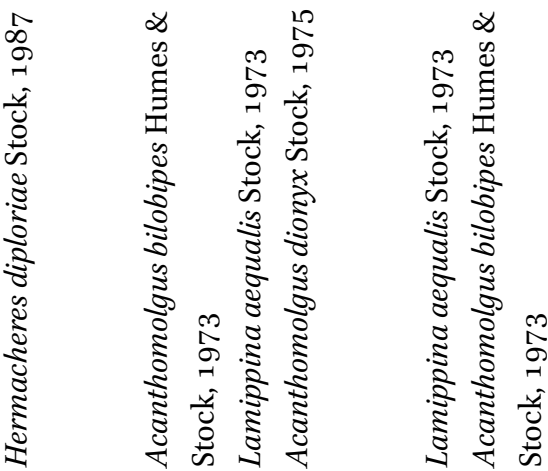

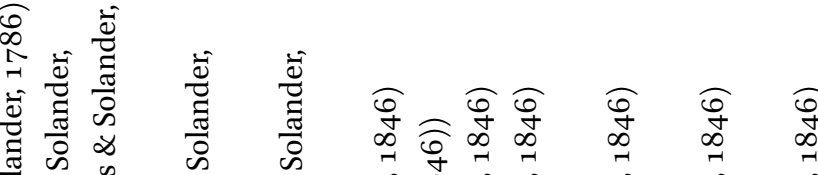

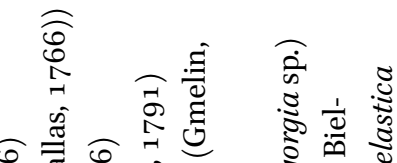

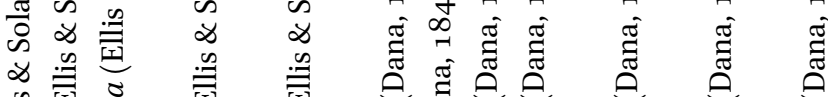

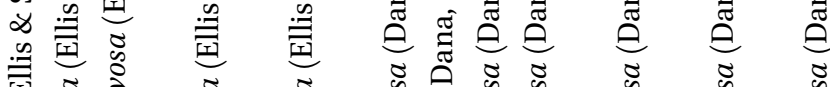

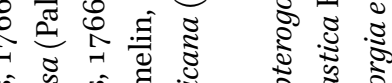

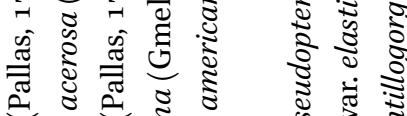

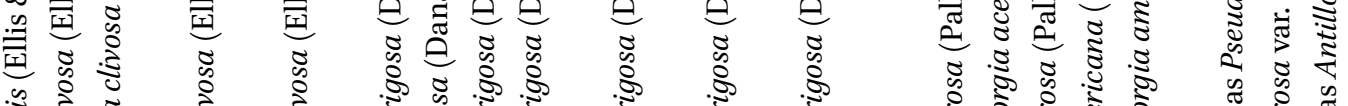

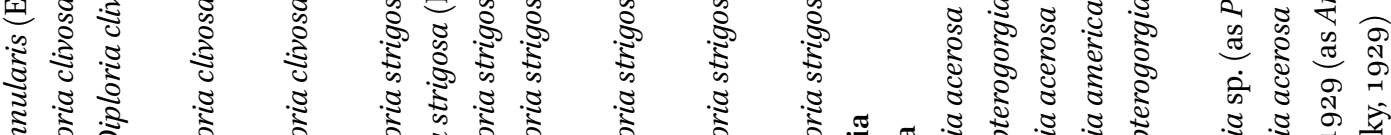

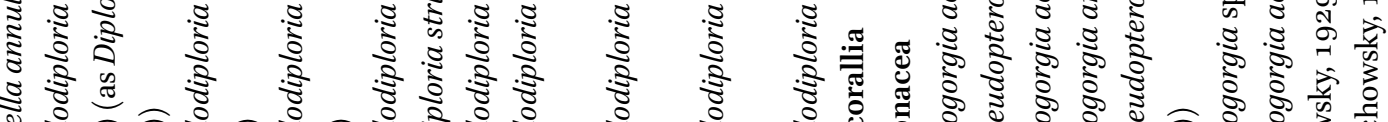

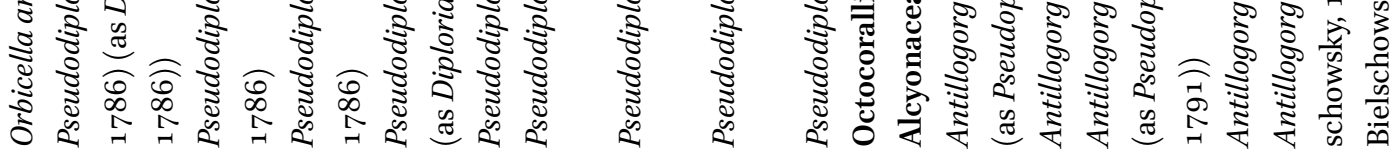




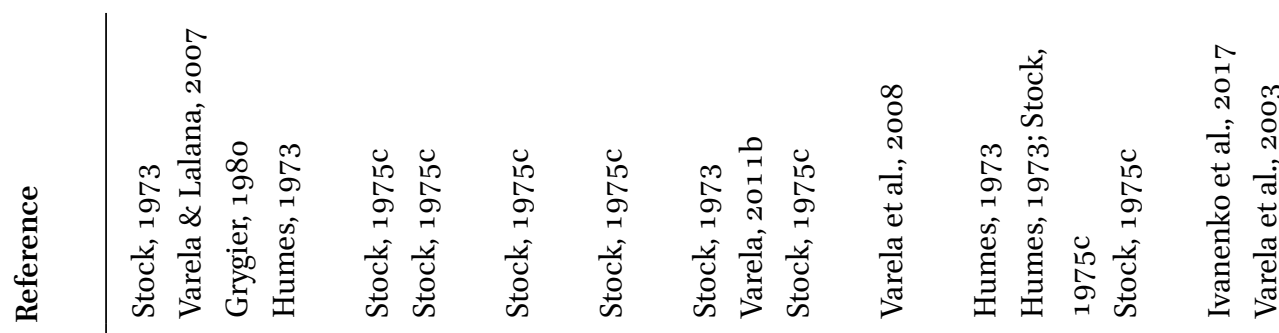

涪

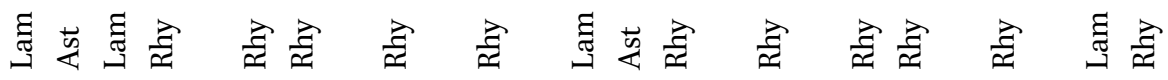

m in 10

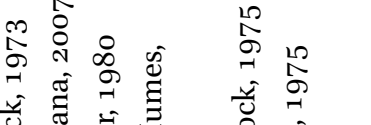

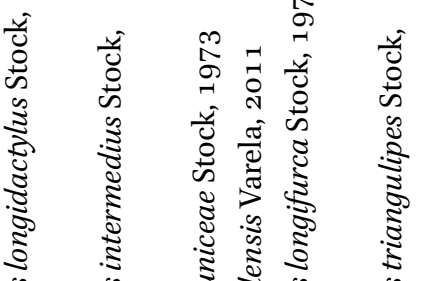

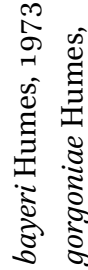

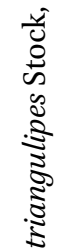

$\frac{\vec{u}}{\dot{0}}$

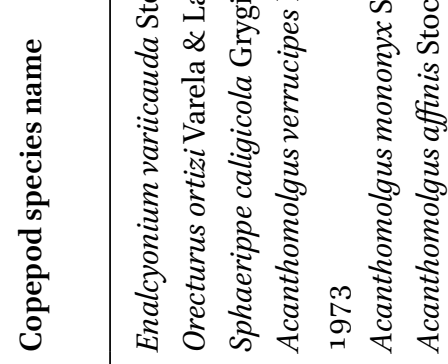

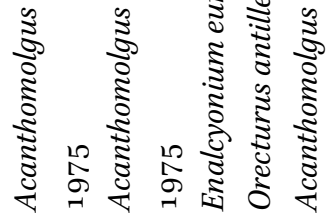

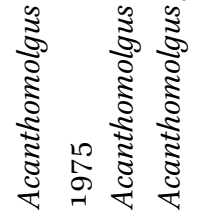

范 के

$\overparen{6}$

$\begin{array}{lll}0 & 0 & \infty \\ -\infty & \infty & 0\end{array}$

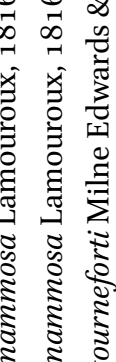

$\begin{array}{cccc}\infty & \infty & \infty & \infty \\ 10 & 10 & 10 & 10\end{array}$

ई

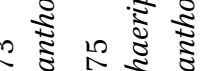




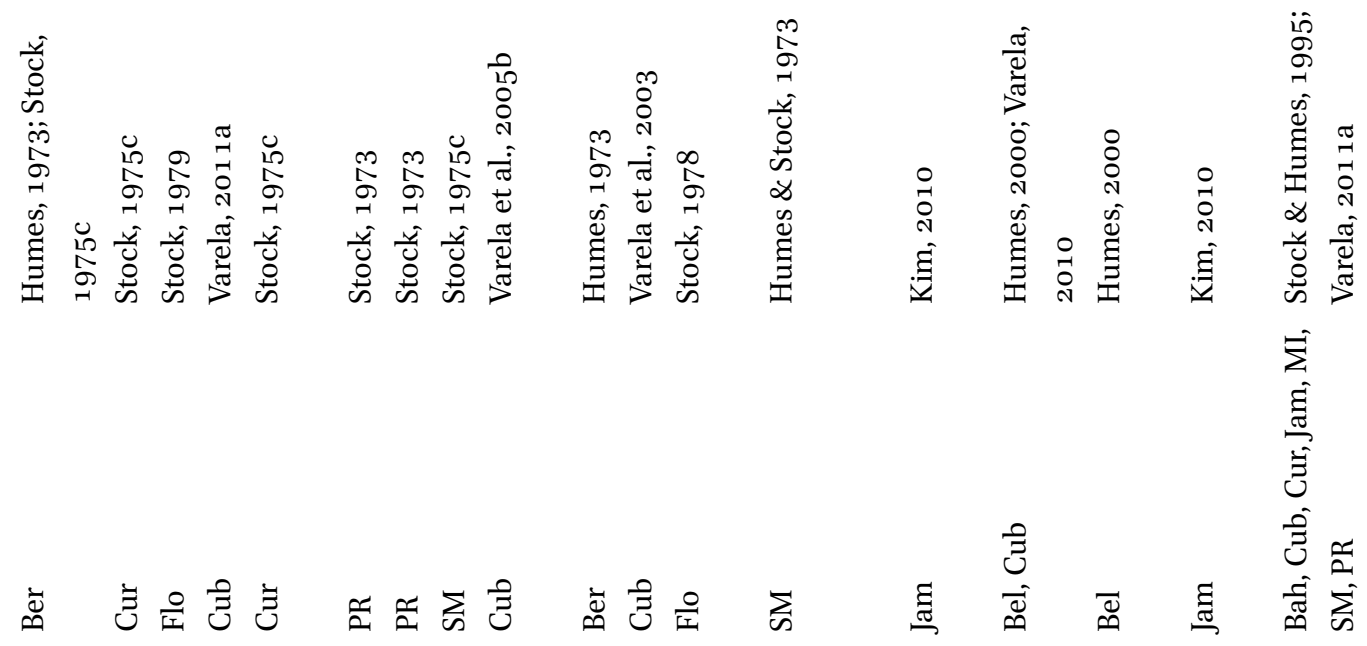

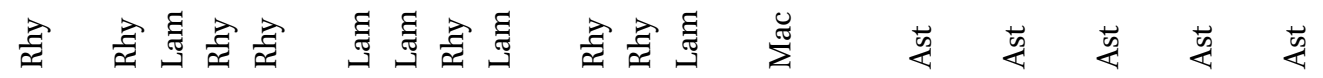
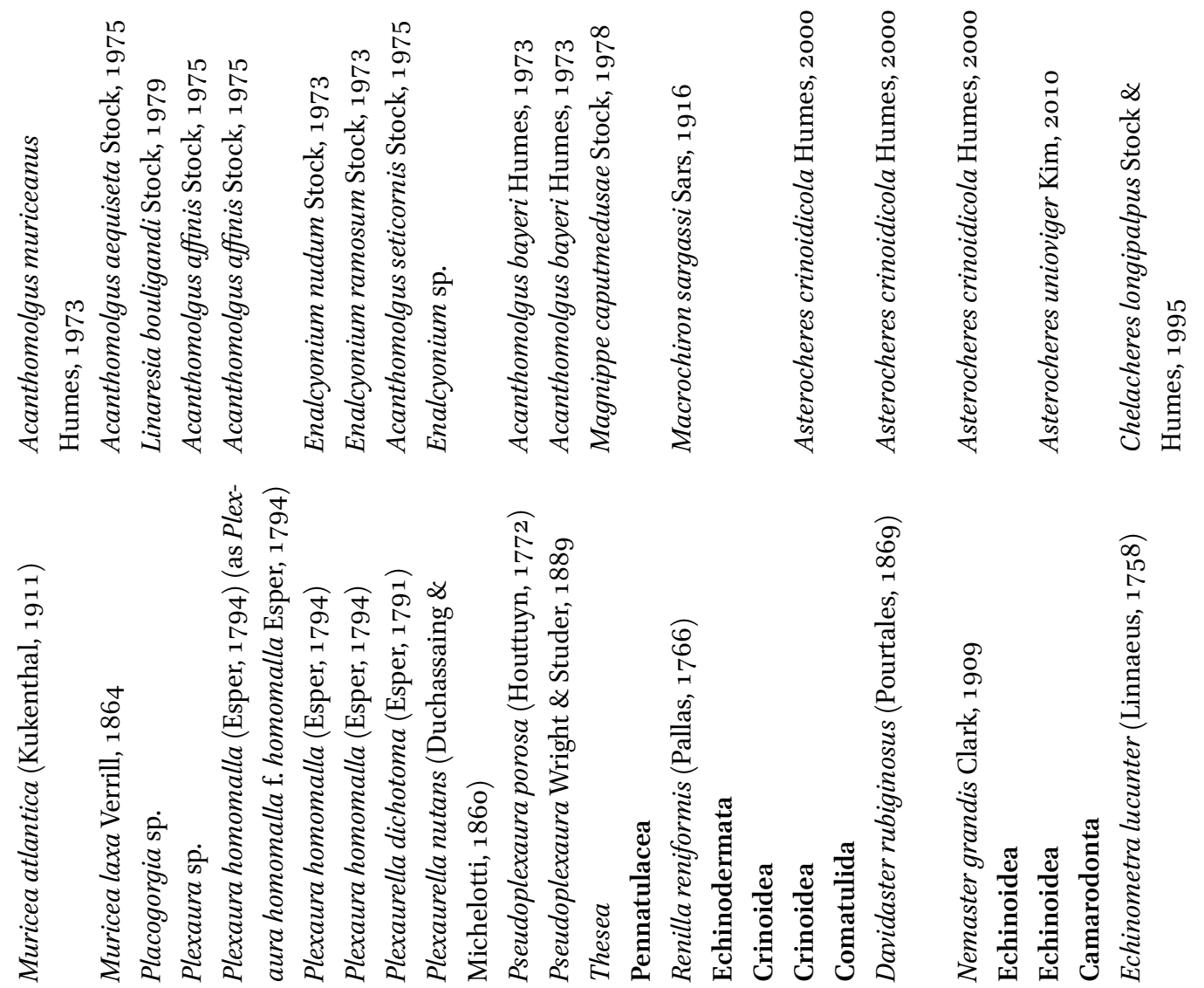


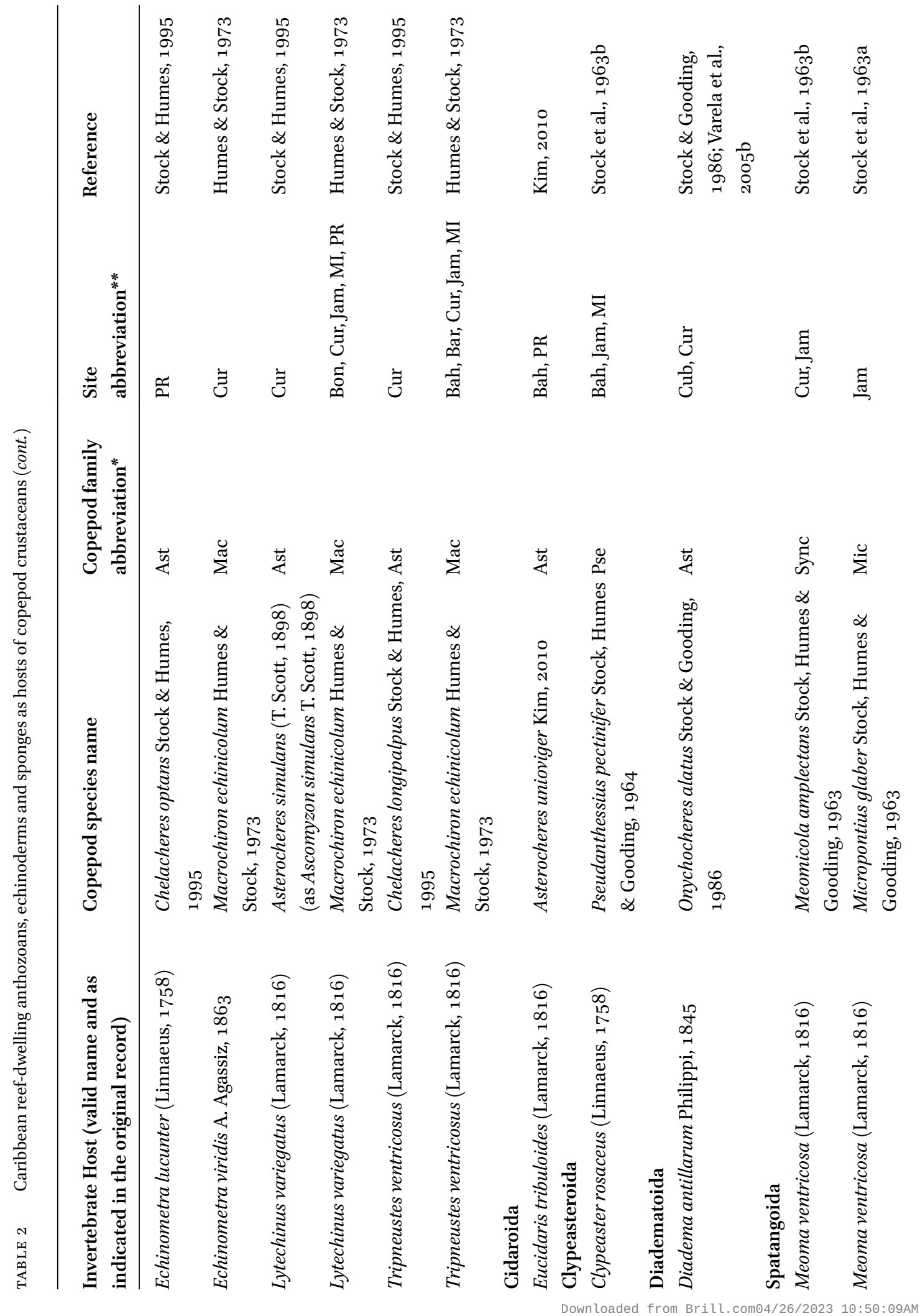




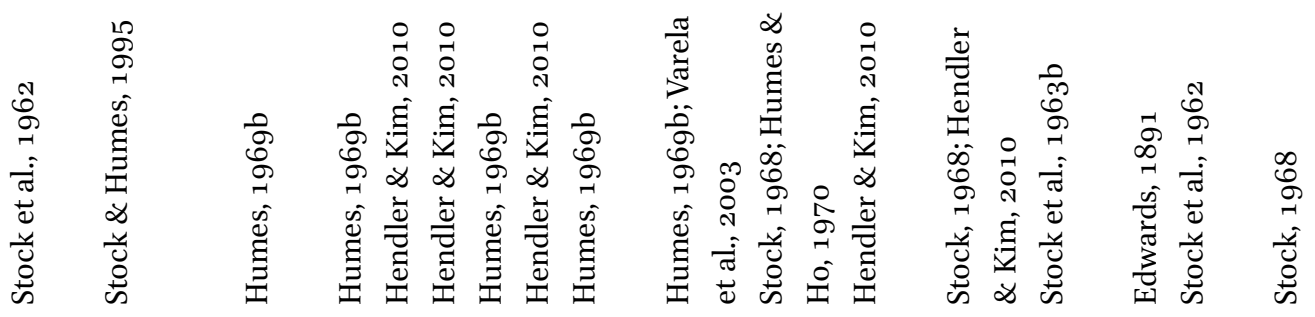

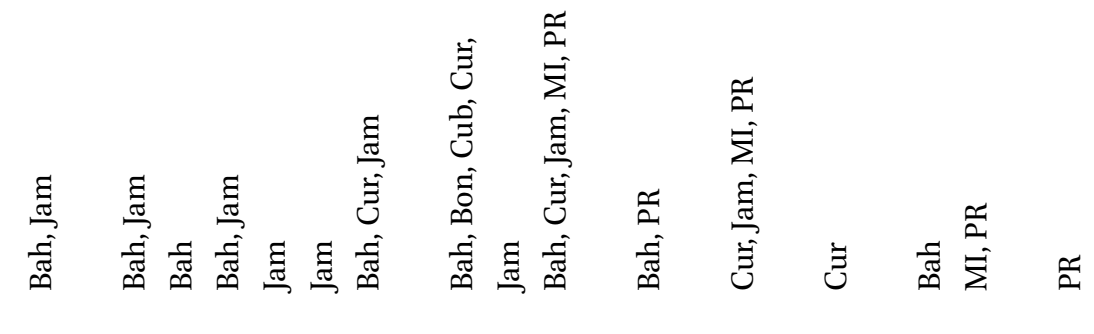

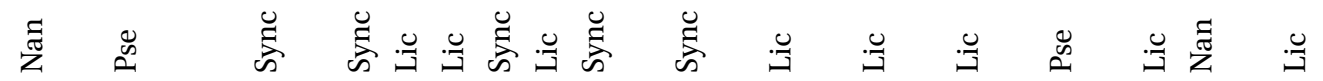

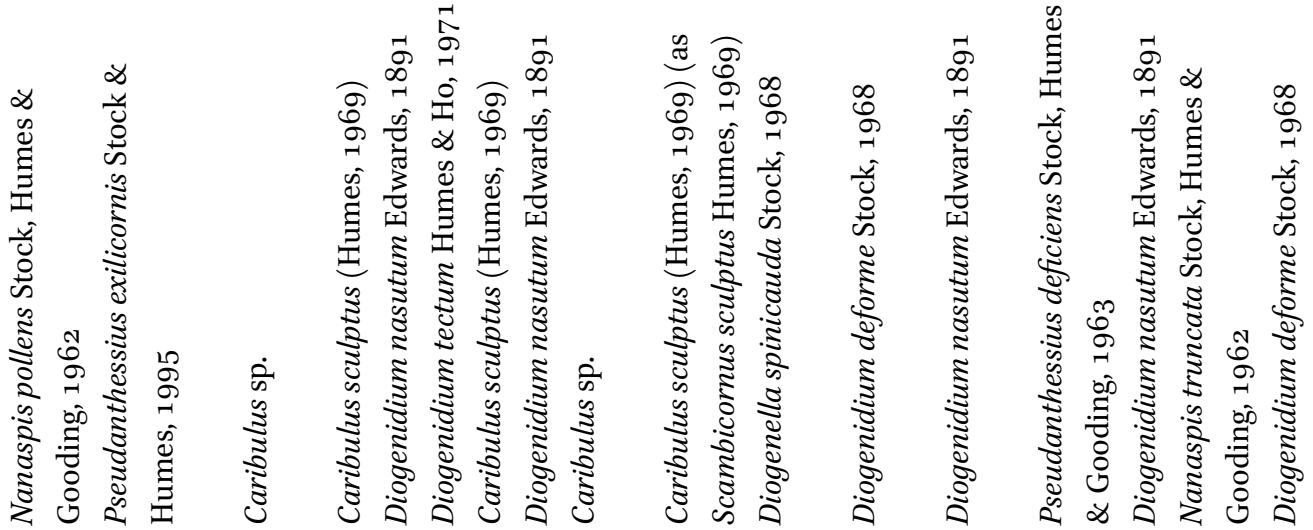

宫离

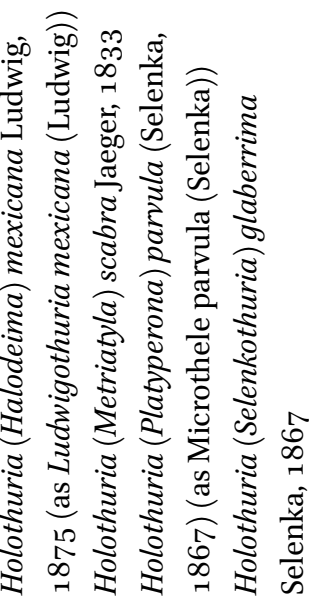




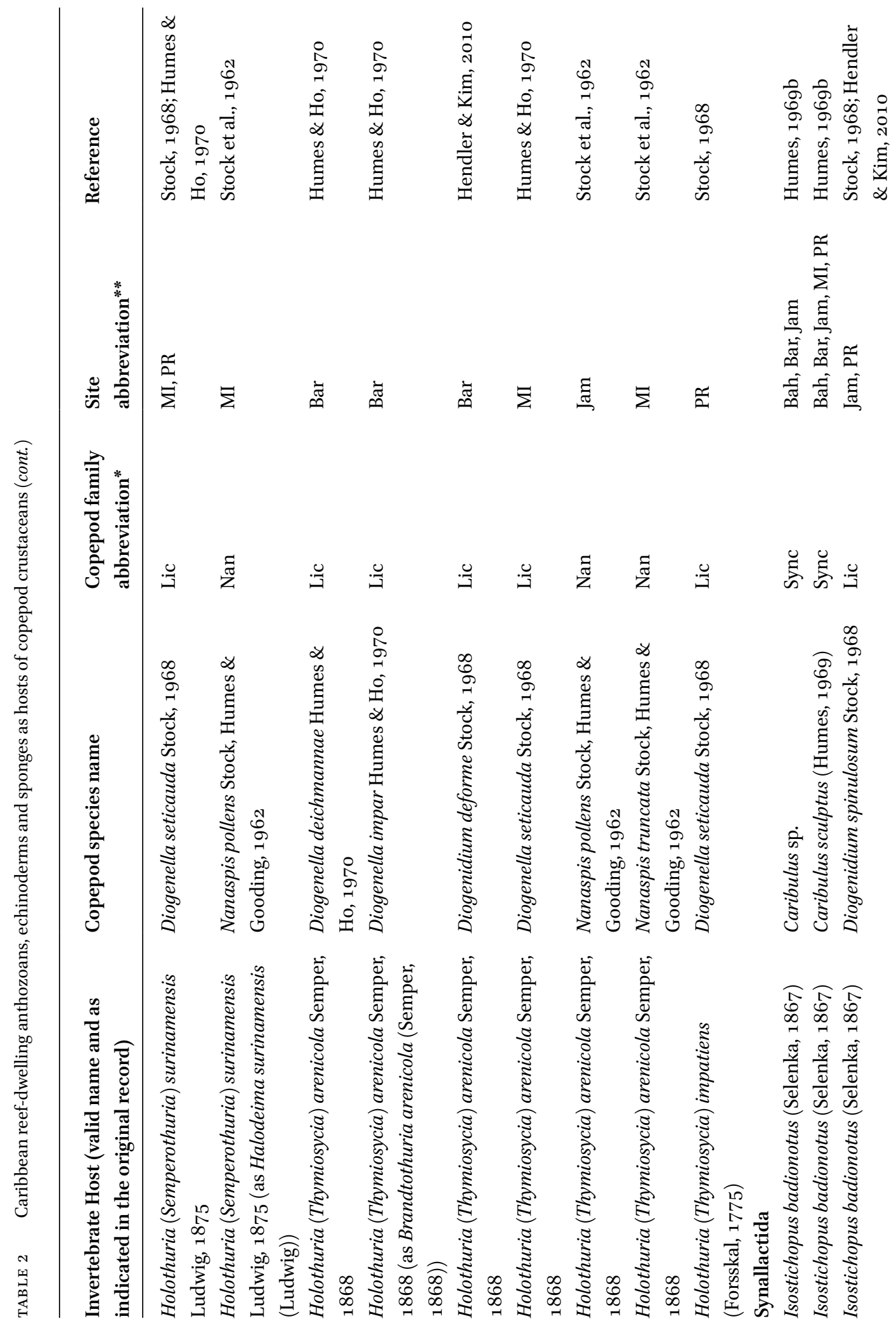




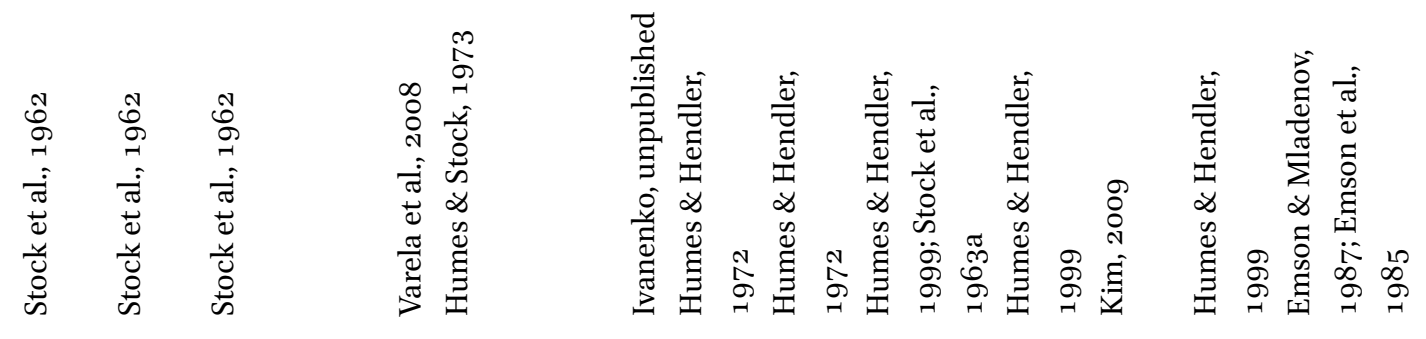

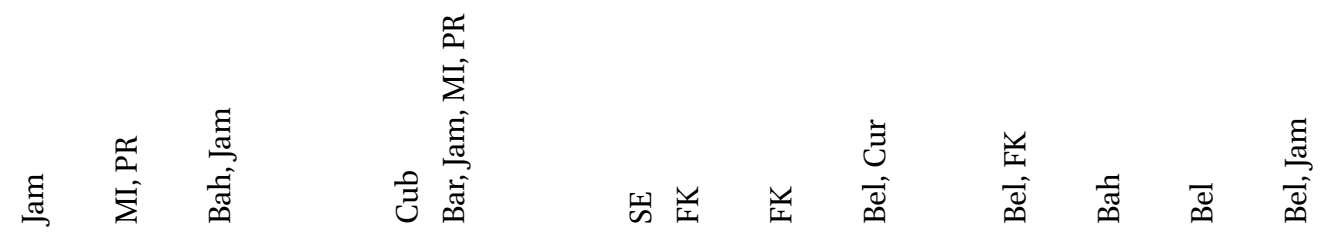

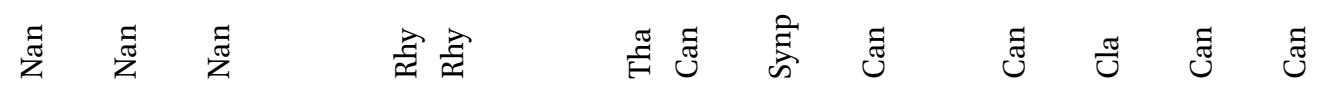
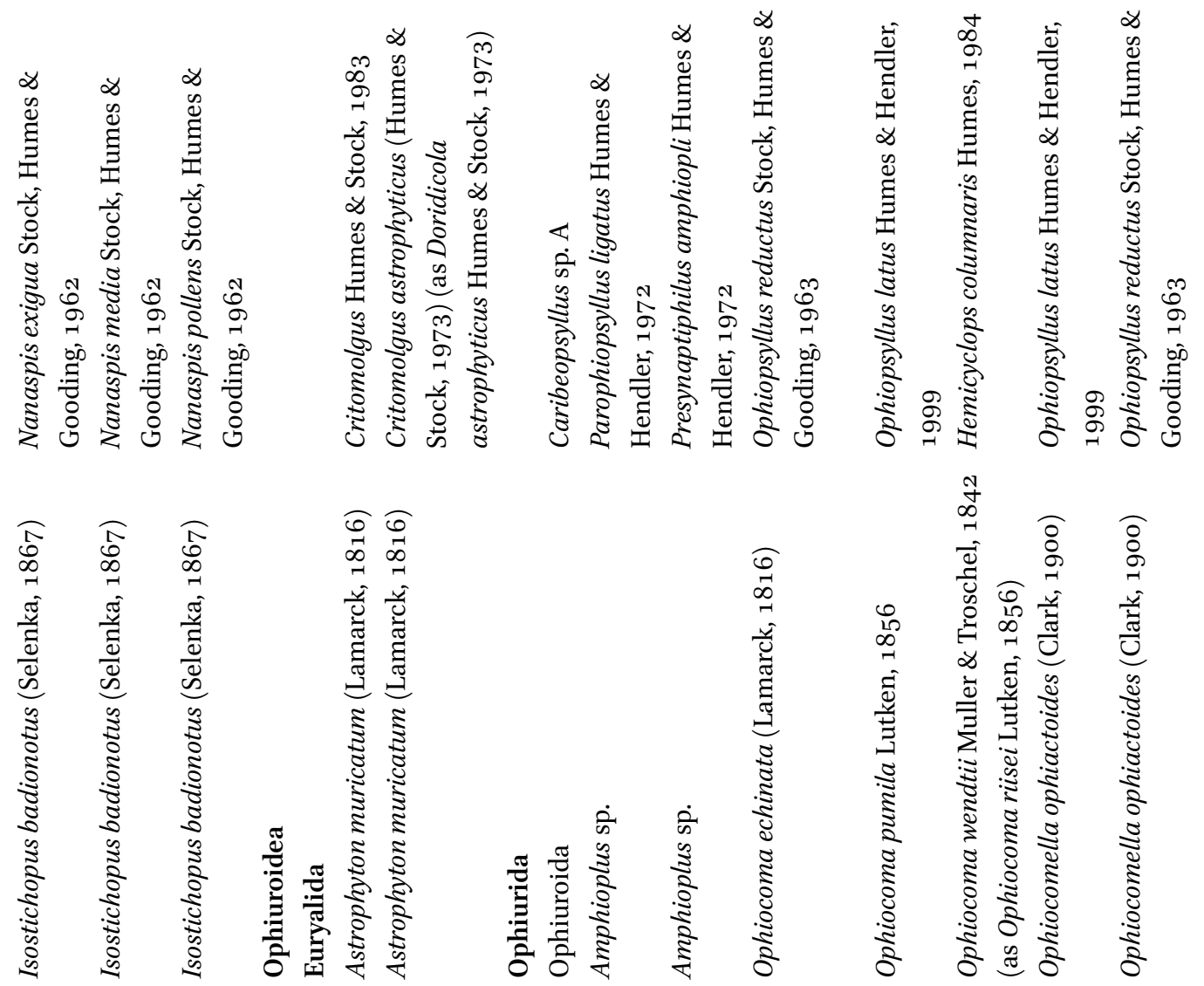


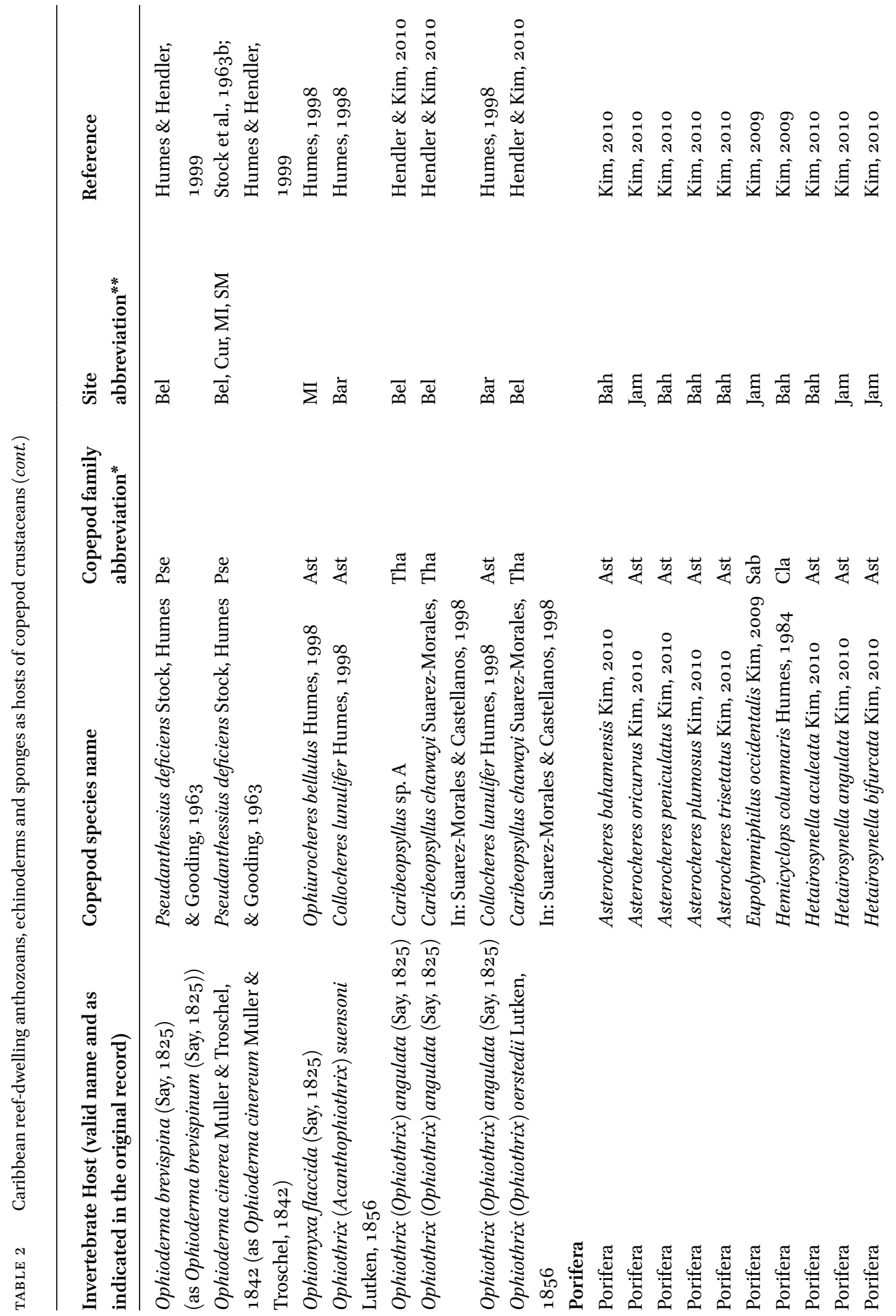




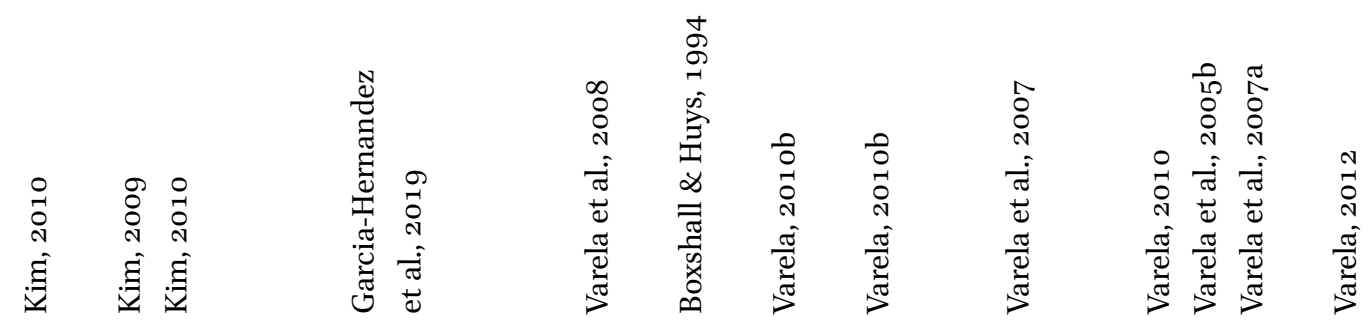

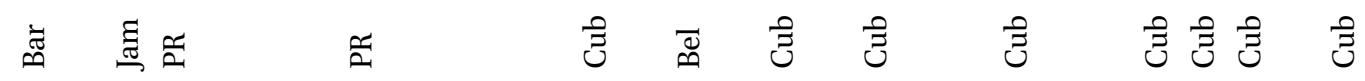

荌离莨

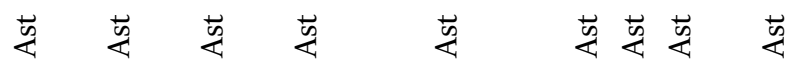

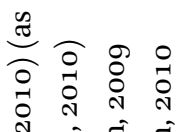

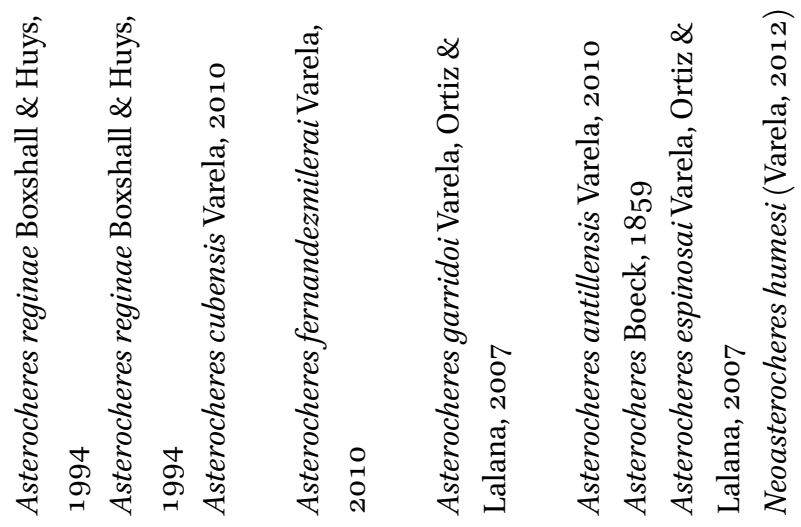

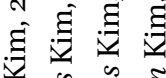

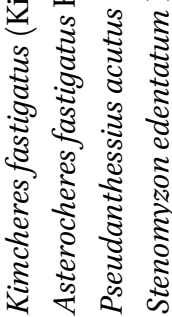

$\frac{\pi}{0}$
0
0
0
0

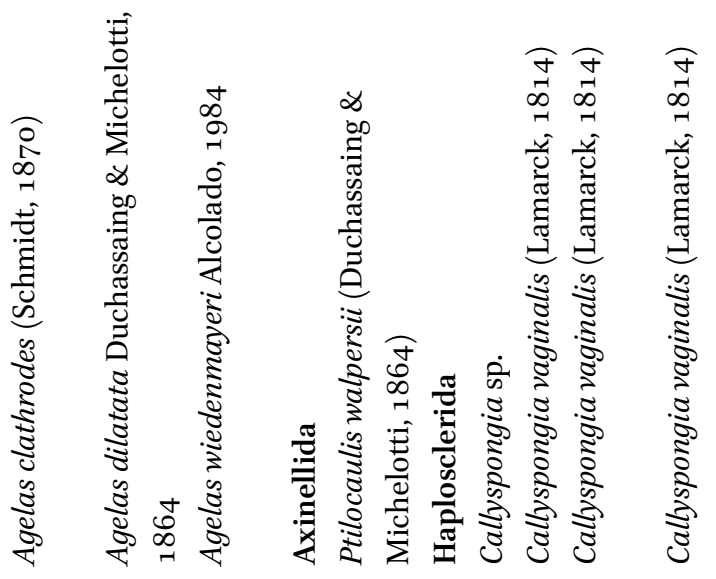




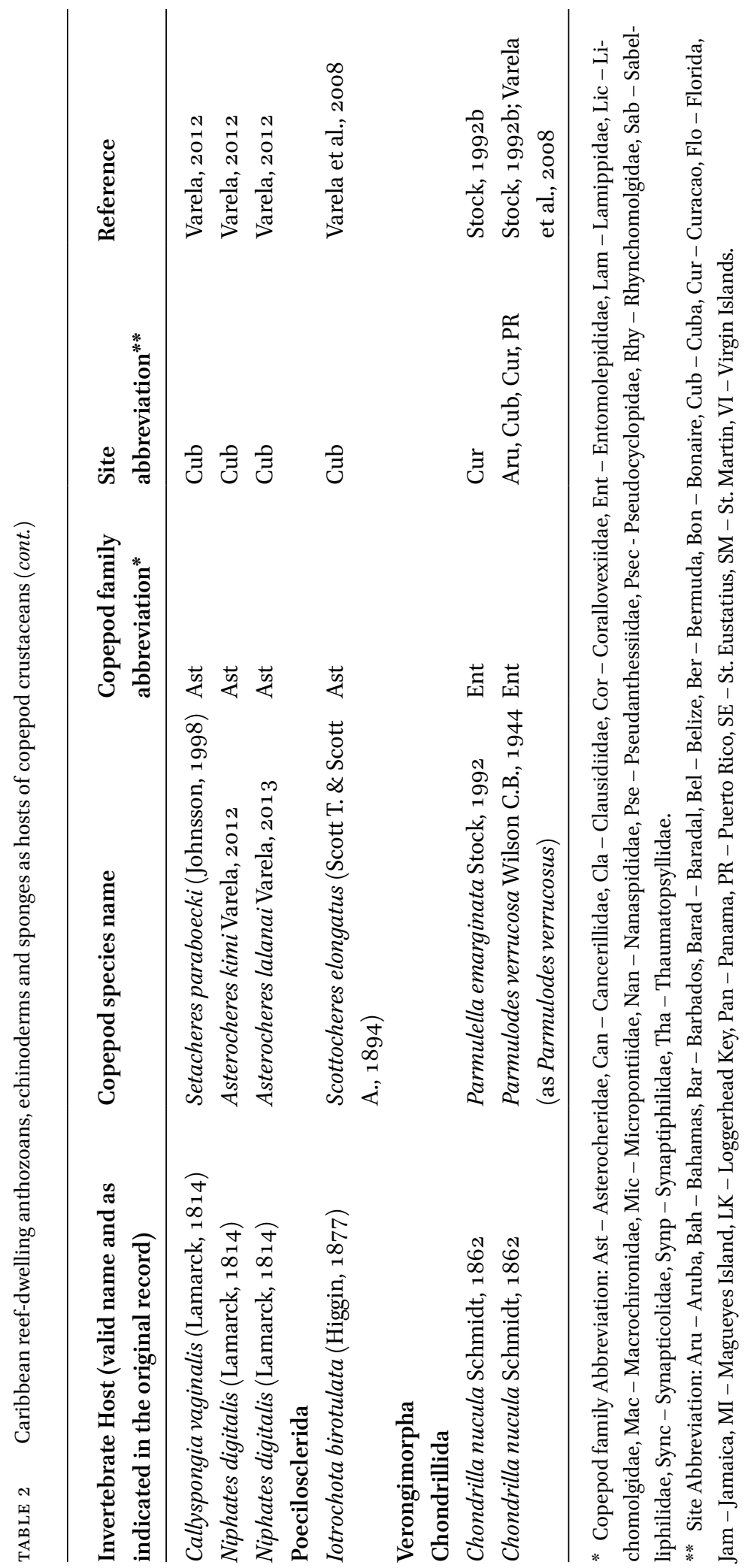


coral) (fig. 1a) (Humes, 1984; Stock, 1992a; Kim, 2009). All other species of symbiotic copepods are found in the Caribbean only, which may be the result of high endemism of their host species (Miloslavich et al., 2010; Soest et al., 2012; Zea et al., 2014; Ivanenko, 2016).

The copepods were collected by washing of the hosts in seawater or tap water (Butter, 1979; Garcia-Hernandez et al., 2017), a solution of formalin (Varela \& Lalana, 2007; Varela et al., 2003, 2005a, b, 2007a, b, 2008; Varela, 2010a, b, 2011a, b, 2012), a solution of ethanol (Stock et al., 1962, 1963a, b, Humes, 1969a, 1998, 2000; Humes \& Stock, 1973; Stock, 1975a, b, d; Herriott \& Immermann, 1979; Stock \& Humes, 1995) or a solution of magnesium-chloride (Stock \& Humes, 1995), dissecting of the host's tissues or galls (see Stock et al., 1962; Humes \& Hendler, 1972, 1999; Humes \& Goenaga, 1978; Stock, 1978; Grygier, 1980; Emson et al., 1985; Emson \& Mladenov, 1987; Hendler \& Kim, 2010; Ivanenko et al., 2017), by a suction device (Humes \& Stock, 1973) or by dissolving soft tissues of host corals with bleach (Stock 1975a, 1989). Most of the host invertebrates were collected by SCUBA living down to $41 \mathrm{~m}$ depth. The only exceptions are the three of eight species of the Caribbean copepods of the family Lamippidae tentatively included in the database found in galls or tissue of octocorals collected by a submersible away from reefs at depths of $55^{-330 ~ m ~(f i g . ~} 2$ a-d) (Stock, 1978, 1979; Grygier, 1980). It is noteworthy that there are no data on symbiotic copepods associated with reef-dwelling sponges, echinoderms and corals living at mesophotic depths; studies on reef communities and coral-associated fauna from mesophotic depths seems to be an important task that has just started (Bongaerts et al. 2010, 2015; van der Meij et al., 2015; Hoeksema et al., 2017c; García-Hernández et al., 2018; Veglia et al., 2018).

Symbiotic copepods are reported from eight out of ten ecoregions of the Greater Caribbean, but none from the Northern and
Southern Gulf of Mexico (table 6, figs. 4-7; Spalding et al., 2007; Hoeksema et al., 2017a). Eight records are known for Bermuda: four species of poecilostomatoid cyclopoids representing genus Acanthomolgus and the siphonostomatoid Ophiopsyllus reductus were found associated with alcyonaceans and an ophiuroid, respectively (Stock et al., 1963a; Humes, 1973). Only one record is reported for the Southwestern Caribbean: the calanoid Ridgewayia fosshageni aggregating on the actinairian Bartholomea annulata. Only Aspidomolgus stoichactinus living on the actiniarian Stichodactyla helianthus and the corallimorpharian Corynactis denticulosa, recorded as Homostichanthus denticulosus, is found in five ecoregions (Humes, 1969a; Stock, 1975b). Five species of copepods are found in four ecoregions, viz. Caribulus sculptus living on holothurians, Chelacheres longipalpus and Macrochiron echinicolum (fig. 1d) found on sea urchins, Ophiopsyllus reductus living on ophiuroids. Seventeen and 87 species of copepods are recorded found in only two and one ecoregions, respectively (table 6).

The data show that the three most intensively explored ecoregions are the Bahamian, Greater Antilles and Southern Caribbean, with studies centered at Curaçao (123 records, 36 species of hosts, 49 species of copepods), Puerto Rico $(105,22,27)$ and the Bahamas (57, $11,19)$. The mosaic data show poor knowledge of most ecoregions as well as and many host taxa. This current state of the knowledge limits analysis of the distribution of symbiotic copepods in the whole Caribbean. Well planned studies of different Caribbean regions and the application of modern methods of integrative taxonomy are needed to carry out such analyses (DeBiasse et al., 2016; Jossart et al., 2017; Ivanenko et al., 2018).

A comparison of taxonomic names from literature sources with their current nomenclature revealed name changes for 29 (of 80) species and 12 (of 58 ) genera of the hosts 

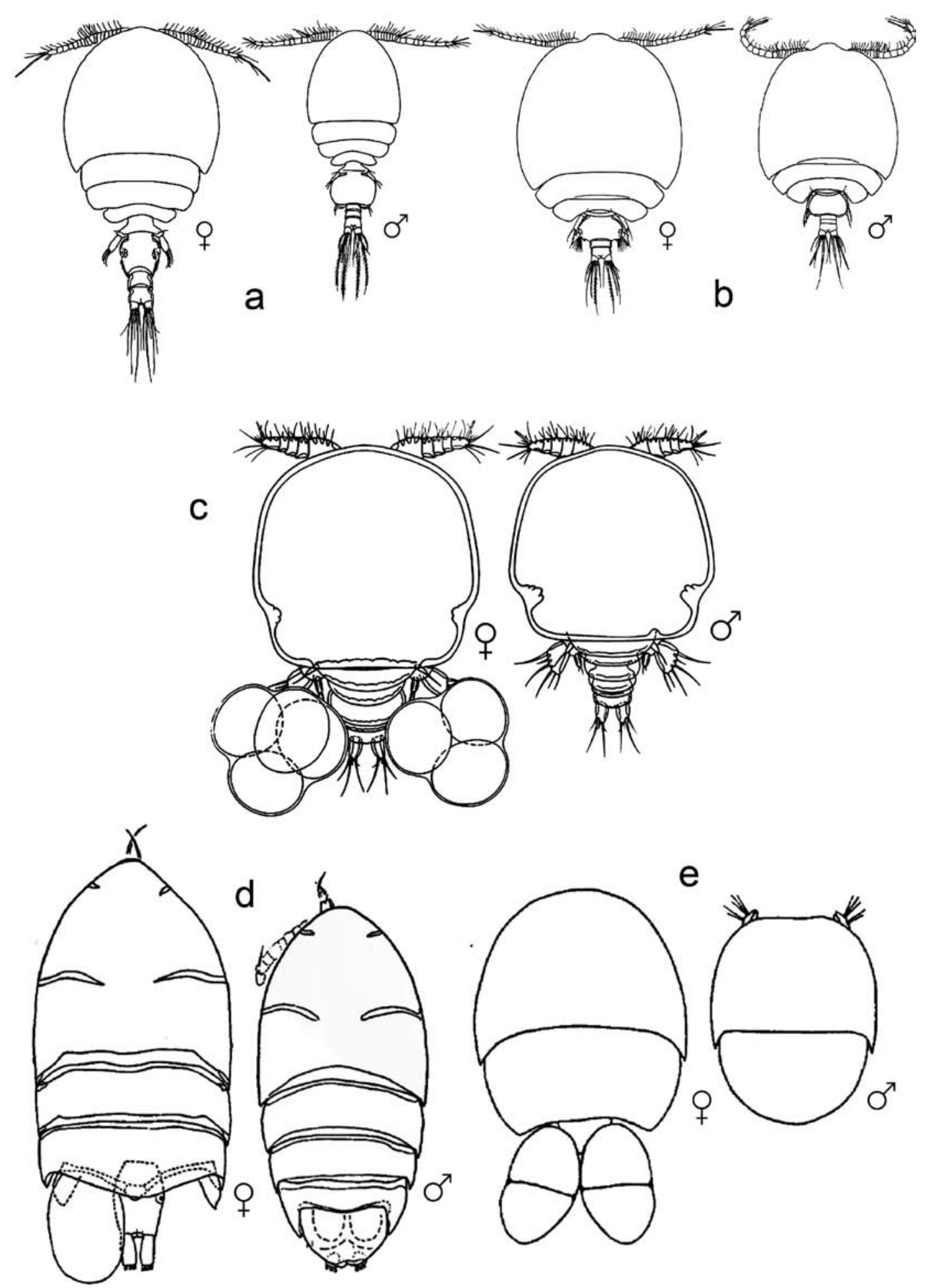

FIGURE 3 Siphonostomatoida, dorsal view. a - Asterocheres unioviger, b-Cyclocheres sensilis (Asterocheridae), c - Parophiopsyllus ligatus (Cancerillidae), d - Micropontius glaber (Micropontiidae), e - Nanaspis pollens (Nanaspididae). After Stock et al. (1962, 1963a), Humes \& Hendler (1972), Kim (2010). 
TABLE 3 Numbers of records and species of Caribbean symbiotic copepods found on reef-dwelling anthozoans, echinoderms and sponges attributed to the host family

\begin{tabular}{lll} 
Host family & $\begin{array}{l}\text { Number of copepod } \\
\text { records }\end{array}$ & $\begin{array}{l}\text { Number of copepod } \\
\text { species }\end{array}$ \\
\hline
\end{tabular}

\section{Echinodermata}

Holothuriidae

Stichopodidae

Ophiocomidae

Ophiotrichidae

Toxopneustidae

Echinometridae

17

Gorgonocephalidae

17

Ophiodermatidae

Amphiuridae

Brissidae

Clypeasteridae

9

Diadematidae

Comatulidae

Cidaridae

Ophiomyxidae

4

3

Cnidaria

Faviidae

Plexauridae

Stichodactylidae

Gorgoniidae

Meandrinidae

Actiniidae

Montastraeidae

Merulinidae

Acroporidae

Corallimorphidae

Briareidae

Aiptasiidae

Antipathidae

Ricordeidae

Renillidae

Phymanthidae

Primnoidae

Porifera

Clathrinidae

Chondrillidae 
TABLE 3 Numbers of records and species of Caribbean symbiotic copepods found on reef-dwelling anthozoans, echinoderms and sponges attributed to the host family (cont.)

\begin{tabular}{lcl} 
Host family & $\begin{array}{l}\text { Number of copepod } \\
\text { records }\end{array}$ & $\begin{array}{l}\text { Number of copepod } \\
\text { species }\end{array}$ \\
\hline Callyspongiidae & 5 & 4 \\
Agelasidae & 4 & 3 \\
Niphatidae & 2 & 2 \\
Iotrochotidae & 1 & 1 \\
Axinellidae & 1 & 1 \\
\hline
\end{tabular}

TABLE 4 Number of records and species per family of symbiotic copepods living on reef-dwelling Caribbean hosts (anthozoans, echinoderms and sponges)

\begin{tabular}{lcc}
\hline Copepod family & Number of records & Number of species \\
\hline Asterocheridae & 103 & 45 \\
Rhynchomolgidae & 78 & 19 \\
Corallovexiddae & 66 & 11 \\
Synapticolidae & 53 & 3 \\
Lichomolgidae & 43 & 8 \\
Cancerillidae & 34 & 3 \\
Pseudanthessiidae & 21 & 4 \\
Nanaspididae & 19 & 4 \\
Macrochironidae & 18 & 2 \\
Thaumatopsyllidae & 17 & 1 \\
Lamippidae & 16 & 8 \\
Entomolepididae & 12 & 2 \\
Synaptiphilidae & 3 & 1 \\
Clausidiidae & 2 & 1 \\
Micropontiidae & 2 & 1 \\
Pseudocyclopidae & 2 & 1 \\
Sabelliphilidae & 1 & 1 \\
\hline
\end{tabular}

(WoRMS, 2019). The taxonomic names are changed for nine (of 115) species and six (of 47) genera of the copepods. There are six records of symbiotic copepods identified to genus (Asterocheres, Corallovexia, Corallonoxia, Critomolgus, Enalcyonium, Sphaerippe). These taxa are included in; among 16 hosts (for 18 records) that have no identification at species level; of these one is assigned to a phylum, three to a class and 12 to a genus. There are
41 records for which the hosts are identified only to taxonomic categories such as phylum, order or subclass. There are 81 records of copepods found on sponges, but hosts of 14 of them are defined only to phylum (Kim, 2009, 2010). The absence of precise identifications and the necessity of linking outdated host names with valid ones show the need for specimen collections of not only copepods

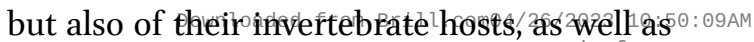


TABLE 5 Families of reef-dwelling Caribbean symbiotic copepods and their host families (anthozoans, echinoderms and sponges)*

\begin{tabular}{|c|c|c|}
\hline Copepod family & Host family & Host class or type \\
\hline \multirow[t]{21}{*}{ Asterocheridae } & Actiniidae & Ant \\
\hline & Agelasidae & Dem \\
\hline & Axinellidae & Dem \\
\hline & Briareidae & Ant \\
\hline & Callyspongiidae & Dem \\
\hline & Cidaridae & Ech \\
\hline & Comatulidae & Cri \\
\hline & Diadematidae & Ech \\
\hline & Echinometridae & Ech \\
\hline & Iotrochotidae & Dem \\
\hline & Meandrinidae & Ant \\
\hline & Merulinidae & Ant \\
\hline & Montastraeidae & Ant \\
\hline & Niphatidae & Dem \\
\hline & Ophiomyxidae & Oph \\
\hline & Ophiotrichidae & Oph \\
\hline & Phymanthidae & Ant \\
\hline & Plexauridae & Ant \\
\hline & Ricordeidae & Ant \\
\hline & Stichodactylidae & Ant \\
\hline & Toxopneustidae & Ech \\
\hline \multirow[t]{2}{*}{ Cancerillidae } & Amphiuridae & Oph \\
\hline & Ophiocomidae & Oph \\
\hline Clausidiidae & Ophiocomidae & Oph \\
\hline \multirow[t]{5}{*}{ Corallovexiidae } & Acroporidae & Ant \\
\hline & Meandrinidae & Ant \\
\hline & Merulinidae & Ant \\
\hline & Montastraeidae & Ant \\
\hline & Faviidae & Ant \\
\hline Entomolepididae & Chondrillidae & Dem \\
\hline \multirow[t]{4}{*}{ Lamippidae } & Briareidae & Ant \\
\hline & Gorgoniidae & Ant \\
\hline & Plexauridae & Ant \\
\hline & Primnoidae & Ant \\
\hline \multirow[t]{2}{*}{ Lichomolgidae } & Holothuriidae & Hol \\
\hline & Stichopodidae & Hol \\
\hline \multirow[t]{3}{*}{ Macrochironidae } & Echinometridae & Ech \\
\hline & Renillidae & Ant \\
\hline & Toxopneustidae & Ech \\
\hline Micropontiidae & Brissidae & Ech \\
\hline
\end{tabular}


TABLE 5 Families of reef-dwelling Caribbean symbiotic copepods and their host families (anthozoans, echinoderms and sponges)* (cont.)

\begin{tabular}{lll}
\hline Copepod family & Host family & Host class or type \\
\hline Nanaspididae & Brissidae & Ech \\
& Holothuriidae & Hol \\
Pseudanthessiidae & Stichopodidae & Hol \\
& Brissidae & Ech \\
& Clypeasteridae & Ech \\
Rhynchomolgidae & Holothuriidae & Hol \\
& Ophiodermatidae & Oph \\
& Actiniidae & Ant \\
& Antipathidae & Ant \\
& Corallimorphidae & Ant \\
& Gorgoniidae & Ant \\
Synaptiphilidae & Gorgonocephalidae & Oph \\
Thaumatopsyllidae & Plexauridae & Ant \\
\hline & Ricordeidae & Ant \\
Synapticolidae & Stichodactylidae & Ant \\
& Porifera & Po \\
& Brissidae & Ech \\
& Holothuriidae & Hol \\
& Ophiotrichidae & Oph \\
& Stichopodidae & Hol \\
& Amphiuridae & Oph \\
& Ophiotrichidae & Oph \\
\hline
\end{tabular}

* Abbreviations: Ant - Anthozoa, Cri - Crinoidea, Dem - Demospongiae Ech - Echinoidea, Hol - Holothuroidea, Hom - Homoscleromorpha, Oph - Ophiuroidea, Po - Porifera.

morphological and molecular studies of this material (Rocha et al., 2014). The DNA-barcoding of the hosts, photographing of hosts alive underwater, and photographing of host skeletons along with basic locality data are important for both identification and maintaining information about each copepod host and the establishment of base line information about their distributions (Hoeksema et al., 2011).

In total, there are 253, 197 and 81 records of copepods found associated with echinoderms, cnidarians and sponges, respectively (figs. 1-3). Forty-seven and 20 records of copepods are linked to the scleractinian coral families Favii- dae and Meandrinidae (updated classification in Hoeksema \& Cairns, 2019), respectively; 36 and 16 of these records pertain to the endoparasitic copepod symbionts belonging to the family Corallovexiidae. Most records from holothurians from the families Holothuriidae and Stichopodidae ( 75 and 35 records), from ophiuroids the families Ophiocomidae and Ophiotrichidae (29 and 19 records) are most common, from sea cucumbers the family Stichopodidae (35 records) is well represented, alcyonaceans the family Plexauridae (29), and corallimorpharians (four records) also are represented (table 3). Many 


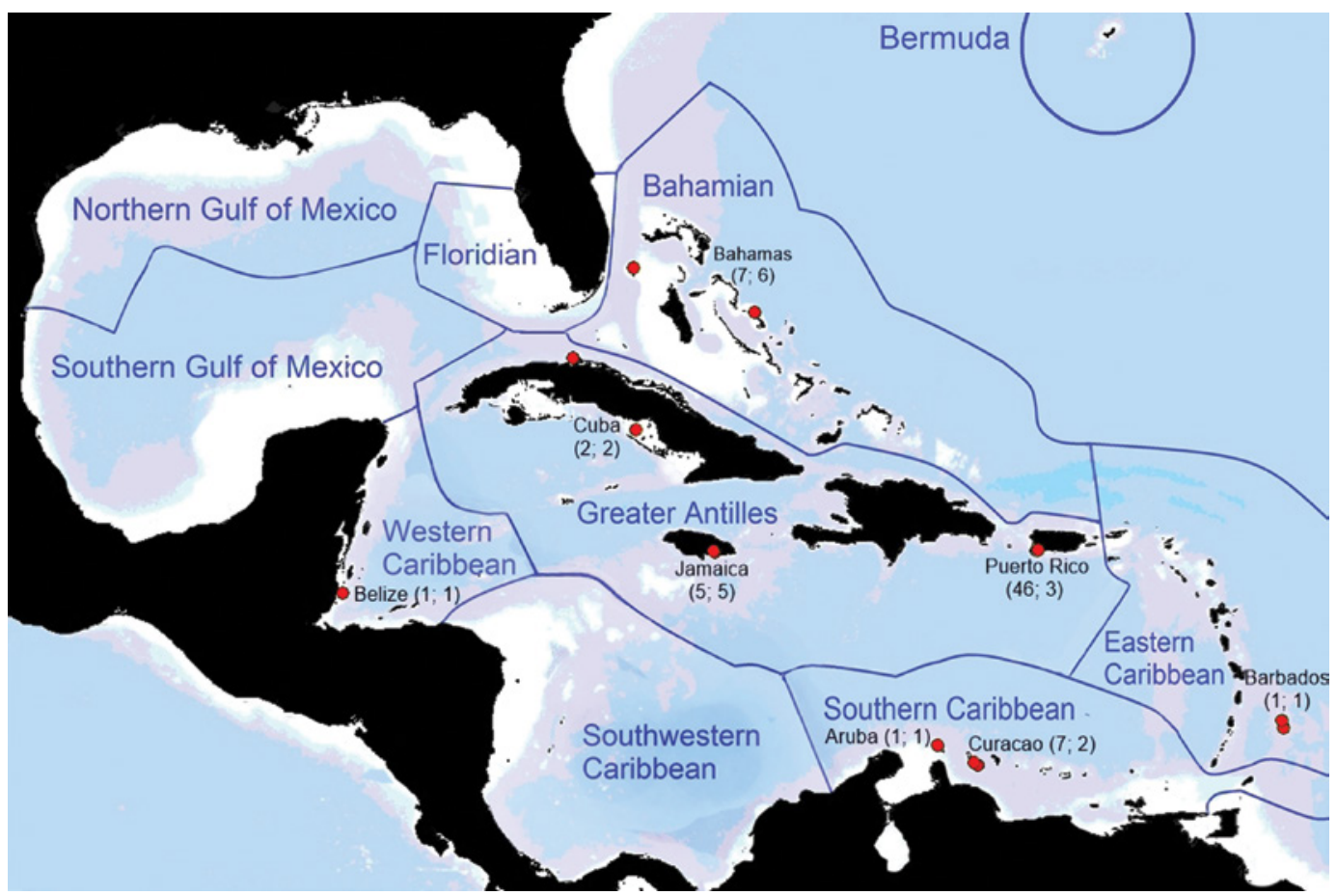

FIGURE 4 Caribbean copepods found on sponges $(\mathrm{x} ; \mathrm{x}=$ number of records and number of copepod species, respectively).

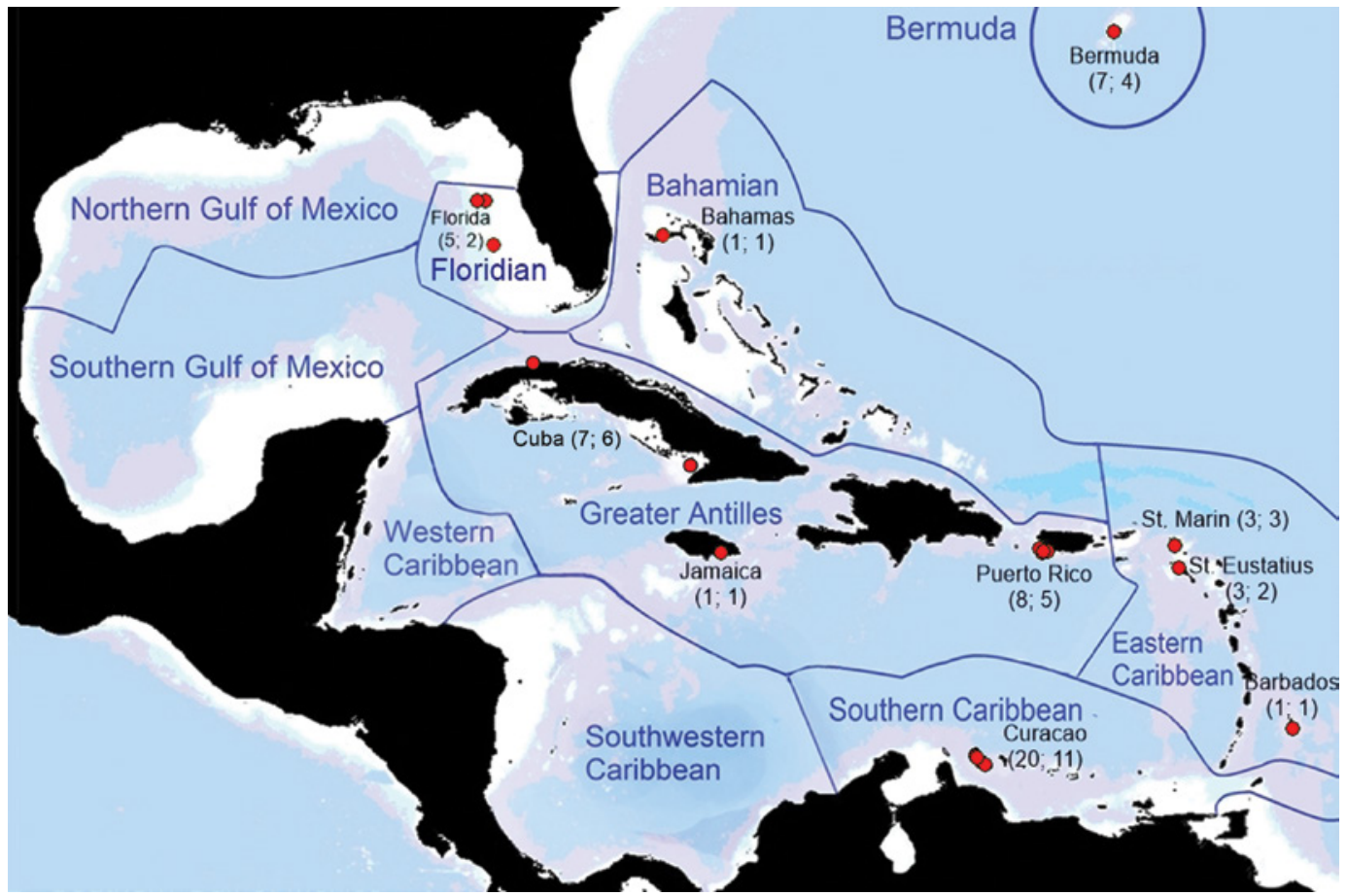

FIGURE 5 Caribbean copepods found on octocorals (Anthozoa: Octocorallia) (x; $\mathrm{x}$ - number of records and number of copepod species, respectively). 


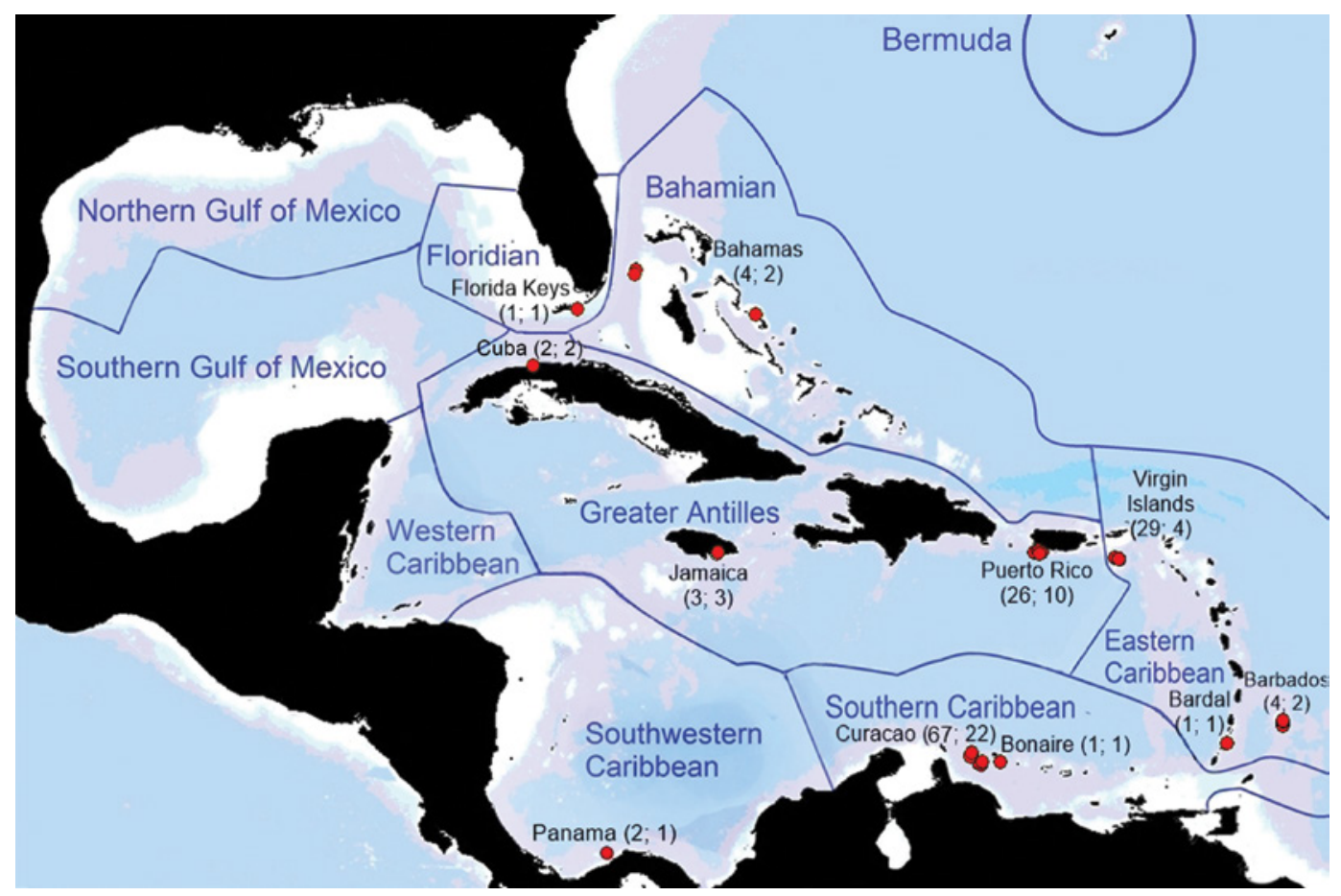

FIGURE 6 Caribbean copepods found on hexacorallians (Anthozoa: Hexacorallia) ( $x ; x$ - number of records and number of copepod species, respectively).

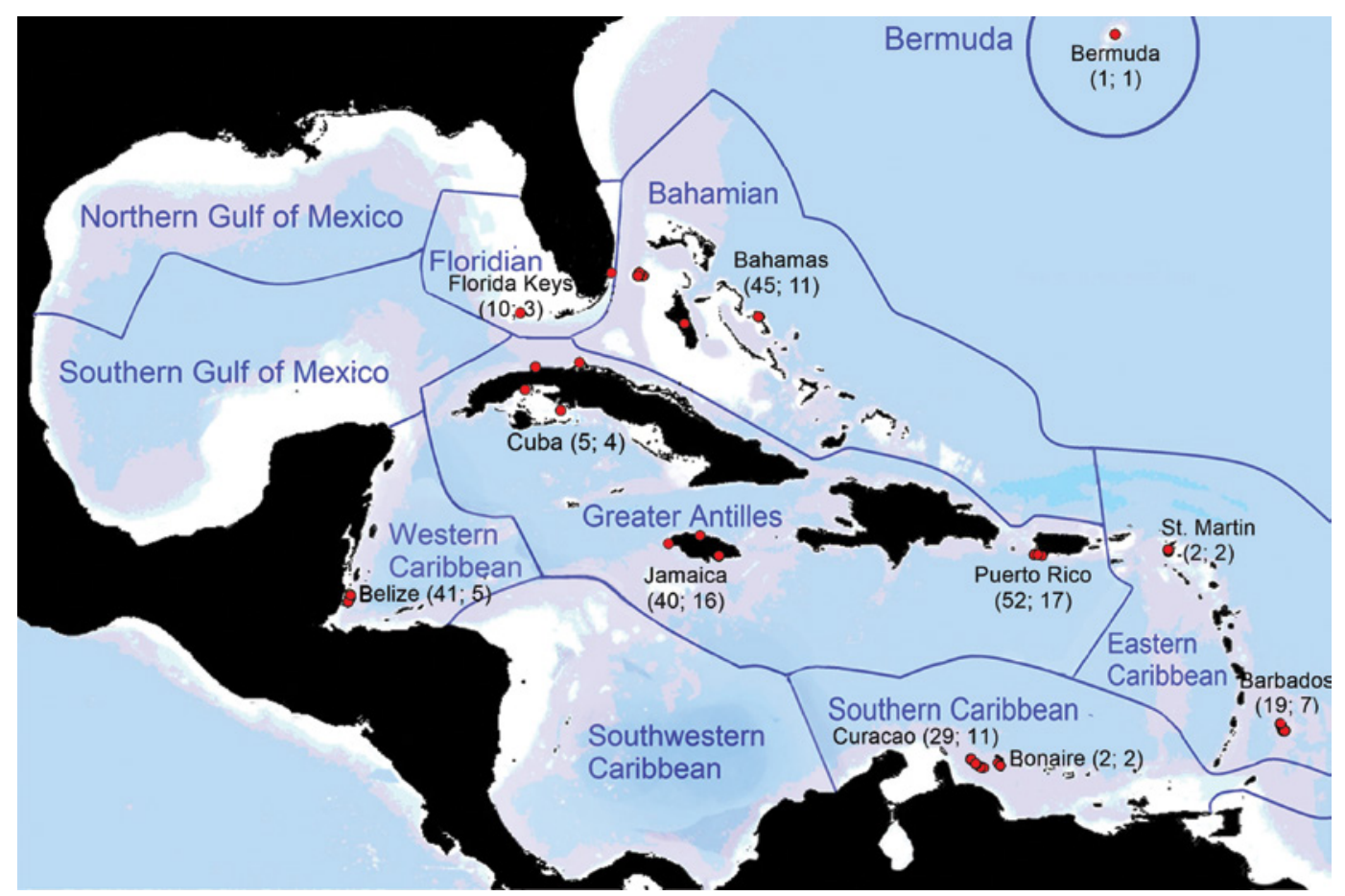

FIGURE 7 Caribbean copepods found on echinoderms ( $x ; x$ - number of records and number of copepod species, respectively). 


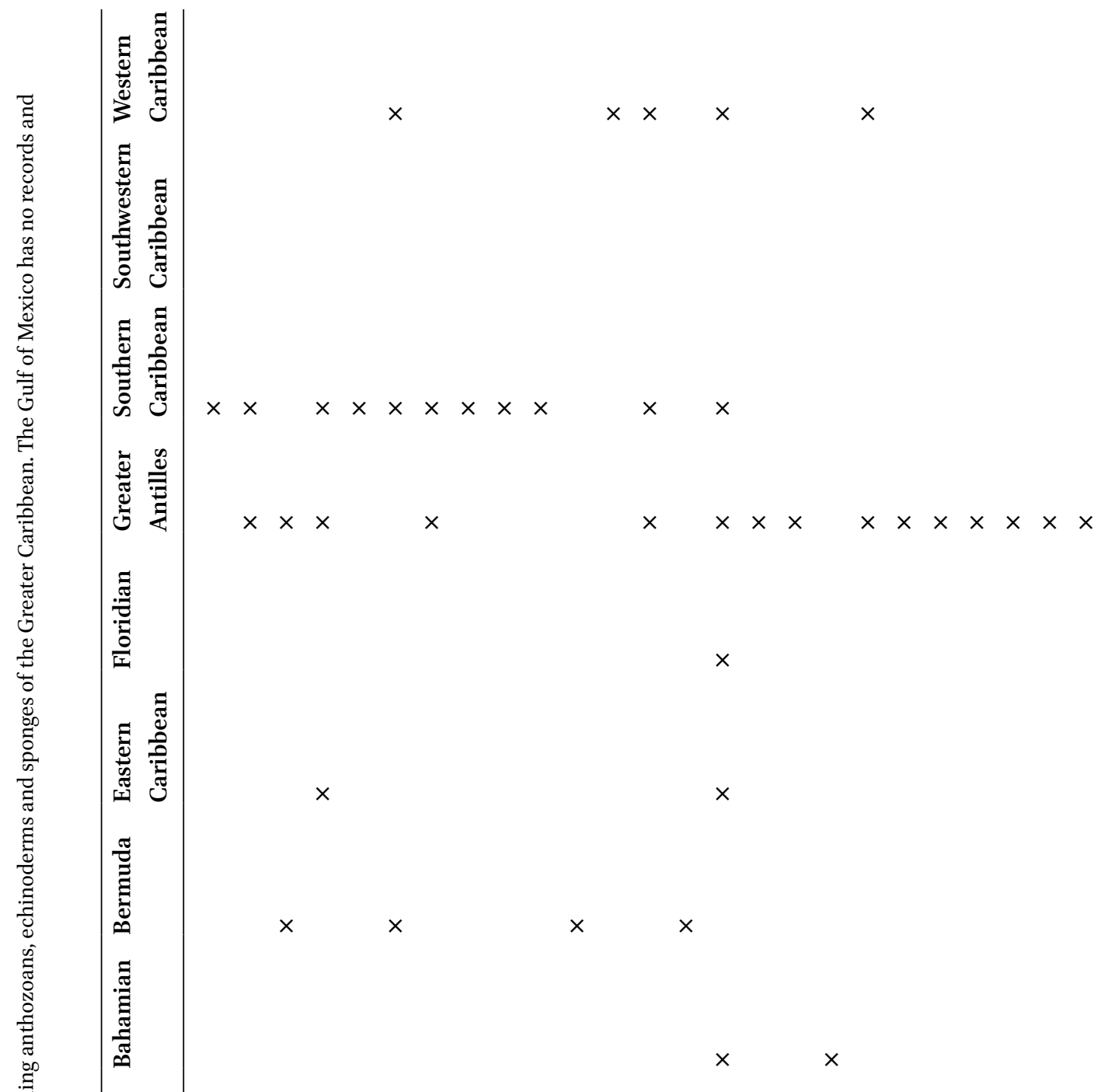

今̂े

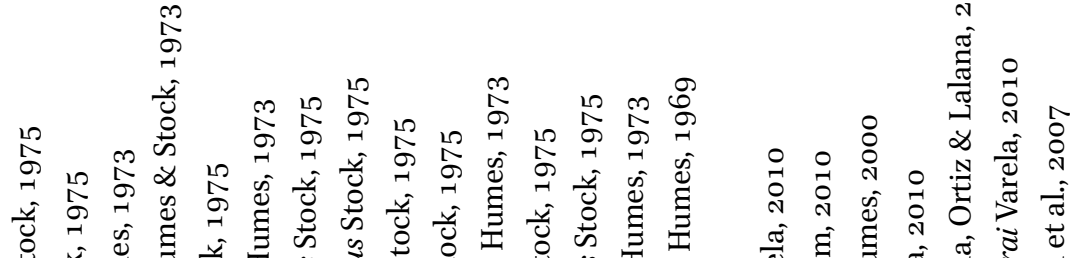

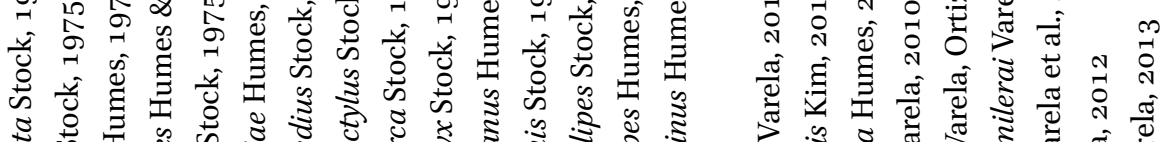

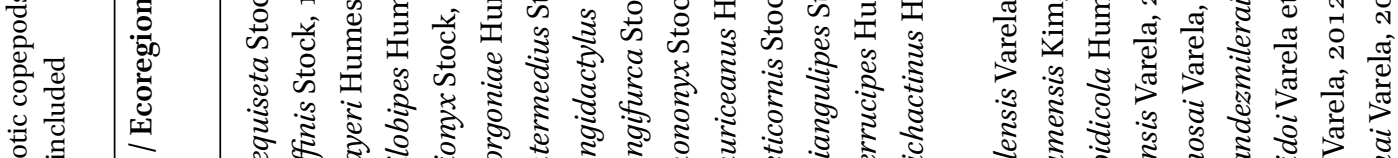
: व

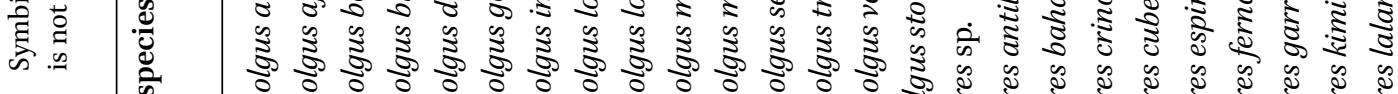

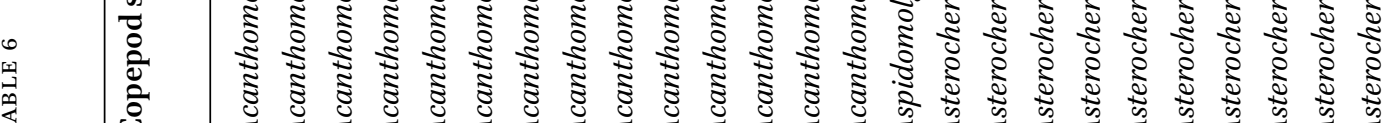

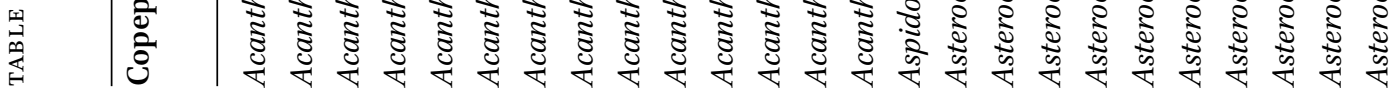




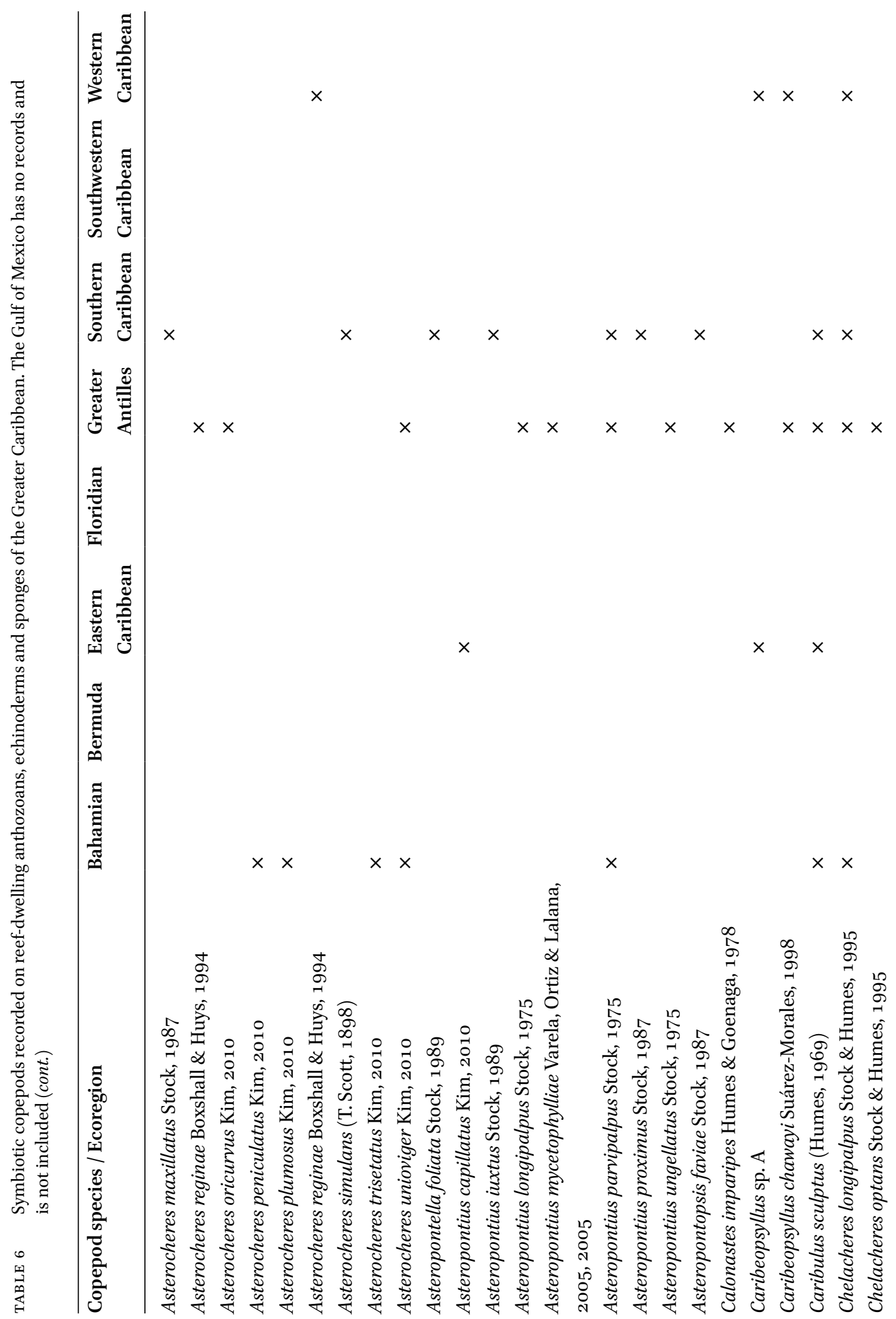



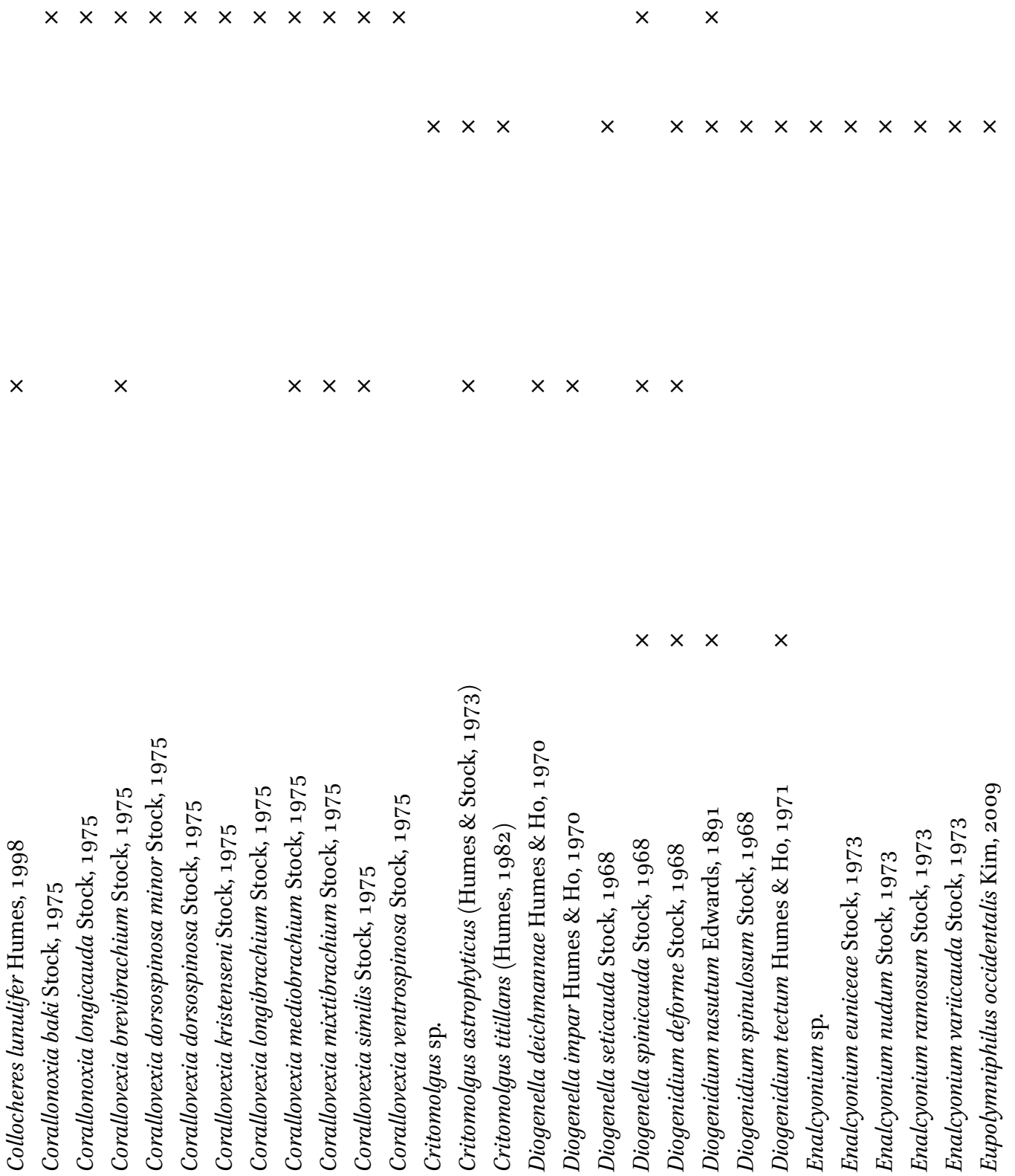


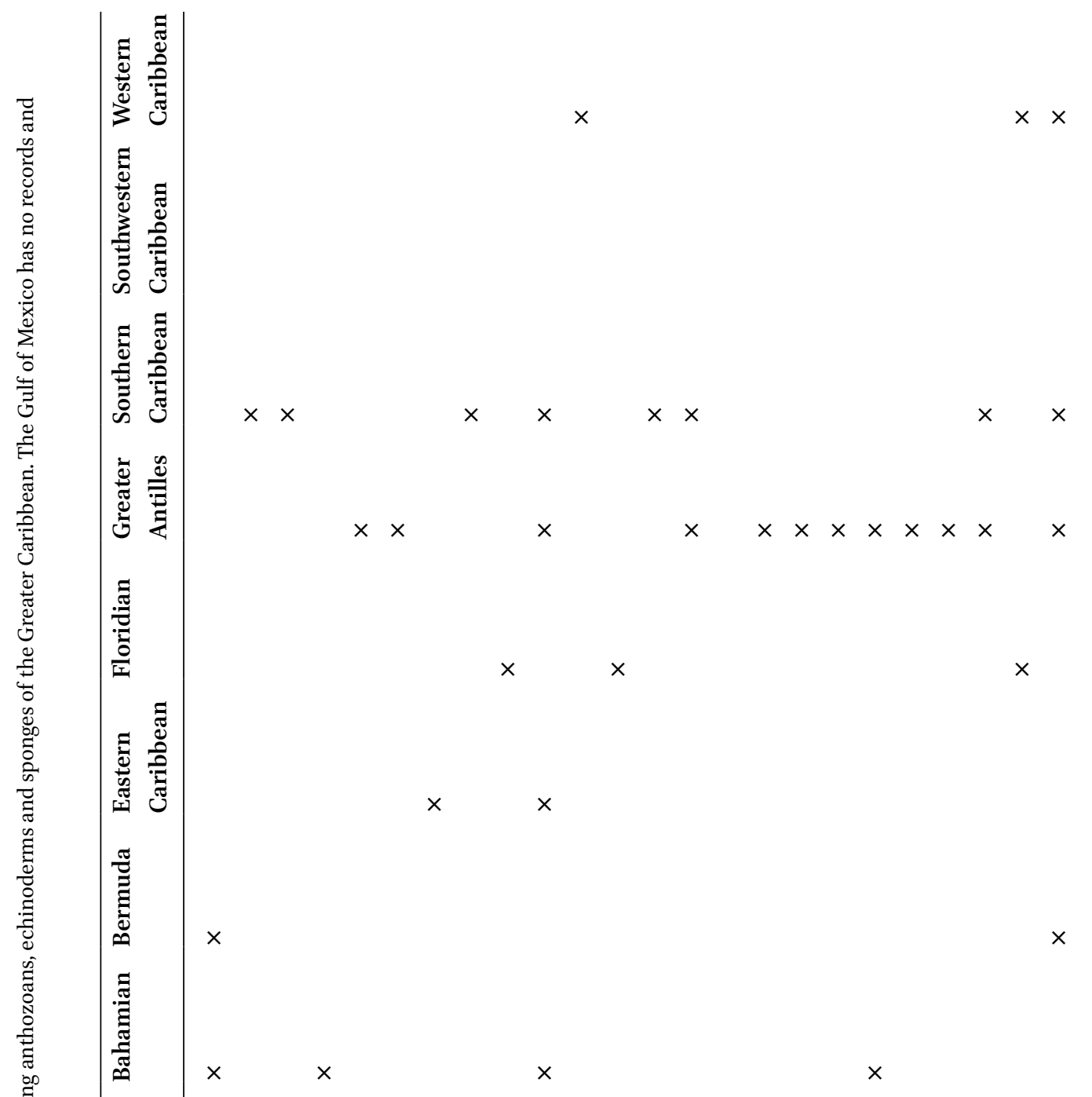

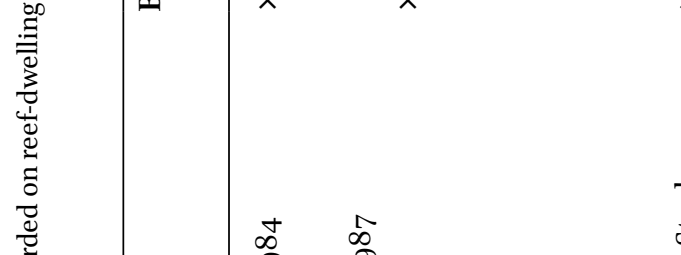



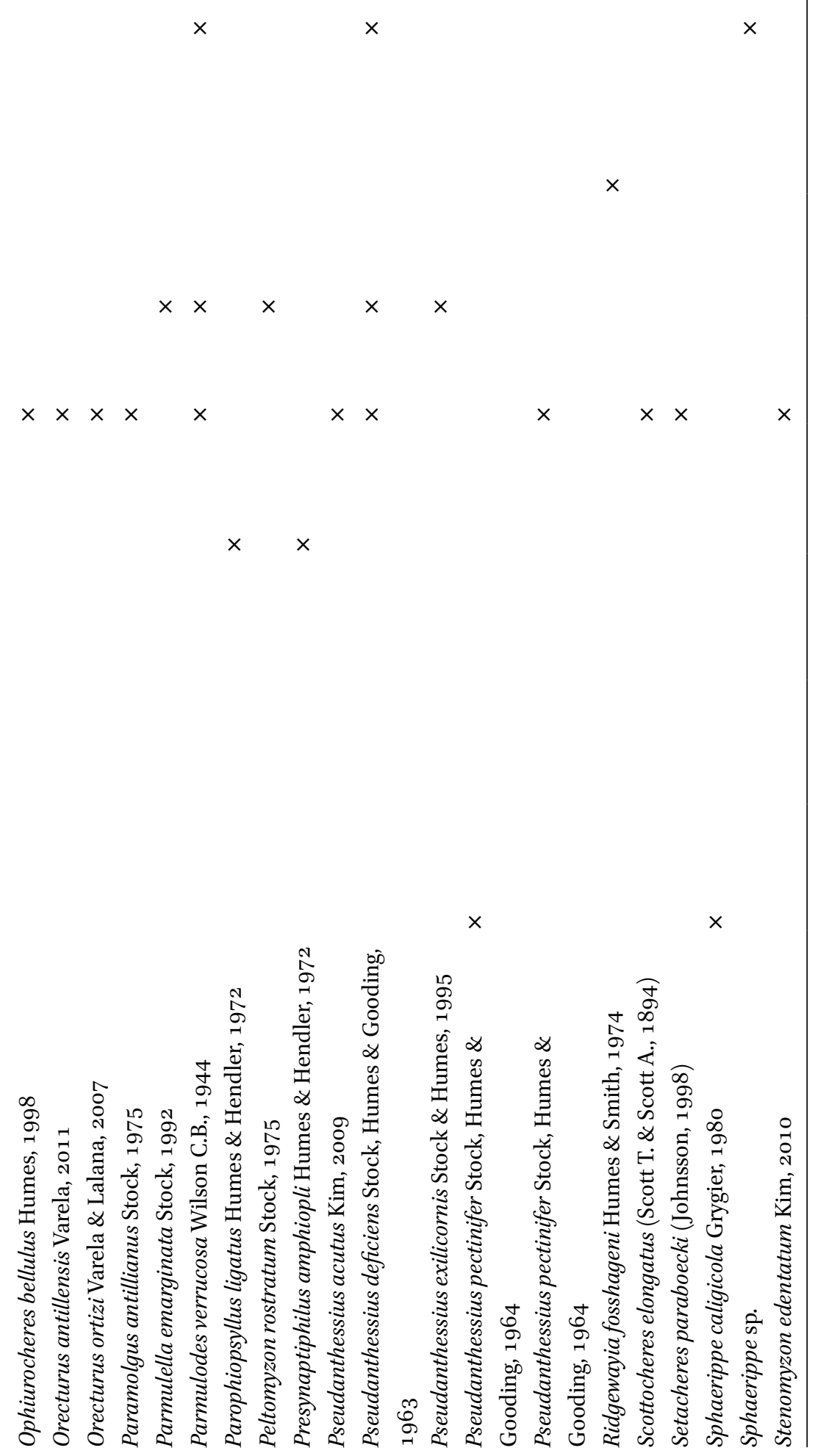
TABLE 7 Numbers of reef-dwelling species of Caribbean anthozoans, sponges, and echinoderms recorded as host for copepods

\begin{tabular}{lccc}
\hline Taxa & $\begin{array}{l}\text { Estimated number of } \\
\text { invertebrate host species }\end{array}$ & $\begin{array}{l}\text { Number of species } \\
\text { associated with } \\
\text { copepods }\end{array}$ & $\begin{array}{l}\text { Percent of } \\
\text { total species }\end{array}$ \\
\hline Subclass Hexacorallia (1) & 45 & 21 & $47 \%$ \\
Subclass Octocorallia (2) & 195 & 18 & $9 \%$ \\
Phylum Echinodermata (3, 4) & 955 & 31 & $3 \%$ \\
Phylum Porifera (5) & 760 & 9 & $1 \%$ \\
Total number & 1955 & 79 & $4 \%$ \\
\hline
\end{tabular}

1 - Ivanenko, 2016, 2 - Bayer, 1961, 3 - Alvarado, 2011, 4 - Pawson et al., 2009, 5 - Perez et al., 2017

(25 of 81 ) records of copepods found on unidentified sponges.

Cyclopoida, representing mainly poecilostomatoids, with 317 records for 59 species is the most diverse order of copepods found in symbiosis with corals, sponges and echinoderms; Siphonostomatoida with 170 records of 55 species is the next (figs. $1-3$, table 4 ). The order Calanoida is represented by the only known symbiotic calanoid copepod Ridgewayia fosshageni found associated with an actiniarian at the Atlantic coast of Panama (Humes \& Smith, 1974). The absence in the literature of any records of symbiotic harpacticoids is contradicted by the results recently obtained from samples of undescribed harpacticoids representing the family Laophontidae (see Yeom et al., 2018). Siphonostomatoid copepods of the diverse but poorly investigated family Asterocheridae and poecilostomatoid cyclopoids representing endoparasitic Corallovexiidae have the greatest diversity of associations and the highest number of host families (table 5). Asterocheridae are found living on invertebrates belonging to 22 families of cnidarians, echinoderms and sponges; Rhynchomolgidae are recorded from eight families of anthozoans and echinoderms; Corallovexiidae from five families of stony corals only. Three families (Lamippidae, Pseudanthessiidae, and Synaptiphilidae) are found associated with four host families; Macrochironidae and Nanaspididae are found with three host families; Cancerillidae and Lichomolgidae are found with two host families; seven families (Clausidiidae, Entomolepididae, Micropontiidae, Pseudocyclopidae, Sabelliphilidae, Synaptiphilidae, and Thaumatopsyllidae) are restricted to only one family of invertebrate hosts (table 5). The remarkable absence on Caribbean host corals for copepods of the families Anchimolgidae (124 species in 32 genera) and Xarifidae (96 species in 6 genera) so far only found on Indo-Pacific scleractinians (Stock, 1988), is confirmed by literature data and results of our recent sampling (Cheng et al., 2016; Hoeksema et al., 2017b; table 1). To explain this distribution a study of phylogenetic relationships of Corallovexiidae with other families of the order and the additional search for endoparasitic copepods living in Indo-Pacific stony corals is needed. This proposed study should includemethodsthatenabledissolutiononlyof soft coral tissue while the chitinous exoskeletons of microscopic crustaceans to remain intact. 
Fifty of 115 species of symbiotic copepods are mentioned in literature only once; 83 of 115 species of copepods are reported from only one species or one genus of the host. Only 13 species are reported in symbiosis with representatives of different families. Four species of copepods, the poecilostomatoids Eupolymniphilus occidentalis (fig. 1g), Hemicyclops columnaris, Pseudanthessius deficiens (fig. 1e) and the siphonostomatoid Nanaspis pollens (fig, $3 \mathrm{e}$ ) are found in symbiosis with representatives of different classes. Of these species only Hemicyclops columnaris is found associated with invertebrates representing different phyla: echinoderms, corals, sponges and arthropods. The finding on sponge and on a compound ascidian of the copepod Eupolymniphilus occidentalis (family Sabelliphilidae) typically living on tubicolous polychaetes requires additional confirmation (Kim, 2009). Only two species of copepods are reported living on different classes: Pseudanthessius deficiens is found on three species of echinoderms to holothurians and echinoids; Nanaspis pollens is found on holothurians and ophiurioids. Thus, most species of symbiotic copepods are found associated with invertebrate hosts belonging to a single genus or only one family. These finding suggest the need to study the effect of host specificity more extensively. Similar studies of host switching events may show that this phenomenon has occurred several times during in the evolution of symbiotic copepods, as it has among decapod crustacean taxa (Fransen \& Hoeksema, 2014; Brinkmann \& Fransen, 2016; García-Hernández et al., 2016; Horká et al., 2016; Hoeksema \& Fransen, 2017; Hoeksema et al., 2018). The very nature of the specificity of copepods to the host or to the group of hosts requires a thorough sampling program as well as the use of molecular methods (Ivanenko et al., 2018).

The number of copepod species found on a single host species varies from one to six. The sea cucumber Holothuria arenicola hosts six species of copepods (table 2). Three scleractinian and two holoturian species host five copepod species. The sea urchin Meoma ventricosa and the sea cucumber Actinopyga agassizii host four copepod species; three corals and one sponge host three species each; 18 host species have been recorded with two associated species of symbiotic copepods. $\mathrm{Nu}-$ merous findings of different species of symbiotic copepods on the same hosts as well as the presence on these hosts of other symbionts (shrimps, polychaetes, decapods, amphipods, fish etc.) shows little knowledge of species relationships in the symbiotic complexes (Stella et al., 2011; Hoeksema et al., 2012).

Copepod crustaceans living in symbiosis with the Caribbean reef invertebrates express diverse body shapes (cyclopiform, spherical, flattened etc.), remarkably different body sizes ranging from $0.25 \mathrm{~mm}$ (such as Collocheres lunulifer) to $4.75 \mathrm{~mm}$ (such as Corallovexia ventrospinosa), and various types of feeding apparatuses as well as host utilizations. Analysis of literature and sorting of samples shows a different, and sometimes very large number of individual copepods living on a single host. The most numerous are the poorly studied asterocherid copepods living on and in diverse sponges: in one sample on one sponge thousands of individual copepods belonging to several species (Schirl, 1973; Ivanenko \& Smurov, 1997; Ivanenko, 1998; Klinger et al., 2019; present study). The diversity, host specificity and phylogenetic relationships of these copepods with other siphonostomatoid copepods, especially species found in association with Caribbean stony corals are among the most interesting unexplored topics in coral reef ecology.

The symbiotic copepods are characterized by different ways of attachment to their host (loosely associated with or aggregating on the host's surface, tightly attached to the host 
by claw-like appendages, inducing a gall-like structure, or residing inside of intestine, body cavity, or the host tissues). They also show marked variation in the number of embryos present in the egg-sacs (from one embryo, as in Peltomyzon rostratum, to 50 embryos, as in Caribulus sculptus) or numerous embryos laid in copepod-induced galls. The symbiotic copepods have different types of lecithotrophic and planktotrophic naupliar stages, some of which, like Thaumatopsyllidae, are parasitic in the stomach of its host brittle star (fig. 2e; Hendler \& Kim, 2010).

Most of the ecological observations of the Caribbean symbiotic copepods are short comments added to the taxonomic descriptions and describe behavioral features and/or location on the host. Exceptions are the study of Ophiopsyllus reductus parasitizing on shallowwater ophiuroids (Emson \& Mladenov, 1987; Emson et al., 1985), the ecological observations of the endoparasitic copepods of the family Corallovexiidae living in stony corals (Butter, 1979; Herriott \& Immermann, 1979), the studies of the life cycle and ecology of copepods of the family Thaumatopsyllidae parasitizing living in the ophiuroids at naupliar stages and having non-feeding adult and subadult copepodid stages (Suarez-Morales \& Castellanos, 1998; Suarez-Morales \& Tovar, 2004; Hendler \& Kim, 2010; Ferrari et al., 2010; Ferrari \& von Vaupel Klein, 2019), and the experiments on calanoid copepods that were discovered in a host-specific association with only one species of actinarian (Humes \& Smith, 1974). Recent field trips to sample Caribbean symbiotic copepods lead to the discovery of new species of highly transformed gall-inducing copepods of the genus Sphaerippe (Lamippidae) causing the Multiple Purple Spot Syndrome previously found in Gorgonia ventalina (Ivanenko et al., 2017; Tracy et al., 2018).

The Caribbean symbiotic copepods are found on $47 \%$ species of scleractinians, $9 \%$ species of octocorals, $3 \%$ of echinoderms and of less than $1 \%$ species of sponges (table 7 ). They are found on $4 \%$ of potential hosts of the Caribbean invertebrates which corresponds with previous data on symbiotic copepods (Humes, 1994). The literature and samples analyses indicate a poor knowledge of the diversity and distribution of symbiotic copepods living on different hosts in various ecoregions, and a particularly poor knowledge of copepods living on corals and sponges (Boxshall \& Huys, 1994; García-Hernández et al., 2019; present study) with unknown but potentially high impact on their host and reef community (Ho, 2001; Berkenbusch \& Rowden, 2003; Hatcher et al., 2012; Shelyakin et al., 2018; Zeppilli et al., 2015, 2018).

\section{Acknowledgements}

The preparation of the database, sampling in Cuba and processing of the paper were supported by the Russian Foundation for Basic Research (grant 18-54-34007). The data on samples from St. Eustatius (2015) and Curaçao (2017) were obtained with support of a Temminck-Fellowships to VNI by Naturalis Biodiversity Center. BWH and VNI want to thank staffs of the Caribbean Netherlands Science Institute (CNSI) at St. Eustatius and the Carmabi Research Station at Curaçao for hospitality and assistance. Sorting of samples and identification of copepods were conducted with partial support of the Russian Foundation for Basic Research (grant 18-04-01192). Jaaziel Emmanuel Garcia-Hernandez (University of Puerto Rico at Mayagüez) provided identification of sponges collected during the field trips; Frank Ferrari commented on a draft of the manuscript; Maickel Armenteros (University of Havana) hosted VNI and OAK during the field trip to Cuba. 


\section{References}

Alvarado, J.J. (2011) Echinoderm diversity in the Caribbean Sea. Mar. Biodivers., 41, 261-285.

Bayer, F.M. (1961) The shallow-water Octocorallia of the West Indian region. Stud. Fauna Curaçao Caribb. Is., 12, 1-373.

Berkenbusch, K. \& Rowden, A.A. (2003) Ecosystem engineering: moving away from 'just-so' stories. New Zeal. J. Ecol., 27, 67-73.

Bongaerts, P., Ridgway, T., Sampayo, E.M. \& HoeghGuldberg, O. (2010) Assessing the "deep reef refugia" hypothesis: focus on Caribbean reefs. Coral Reefs, 29, 309-327.

Bongaerts, P., Frade, P.R., Hay, K.B., Englebert, N., Latijnhouwers, K.R.W., Bak, R.P.M., Vermeij, M.J.A. \& Hoegh-Guldberg, O. (2015) Deep down on a Caribbean reef: lower mesophotic depths harbor a specialized coralendosymbiont community. Sci. Rep., 5, 7702.

Boxshall, G.A. \& Huys, R. (1994) Asterocheres reginae, a new species of parasitic copepod (Siphonostomatoida: Asterocheridae) from a sponge in Belize. System. Parasitol., 27, 19-33.

Brinkmann, B.W. \& Fransen, C.H.J.M. (2016) Identification of a new stony coral host for the anemone shrimp Periclimenes rathbunae Schmitt, 1924 with notes on the host-use pattern. Contrib. Zool., 85, 437-456.

Butter, M.E. (1979) Biology and infestation rate of Corallonoxia longicauda, an endoparasitic copepod of the West Indian reef coral Meandrina meandrites. Bijdr. Dierk., 48, 141-155.

Carpenter, K.E., Abrar, M., Aeby, G., Aronson, R.B., Banks, S. et al. (2008) One-third of reef-building corals face elevated extinction risk from climate change and local impacts. Science, 321, $560-563$.

Carvalho, S., Curdia, J., Pereira, F., Guerra-Garcia, J.M., Santos, M.N. \& Cunha, M.R. (2014) Biodiversity patterns of epifaunal assemblages associated with the gorgonians Eunicella gazella and Leptogorgia lusitanica in response to host, space and time.J. Sea Res., 85, 37-47.
Cheng, Y.R., Meng, P.J., Mayfield, A.B. \& Dai, C.F. (2016) Copepods associated with scleractinian corals: a worldwide checklist and a case study of their impact on the reef-building coral Pocillopora damicornis (Linnaeus, 1758) (Pocilloporidae). Zootaxa, 4174, 291-345.

DeBiasse, M.B., Richards, V.P., Shivji, M.S. \& Hellberg, M.E. (2016) Shared phylogeographical breaks in a Caribbean coral reef sponge and its invertebrate commensals. J. Biogeogr., 43, 2136-2146.

Dojiri, M., Hendler, G. \& Kim, I.H. (2008) Larval development of Caribeopsyllus amphiodiae (Thaumatopsyllidae: Copepoda), an enterozoic parasite of the brittle star Amphiodia urtica. J. Crust. Biol., 28, 281-305.

Edwards, C.L. (1891) Beschreibung einiger neuen Copepoden und eines neuen copepodenähnlichen Krebses, Leuckartella paradoxa. Arch. Naturgesch., 57, 75-104.

Emson, R.H. \& Mladenov, P.V. (1987) Brittlestar host specificity and apparent host discrimination by the parasitic copepod Ophiopsyllus reductus. Parasitology, 94, 7-15.

Emson, R.H., Mladenov, P.V. \& Wilkie, I.C. (1985) Studies of the biology of the West Indian copepod Ophiopsyllus reductus (Siphonostomatoida: Cancerillidae) parasitic upon the brittlestar Ophiocomella ophiactoides. J. Nat. Hist., 19, 151-171.

Felder, D.L. \& Camp, D.K. (2009) Gulf of Mexico. Origins, Waters, and Biota. Vol. 1. Biodiversity. Texas A\&M University Press, College Station. 1393 pp.

Ferrari, F.D. \& von Vaupel Klein, J.C. (2019) Rhabdomoplea, a new superorder for the thaumatomatopsylloid copepods: the consequence of an alternative hypothesis of copepod phylogeny. Crustaceana, 92, 177-188.

Ferrari, F.D., Ivanenko, V.N. \& Dahms, H.U. (2010) Body architecture and relationships among basal copepods. J. Crust. Biol., 30, 465-477.

Fransen, C.H.J.M. \& Hoeksema, B.W. (2014) Going for the stars: extending the host record for the reef-dwelling Emperor shrimp, Periclimenes 
imperator (Pontoniinae). Mar. Biodivers., 44, 465-466.

García-Hernández, J.E., Reimer, J.D. \& Hoeksema, B.W. (2016) Sponges hosting the Zoanthariaassociated crab Platypodiella spectabilis at St. Eustatius, Dutch Caribbean. Coral Reefs, 35, 209. García-Hernández, J.E., Sanchez, P.J., Hammerman, N.M. \& Schizas, N.V. (2018) Fish, coral, and sponge assemblages associated with altiphotic and mesophotic reefs along the Guánica Biosphere Reserve continental shelf edge, Southwest Puerto Rico. Front. Mar. Sci., 5, 303.

García-Hernández, J.E., Hammerman, N.M., CruzMotta, J.J. \& Schizas, N.V. (2019) Associated organisms inhabiting the calcareous sponge Clathrina lutea in La Parguera Natural Reserve, Puerto Rico. bioRXiv, 596429. doi:10.1101/596429

Gotto, R.V. (1979) The association of copepods with marine invertebrates. Adv. Mar. Biol., 16, 1-109.

Gotto, R.V. (1993) Commensal and parasitic copepods associated with marine invertebrates (and whales). In: D.M. Kermack, R.S.K. Barnes \& J.H. Crothers (Eds) Synopses of the British Fauna (New Series), 46, pp. 1-264.

Grygier, M.J. (1980) Two new lamippid copepods parasitic on gorgonians from Hawaii in the Bahamas. Proc. Biol. Soc. Wash., 93, 662-673.

Hatcher, M.J., Dick, J.T.A. \& Dunn, A.M. (2012) Diverse effects of parasites in ecosystems: linking interdependent processes. Front. Ecol. Environ., 10, 186-194.

Hendler, G. \& Kim, I.H. (2010) Larval biology of thaumatopsyllid copepods endoparasitic in Caribbean ophiuroids. J. Crust. Biol., 30, 206-224.

Herriott, A.B. \& Immermann, F.W. (1979) A preliminary report on copepods endoparasitic in stony corals of St. Croix, U.S. Virgin Islands. Crustaceana, 36, 166-172.

Ho, J-S. (2001) Why do symbiotic copepods matter? Hydrobiologia, 453/454, 1-7.

Hoeksema, B.W. \& Cairns, S. (2019) World List of Scleractinia. Available online: http://www.marinespecies.org/scleractinia [Accessed 26 April 2019].
Hoeksema, B.W., van der Land, J., van der Meij, S.E.T., van Ofwegen, L.P., Reijnen, B.T., van Soest, R.W.M. \& de Voogd, N.J. (2011) Unforeseen importance of historical collections as baselines to determine biotic change of coral reefs: the Saba Bank case. Mar. Ecol., 32, 135-141.

Hoeksema, B.W, van der Meij, S.E.T. \& Fransen, C.H.J.M. (2012) The mushroom coral as a habitat.J. Mar. Biol. Assoc. U.K., 92, 647-663.

Hoeksema, B.W., Reimer, J.D. \& Vonk, R. (2017a) Editorial: biodiversity of Caribbean coral reefs (with a focus on the Dutch Caribbean). Mar. Biodivers., 47, 1-10.

Hoeksema, B.W., van Beusekom, M., ten Hove, H.A., Ivanenko, V.N., van der Meij, S.E.T. \& van Moorsel, G.W.N.M. (2017b) Helioseris cucullata as a host coral at St. Eustatius, Dutch Caribbean. Mar. Biodivers., 47, 71-78.

Hoeksema, B.W., Bongaerts, P. \& Baldwin, C.C. $(2017 \mathrm{c})$ High coral cover at lower mesophotic depths: a dense Agaricia community at the leeward side of Curaçao, Dutch Caribbean. Mar. Biodivers., 47, 67-70.

Hoeksema, B.W., Butôt, R., \& García-Hernández, J.E. (2018) A new host and range record for the gall crab Fungicola fagei as symbiont of the mushroom coral Lobactis scutaria at Hawai'i. Pac. Sci., 72, 251-261.

Horká, I., De Grave, S., Fransen, C.H.J.M., Petrusek, A. \& Ďuriš, Z. (2016) Multiple host switching events shape the evolution of symbiotic palaemonid shrimps (Crustacea: Decapoda). Sci Rep., 6, 26486.

Humes, A.G. (1969a) Aspidomolgus stoichactinus n. gen., n. sp. (Copepoda, Cyclopoida) associated with an actiniarian in the West Indies. Crustaceana, 16, 225-242.

Humes, A.G. (1969b) Copepods of the genus Scambicornus (Cyclopoida, Lichomolgidae) associated with holothurians in the West Indies. Stud. Fauna Curacao Caribb. Is., 29, 79-95.

Humes, A.G. (1973) Cyclopoid copepods of the genus Acanthomolgus (Lichomolgidae) associated 
with gorgonians in Bermuda. J. Nat. Hist., 7 , $85^{-115}$.

Humes, A.G. (1982) A review of Copepoda associated with sea anemones and anemone-like forms (Cnidaria, Anthozoa). Trans. Am. Philosoph. Soc. Phil., 72, 1-120.

Humes, A.G. (1984) Hemicyclops columnaris sp. n. (Copepoda, Poecilostomatoida, Clausidiidae) associated with a coral in Panama (Pacific side). Zool. Scr., 13, 33-39.

Humes, A.G. (1985) Cnidarians and copepods: a success story. Trans. Am. Microsc. Soc., 104, 313-320.

Humes, A.G. (1994) How many copepods? Hydrobiologia, 292, 1-7.

Humes, A.G. (1998) Copepoda (Siphonostomatoida) associated with Ophiuroidea in Jamaica, Puerto Rico and Barbados. Zool. Verh., 323, $365-382$.

Humes, A.G. (2000) Asterocheres crinoidicola n. sp., a copepod (Siphonostomatoida: Asterocheridae) parasitic on crinoids in Belize. Syst. Parasitol., 47, 103-110.

Humes, A.G. \& Goenaga, C. (1978) Calonastes imparipes, new genus, new species (Copepoda, Cyclopoida), associated with the antipatharian coral genus Stichopathes in Puerto Rico. Bull. Mar. Sci., 28, 189-197.

Humes, A.G. \& Hendler, G. (1972) New cyclopoid copepods associated with the ophiuroid genus Amphioplus on the eastern coast of the United States. Trans. Am. Microsc. Soc., 91, 539-555.

Humes, A.G. \& Hendler, G. (1999) Biology and taxonomy of species of Ophiopsyllus and Pseudanthessius (Copepoda) associated with brittle stars (Ophiuroidea) in Belize. Bull. Mar. Sci., 65, 699-713.

Humes, A.G. \& Ho, J.S. (1970) The genus Diogenella (Copepoda, Cyclopoida) parasitic in holothurians in the West Indies. Crustaceana, 19, 15-36.

Humes, A.G. \& Ho, J.S. (1971) The genus Diogenidium (Copepoda, Cyclopoida) parasitic in holothurians in the West Indies. Crustaceana, 20, 171-191.
Humes, A.G. \& Stock, J.H. (1973) A revision of the family Lichomolgidae Kossmann, 1877, cyclopoid copepods mainly associated with marine invertebrates. Smiths. Contr. Zool., 127, 1-368.

Humes, A.G. \& Smith, W.L. (1974) Ridgewayia fosshageni $\mathrm{n}$. sp. (Copepoda, Calanoida) associated with an actiniarian in Panama, with observations on the nature of the association. Caribb. J. Sci., 14, 125-139.

Hughes, T.P., Barnes, M.L., Bellwood, D.R., Cinner, J.E., Cumming, G.S. et al. (2017) Coral reefs in the Anthropocene. Nature, 546, 82-90.

Ivanenko, V.N. (1998) Laperocheres koorius, a new genus and species (Copepoda: Siphonostomatoida: Asterocheridae) associated with the sponge Amphimedon in Australia. Proc. Biol. Soc. Wash., 111, 263-271.

Ivanenko, V.N. (2016) Symbiotic copepods associated with invertebrates at St. Eustatius. In: B.W. Hoeksema (Ed.) Marine Biodiversity Survey of St. Eustatius, Dutch Caribbean, 2015, pp. 6o-66. Naturalis Biodiversity Center, Leiden, and ANEMOON Foundation, Bennebroek.

Ivanenko, V.N., Nikitin, M.A. \& Hoeksema, B.W. (2017) Multiple purple spots in the Caribbean sea fan Gorgonia ventalina caused by parasitic copepods at St. Eustatius, Dutch Caribbean. Mar. Biodivers., 47, 79-80.

Ivanenko, V.N., Hoeksema, B.W., Mudrova, S.V., Nikitin, M.A., Martínez, A., Rimskaya-Korsakova, N.N., Berumen, M.L. \& Fontaneto, D. (2018) Lack of host specificity of copepod crustaceans associated with mushroom corals in the Red Sea. Mol. Phylogenet. Evol., 127, 770-780.

Ivanenko, V.N. \& Smurov, A.V. (1997) Asterocheres flustrae n. sp. (Copepoda: Siphonostomatoida: Asterocheridae) associated with Flustra foliacea L. (Bryozoa) from the White Sea. Syst. Parasitol., 38, 111-130.

Jossart, Q., De Ridder, C., Lessios, H.A., Bauwens, M., Motreuil, S., Rigaud, T., Wattier, R.A. \& David, B. (2017) Highly contrasted population genetic structures in a host-parasite pair in the Caribbean Sea. Ecol. Evol. 7: 9267-9280. 
Kim, I.H. (2009) Poecilostome copepods (Crustacea: Cyclopoida) associated with marine invertebrates from tropical waters. Kor. J. Syst. Zool. Spec. Issue, 7, 1-9o.

Kim, I.H. (2010) Siphonostomatoid Copepoda (Crustacea) associated with invertebrates from tropical waters. Kor. J. Syst. Zool. Spec. Issue, 8: 1-176.

Kinder, T.H., Heburn, G.W. \& Green, A.W. (1985) Some aspects of the Caribbean circulation. Mar. Geol., 68, 25-52.

Klinger, C., Żółtowska-Aksamitowska, S., Wysokowski, M., Tsurkan, M.V., Galli, R., Petrenko, I., Machałowski, T., Ereskovsky, A., Martinović, R., Muzychka, L., Smolii, O.B., Bechmann, N., Ivanenko, V., Schupp, P.J., Jesionowski, T., Giovine, M., Joseph, Y., Bornstein, S.R., Voronkina, A. \& Ehrlich, H. (2019) Express method for isolation of ready-to-use $3^{\mathrm{D}}$ chitin scaffolds from Aplysina archeri (Aplysineidae: Verongiida) Demosponge. Mar. Drugs, 17, 131.

Korzhavina, O.A., Ivanenko, V.N. (2019) Copepoda Associated with Caribbean Reef-Dwelling Cnidarians, Echinoderms and Sponges. Lomonosov Moscow State University. Occurrence dataset: https://doi.org/10.15468/qlseki [Accessed via GBIF.org 28 June 2019].

Loh, T.L. \& Pawlik, J.R. (2014) Chemical defenses and resource trade-offs structure sponge communities on Caribbean coral reefs. Proc. Nat. Acad. Sci. USA, 111, 4151-4156.

Miloslavich, P, Dhaz, J.M., Klein, E., Alvarado, J.J., Dhaz, C., et al. (2010) Marine biodiversity in the Caribbean: Regional estimates and distribution patterns. PLoS ONE, 5 , el1916.

Ortiz, M., Lalana, R. \& Figueroa, L. (1998) La presencia de Aspidomolgus stoichactinus Humes, 1969 (Copepoda, Cyclopoida), en Cuba. Avicennia, 8, 161-162.

Pawson, D.L., Vance, D.J., Messing, C.G., SolhsMarhn, F.A. \& Mah, C.L. (2009) Echinodermata of the Gulf of Mexico. In: D.L. Felder \& D.K. Camp (Eds] 1177-1204, Gulf of Mexico: Origin,
Waters, and Biota. Vol. 1. Biodiversity. Texas A\&M University Press, College Station.

Perez, T, Dhaz, M.C., Ruiz, C., Cyndor-Lujan, B., Klautau, M., Hajdu, E. et al. (2017) How a collaborative integrated taxonomic effort has trained new spongiologists and improved knowledge of Martinique Island (French Antilles, eastern Caribbean Sea) marine biodiversity. PLoS ONE, 12, e0173859.

Rivera-Monroy, V.H., Twilley, R.R., Bone, D., Childers, D.L., Coronado-Molina, R.C. et al. (2004) A conceptual framework to develop long-term ecological research and mangement objectives in the wider Caribbean region. Bioscience, $54,843^{-856 .}$

Roberts, C., Mcclean, C., Veron, J., Hawkins, J., Allen, G. et al. (2002) Marine biodiversity hotspots and conservation priorities for tropical reefs. Science, 295, 1280-1284.

Rocha, L.A., Aleixo, A., Allen, G., Almeda, F., Baldwin, C.C. et al. (2014) Specimen collection: an essential tool. Science, 344, 815-816.

Schirl, K. (1973) Cyclopoida Siphonostoma (Crustacea) von Banyuls (Frankreich, Pyrénées-Orientales) mit besonderer Berücksichtigung des Gast-Wirtverhältnisses. Bijdr. Dierk., 43, 64-92.

Scott, P.J.B. (1987) Associations between corals and macro-infaunal invertebrates in Jamaica, with a list of Caribbean and Atlantic coral associates. Bull. Mar. Sci., 40, 271-286.

Shelyakin, PV, Garushyants, S.K., Nikitin, M.A., Mudrova, S.V., Berumen, M., Speksnijder, A.G.C.L., Hoeksema, B.W., Fontaneto, D., Gelfand, M.S. \& Ivanenko, V.N. (2018) Microbiomes of gallinducing copepod crustaceans from the corals Stylophora pistillata (Scleractinia) and Gorgonia ventalina (Alcyonacea).Sci.Rep., 8,11563.

Spalding, M.D., Fox, H.E., Allen, G.R., Davidson, N., Ferdaña, Z.A. et al. (2007) Marine ecoregions of the world: a bioregionalization of coastal and shelf areas. Bioscience, $57,573-583$.

Stella,J.S., Pratchett, M.S.,Hutchings, P.A.,Jones, G.P. (2011) Coral associated invertebrates: diversity, 
ecological importance and vulnerability to disturbance. Oceanogr. Mar. Biol. Ann. Rev., 49, 43-104.

Stock, J.H. (1968) Copepoda endoparasitic of tropical holothurians. Bull. Zool. Mus. Univ. Amster. 1, 89-105.

Stock, J.H. (1973) Copepoda of the family Lamippidae from the western Atlantic and Caribbean. Stud. Fauna Curaçao Caribb. Is., 43, 22-41.

Stock, J.H. (1975a) Corallovexiidae, a new family of transformed copepods endoparasitic in reef corals, with two new genera and ten new species from Curaçao. Stud. Fauna Curaçao Caribb. Is., $47,1-45$.

Stock, J.H. (1975b) Copepoda associated with West Indian Actiniaria and Corallimorpharia. Stud. Fauna Curaçao Caribb. Is., 48, 88-118.

Stock, J.H. (1975c) On twelve species of the genus Acanthomolgus (Copepoda Cyclopoida: Lichomogidae) associated with West Indian octocorals. Bijdr. Dierk., 45, 237-269.

Stock, J.H. (1975d) Peltomyzon rostratum n. gen., n. sp., a siphonostome cyclopoid copepod associated with the West Indian coral Montastrea. Bull. Zool. Mus. Univ. Amster., 4, 111-117.

Stock, J.H. (1978) Magnippe caputmedusae n. gen., n. sp. (Copepoda: Lamippidae), a highly transformed endoparasite in octocorals of the genus Thesea from the Gulf of Mexico. Mem. Hourgl. Cruises, 3, 1-11.

Stock, J.H. (1979) A new species of Linaresia (Copepoda: Lamippidae) endoparasitic in the octocoral Placogorgia from the Gulf of Mexico. Mem. Hourgl. Cruises, 5, 1-7.

Stock, J.H. (1987) Copepoda Siphonostomatoida associated with West Indian hermatypic corals 1: Associates of Scleractinia: Faviinae. Bull. Mar. Sci., 40, 464-483.

Stock, J.H. (1988) Copepods associated with reef corals: a comparison between the Atlantic and the Pacific. Copepods associated with reef corals: a comparison between the Atlantic and the Pacific. Hydrobiologia, 167-168, 545-547.
Stock, J.H. (1989) Copepoda Siphonostomatoida associated with West Indian hermatypic corals. 2. Associates of Scleractinia: Montastreinae and Trochosmiliidae. Studies in Honour of Dr. Pieter Wagenaar Hummelinck. Uitgaven Naturwetenschappelijke Studiekring voor Suriname en de Nederlandse Antillen 123, 145-169.

Stock, J.H. (1992a) A new species of Hemicyclops (Crustacea,Copepoda, Poecilostomatoida, Clausidiidae) associated with hermit crabs in Curacao. Stud. Fauna Curaçao Caribb. Is., 71, 69-78.

Stock, J.H. (1992b) Entomolepididae (Copepoda, Siphonostomatoida) from the Antilles. Stud. Fauna Curaçao Caribb. Is., 71, 53-68.

Stock, J.H. \& Gooding, R.U. (1986) A new siphonostomatoid copepod associated with the West Indian sea urchin, Diadema antillarum. Bull. Mar. Sci., 39, 102-109.

Stock, J.H. \& Humes, A.G. (1995) Copepoda associated with Echinoidea from the West Indies. Stud. Fauna Curaçao Caribb. Is., 72, 25-46.

Stock, J.H., Humes, A.G. \& Gooding, R.U. (1962) Copepoda associated with West Indian invertebrates - I. The genus Nanaspis (Siphonostomata, Nanaspidae). Stud. Fauna Curaçao Caribb. Is., 13, 1-20.

Stock, J.H., Humes, A.G. \& Gooding, R.U. (1963a) Copepoda associated with West Indian invertebrates - II. Cancerillidae, Micropontonidae (Siphonostoma). Stud. Fauna Curaçao Caribb. Is., $15,1-23$.

Stock, J.H., Humes, A.G. \& Gooding, R.U. (1963b) Copepods associated with West Indian invertebrates - IVThe genera Octopicola, Pseudanthessius and Meomicola (Cyclopoida, Lichomolgidae). Stud. Fauna Curaçao Caribb. Is., 18, 1-74.

Suarez-Morales, E. \& Castellanos, I.A. (1998) Caribeopsyllus chawayi, new genus, new species (Copepoda: Cyclopoida: Thaumatopsyllidae), from a Mexican reef area. J. Crust. Biol., 18, 199-204.

Suarez-Morales, E. \& Tovar, E. (2004) Postnaupliar stages of a thaumatopsyllid copepod from a 
reef area of the western Caribbean Sea. Sarsia, 89, 223-244.

Terron-Sigler, A., Penalver-Duque, P., Leon-Muez, D., Espinosa Torre, F. (2014) Spatio-temporal macrofaunal assemblages associated with the endangered orange coral Astroides calycularis (Scleractinia: Dendrophylliidae). Aquat. Biol., 21, 143-154.

Tracy, A.M., Weil, E. \& Harvell, C.D. (2018) Octocoral co-infection as a balance between host immunity and host environment. Oecologia, 186, 743-753.

van der Meij, S.E.T., van Tienderen, K.M., and Hoeksema, B.W. (2015) A mesophotic record of the gall crab Opecarcinus hypostegus from a Curaçaoan reef. Bull. Mar. Sci., 91, 205-206.

van Soest, R.W.M., Boury-Esnault, N., Vacelet, J., Dohrmann, M., Erpenbeck, D. et al. (2012) Global diversity of sponges (Porifera). PLoS ONE, 7 , e35105.

Varela, C. (2010a) Nueva especie de Asterocheres y primer registro para Cuba de A. crinoidicola (Copepoda: Siphonostomatoida: Asterocheridae). Rev. Cienc. Mar. Cost., 2, 53-59.

Varela, C. (2010b) Dos nuevas especies de Asterocheres Boeck, 1860 (Crustacea: Copepoda) para Cuba. Novit. Carib., 3, 36-43.

Varela, C. (2011a) Especie nueva de Hermannella (Crustacea: Copepoda), con dos nuevos registros de copépodos para Cuba. Solenodon, 9, 1-7.

Varela, C. (2011b) Una nueva especie de Orecturus Humes, 1992 (Copepoda: Siphonostomatoida: Asterocheridae) de Cuba. Rev. Cienc. Marin. Cost., 3, 1-97.

Varela, C. (2012) Tres especies nuevas de Asterocheres (Crustacea, Copepoda, Siphonostomatoida) con un nuevo registro para Cuba. Solenodon, 10, 8-22.

Varela, C. \& Lalana, R. (2007) Especie nueva de Orecturus (Crustacea: Copepoda) para Cuba. Solenodon, 6, 15-19.

Varela, C., Castellanos, S. \& L. Hernández (2008) Registros nuevos de invertebrados (Cnidaria y Crustacea) para Cuba. Cocuyo, 17, 12-14.
Varela, C., Ortiz, M. \& Lalana, R. (2003) Nuevos registros de copépodos asociados a invertebrados marinos (Poecilostomatoidea: Lichomolgoidea), en aguas cubanas. Rev. Invest. Mar., 24, 25-256.

Varela, C., Ortnz, M. \& Lalana, R. (2005a) Especie nueva de Asteropontius (Copepoda: Siphonostomatoida) para Cuba. Solenodon, 5, 6-9.

Varela, C., Ortiz, M. \& Lalana, R. (2005b) Nuevos registros de copépodos (Crustacea: Maxillopoda: Copepoda), para aguas cubanas. Rev. Invest. Mar., 26, 79-8o.

Varela, C., Ortiz, M. \& Lalana, R. (2007a) A new species of copepod of the genus Asterocheres Boeck, 1860 (Copepoda: Siphonostomatoida), from Cuban waters. Avicennia, 19, 31-36.

Varela, C., Ortiz, M. \& Lalana, R. (2007b) Especie nueva de copepodo espongicola (Copepoda: $\mathrm{Si}-$ phonostomatoida: Asterocheridae) para Cuba. Solenodon, 6, 1-7.

Veglia, A.J., Hammerman, N.H., Rivera Rosaly, C.R., Lucas, M.Q., Galindo, A., Estronza Corgosinho, P.H. \& Schizas, N.V. (2018) Characterizing population structure of coral-associated fauna from mesophotic and shallow habitats in the Caribbean. J. Mar. Biol. Assoc. U.K., 99, 619-629. doi:10.1017/Soo25315418000413

Walter, T.C. \& Boxshall G. (2019) World of Copepods database. Available online: http://www. marinespecies.org/copepoda [Accessed 5 April 2019].

WoRMS Editorial Board (2019) World Register of Marine Species. Available online: http://www. marinespecies.org at VLIZ [Accessed 22 June 2019].

Yeom, J., Nikitin, M.A., Ivanenko, V.N. \& Lee, W. (2018) A new minute ectosymbiotic harpacticoid copepod living on the sea cucumber $\mathrm{Eu}$ pentacta fraudatrix in the East/Japan Sea. PeerJ, 6, e4979.

Zea, S., Henkel, T.P. \& Pawlik, J.R. (2014) The Sponge Guide: a picture guide to Caribbean sponges. 3rd Edition. Available online: www .spongeguide.org [Accessed 6 April 2019]. 
Zeppilli, D., Leduc, D., Fontanier, C., Fontaneto, D., Fuchs, S. et al. (2018) Characteristics of meiofauna in extreme marine ecosystems: a review. Mar. Biodivers., 48, 35-71.

Zeppilli, D., Sarrazin, J., Leduc, D., Arbizu, P.M., Fontaneto, D. et al. (2015) Is the meiofauna a good indicator for climate change and anthropogenic impacts? Mar. Biodivers., 45, 505-53.

RECEIVED: 29 APRIL 2019 | REVISED AND

ACCEPTED: 2 JULY 2019

EDITOR: R.W.M. VAN SOEST 